\title{
خدمة الطباعة ثلاثية الأبعاد في المكتبات حول العالم : دراسة مسحية
}

\author{
د. مها محمد رمضان \\ مدرس بقسم المكتبات و العلومات \\ كلية الآداب، جامعة عين شمس، مصر مصر
}

جلب تكنولوجيا الطباعة ثثلاثية الأبعاد ملخص:

لمجتمعاتها، و انتهت الدراسة بمجمو عة من بدأت بعض مكتبات العالم في السنوات التوصيات، منها: ضرورة جلب هذه التكنولوجيا الخمس الأخيرة تقديم خدمة الطباعة ثناثية الجديدة وتقديم هذه الخدمة داخل المكتبات الأبعاد كخدمة تعليمية و إبداعية و ترفيهية العربية التي اختفت بين جنباتها الخدمة في

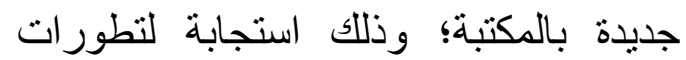
كافة الدول العربية، مع اقتر اح عدة در اسات التكنولوجيا الرقمية، وحرصًا منها على على مستقبلية للباحثين، كدراسة بيئة العمل التي تعمل من خلالها الخدمة. أولاً: مقدمة:

بدأت المكتبات على مدى السنوات المـاضية تأخذ على عاتقها توفير التكنولوجيا الرقمبية للمستفيدين منها، و التي لم تسنح لهم إمكانياته إتاحة خدمات جديدة للمستفيدين يصعب

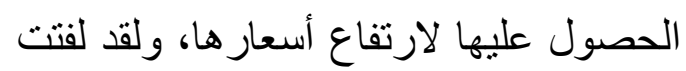
هذه الخدمة نظر الباحثة فعدد إلى عمل در اسة مسحية شاملة للمكتبات التي تقدم هذه الخدمة، بهدف التعرف على طبيعة هذه مذه مله الخدمة الجديدة، وكذلك بيئة العمل التي المادية أو الفنية الحصول على هذه التكنولوجيا احتضنت الخدمة، وما رصدته من ميز انيات في منازلهم وبالتالي توفير ها لهح دون أبـه قيود وما أتاحته من برامج وأجهزة وتدريب تذكر، واتضحت تللك المهمـة جليًا منذ بدايـة للموظفين و المستفيدين لاستقبال الخدمة، ووما توفير الإنترنت والأجهزة و البر امـج مرتفعة وضعته من سياسات للاستخدام، و استخدمت الأسـعـار، ثم تـوفير الاشتـر الك في مصسادر الدراسة لذلك المنهج المسحي، وقائمة المعلومات الإلكترونية المختلفة وغيرهـا، مراجعة لجمع المادة العلمية وتحليل ليتبلور أحد أهداف ومهام المكتبات في الالتزام المضمون، وكثفت الدراسة: عن أن هذه بسد ثغر ات الحصول على التكنولوجيا الحديثة الخدمة تقدمها سجا مكتبة على مستوي داخل المجتمع، ثم مشار كتها للجميع مما يضــن العالم، جاءت مكتبات الولايات المتحدة على المساو اة في الاقتناء و الاستخدام. رأسها، وأن المكتبات العامة كانت في طليعة 
في الدكتبات حول العالم التي أدخلت هذا النوع الجديد من الطباعة. ثنايتًا: مشكلة الدراسة وتساؤلاتها: سمح توفير خدمة الطباعة ثلاثيـة الأبعاد في نحو ب7 أمكتبة حول العالم، في تحول دور المكتبة من توفير الوصول للمعلومات

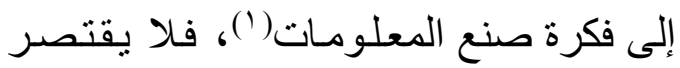
دور المكتبة فقط على الاقتناء والحفظ، وإنما

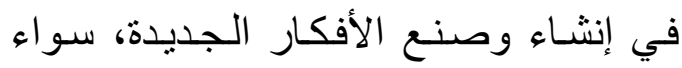

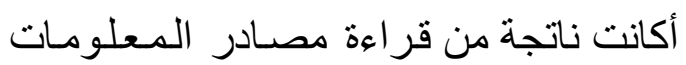

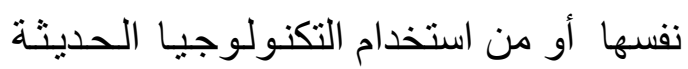
بتطبيقاتها المختلفة، والتي من ضمنها

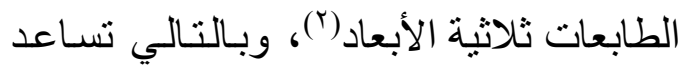

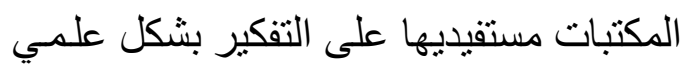
وعملي فيمكنه التعلم من خلال التجريب و الممارسة عن طريق نشاط وخدمات جديدة

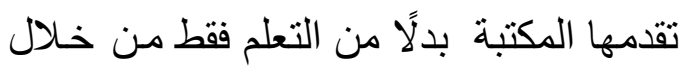

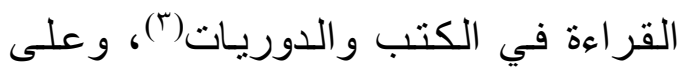
الرغم من تبني تللك الرؤية في كثير من التبن المكتبات الأجنبية التي وفرت الخدمة، نجد غيابًا و اضحًا لتبني تللك الرؤية وهذه الخدمة

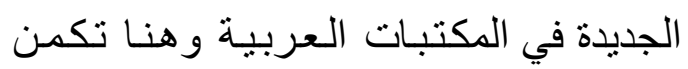

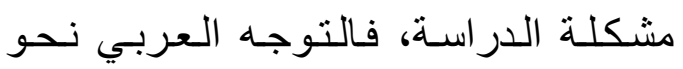

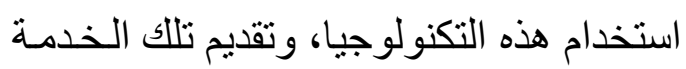
للمستفيدين في المكتبات العربية اختفي

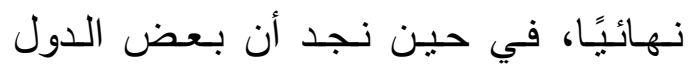
كالو لايات المتحدة تعلن أن نسب استخدام
ومن هنا لم تكن فكرة إدخال خدمة

الطباعة ثلاثية الأبعاد في المكتبات الأجنبية

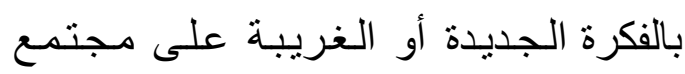
المكتبات هناك، وبالتالي فقد استقبلت المكتبات في العالم المتقدم هذه الخدمة

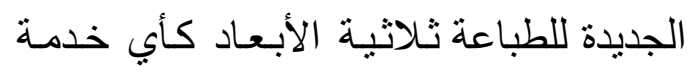

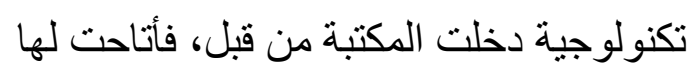

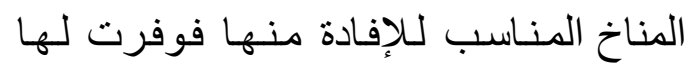

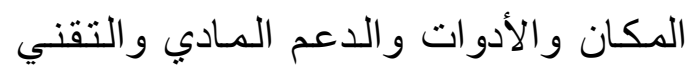
والبشري للاستفادة منها بالثكل الأمثل. وكان دأب المكتبات الأجنبية في تقديم

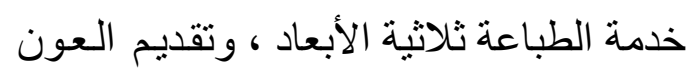

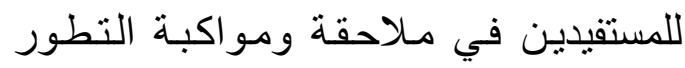

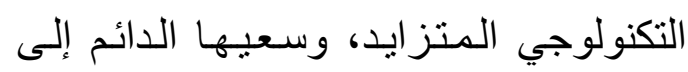

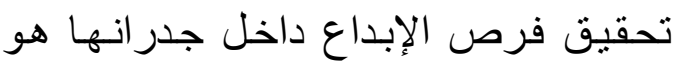

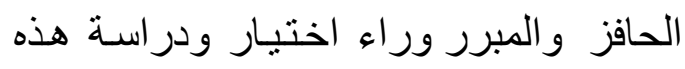
الظاهرة الجديدة داخل هذه المكتبات حول ولئل العالم ودر اسة متطلباتها الفنيـة والمالية و البشرية، ومن ثم محاولة إدخالها بالمكتبات

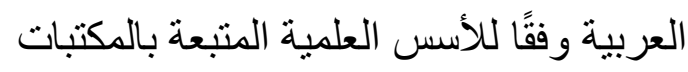
الأجنبية وخاصـة في ظل غياب الكتابات

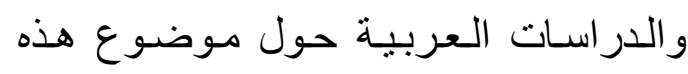
الخدمة برمتها، سواء من الجانب النظري للخدمة ومتطلباتها أم من الجانب التطبيقي

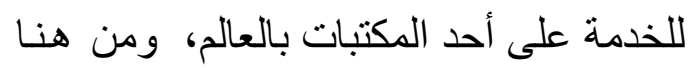

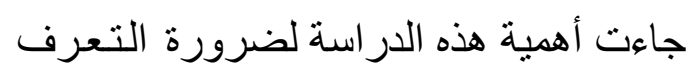
على طبيعة الخدمة بشقيها النظري و التطبيقي 
داخل المكتبات؟

و - ما أنواع المكتبـات محل الدر اسـة التي

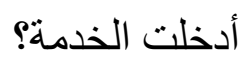

ز ـ ما مدى توفير المكتبات محل الدراسـة

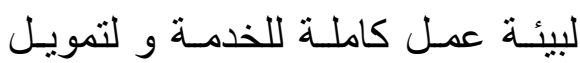

$$
\text { مناسب لها؟ }
$$

ح- كيف قامـت المكتبـات محل الدراسـة بعملية التدريب لموظفيها ومتردديها؟

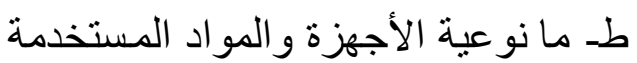

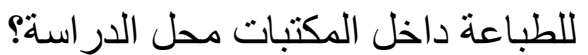
ى- كيف تبدو السياسـات الحاكمـة لإدارة العمل داخل المكتبـات التي تقدم هذه

الخدمة:

ثنالثًا: أهداف الدراسة: تهرف هذه الار اسة إلى: ا ـ التعرف على خدمة الطباعة ثلاثية الأبعاد

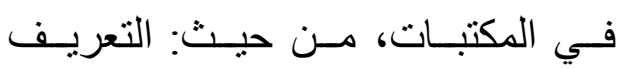

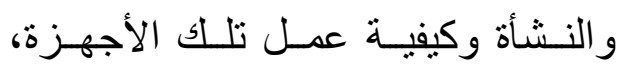
و أنو اعها، وأسعار ها، وشكل البيئة التي وهي

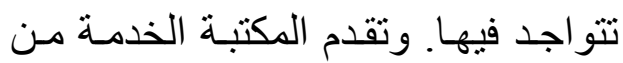
خلالها للمستفيدين. r- در اسة تجربة بعض البلدان الأجنبيـة في تطبيق خدمة الطباعة ثناثية الأبعاد داخل مكتباتها. r- وضع أسس علميـة لسياسـة عربيـة تحكم

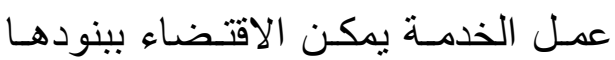
داخل المكتبات بالعالم العربي.
الطـابــات ثـلاثيـة الأبعـاد في مكتبـات

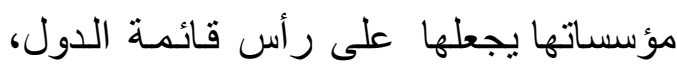

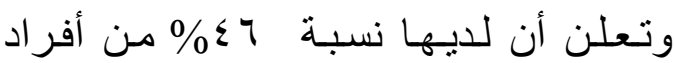

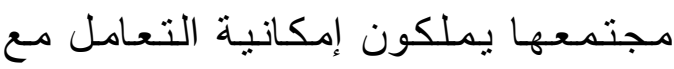

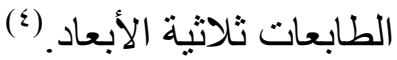
ومن ثم كانت الحاجة العلمبـة لتواجد مثنل هذه الدراسة ؛ للتعرف على واقع هذه الخدمـة في المكتبـات بالعـالم وكيفيـة تقديمها للجمهور وما السياسات المقننة لها، ومـا المتطلبـات الماليـة و التقنية و البشرية و التجهيزيـة اللازمـة لاستقبال

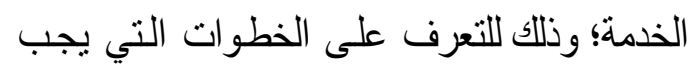
على المكتبات في العالم العربي مر اعاتها عند البداء في التفكير في إدخال الخدمـة؛ ولتقديـم خارطة طريق تضمن المسار الصحيح والأسس الصس التي يمكن أن تتبناهـا المكتبـات العربيـة التي في تريــ تقديم الخدمـة والاسـتفادة مـن مميزاتهـا وتطبيقاتها لمستفيديها؛ ولذللك تسعي الدراسـة ولته للإجابة على التساؤلات التالية:

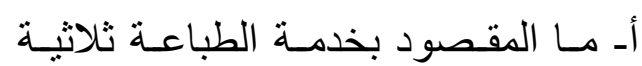

$$
\text { الأبعاد؟ }
$$

بـ مـتى نـشأت خدمـة الطباعـة ثلاثيـة الأبعاد داخل المكتبات؟

ج- كيفية عمل الطابعات ثلاثية الأبعاد؟ دـ ما الاحتياجـات الفنية و المالية اللازمـة لإدخال تللك الخدمة داخل المكتبات؟ هـ ما طبيعة محتويات منطقة العمل التي تتو افر بها خدمة الطباعة ثلاثبة الأبعاد 
حول العالم، دون النظر إلى فئاتها الجغر افية ومكان نشأتها أو تو اجدها. عـ الحدود اللغوية:

تتناول الدر اسة المكتبات التي تقدم الخدمـة و أعلنت عن بياناتها على الإنترنت باللغتين

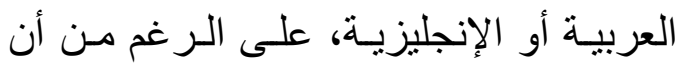
بعض المكتبات التي حصرتها الباحثة كانت لمكتبـات فرنسية وصـينية و ألمانيـة إلا أنها أعلنت عن الخدمـة على مو اقعها بـأكثر من ون لغة، كانت من بينها اللغة الإنجليزية. خامسًا: منهج الدراسة وأدواتها: ا ـ منهج الدراسة المتبع: تعتمد الدر اسة على المنهج المسحي الذي يرمي إلى در اسة الظو اهر الجديدة في مجتمع معين، فالدر اسـة استعرضت واقع حـال أحد الخدمات الجديدة التي ظهرت في مجتمـع المكتبات، وفرضت نفسها عليه كخدمة جديدة يجب أن توفر هـا المكتبـات لمتردديها؛ حيث تقوم الباحثة في الجزء العملي من الدراسـة بالتعرف على واقع حال خدمة الطباعة ثلاثية الأبعـاد في المكتبـات الأجنبيـة حول العـالم، وذلك للخروج منها بـالخطوات التي يجب التبا. على المكتبـات في العـالم العربي مر اعاتها عند البدء في التفكير في إدخال الخدمة.

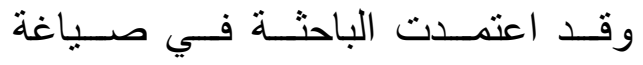
الاستـشهادات المرجعيــة بالدر اســـة علـى لـى البرنامج الآلي EndNote ${ }^{\circ x}$ عن طريق

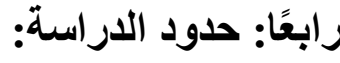
تتمثنل حدود الدراسـة في أربعـة أنـواع مـن الحدود هي: - (الحي 1ـ الحدود الموضوعية : يقتصر موضـوع الدر اســة على در اســة خدمـة الطباعـة ثلاثيـة الأبعـاد حـول العـالم؛ مؤه وذلك مـن خـلال: در اسـة التعريـف و النـشأة

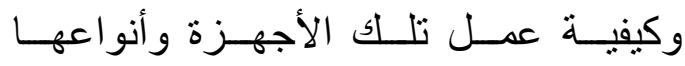
وأسـعار ها، ثم التعـرف على طبيعـة الخدمـة داخل جميع المكتبات الأجنبيـة التي أتاحتها ولخصائص البيئة التي تنو اجد فيها، و لكيفية

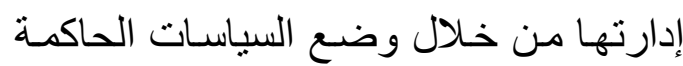
و التمويل المناسب، شرط أن تكون قد أعلنت المكتبـات عن تقديمها للخدمـة على مو اقعها الإلكترونية؛ حتى يتسنى للباحثة جمع مادتها العلمية من تللك المو اقع وتحليل بياناتها. r- الحدود الزمنية:

تتاولت الدر اسة المكتبات التي تقدم خدمـة الطباعـة ثلاثيــة الأبعـاد داخـل جـدر انها، و أعلنت ذللك على مو اقعها الإلكترونية، وذلك على امتداد عام كامل بدايته مـن شـهر يونيو

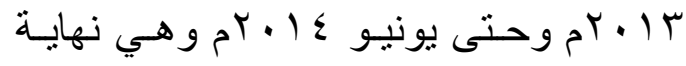
حصر الباحثة للمكتبات ؛ لتتمكن بعد ذلك من البدء في تحليل البيانات. rـ الحدود المكاتية: تتناول الدر اسة المكتبات التي تقدم خدمـة الطباعة ثنلاثية الأبعاد في المكتبـات الأجنيية 
محركـات البحـث وبعـدها مـن تحليـل جميـع المعلومات الخاصـة بالخدمة و اللازمـة لاستكمال

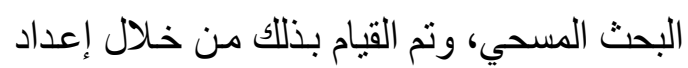

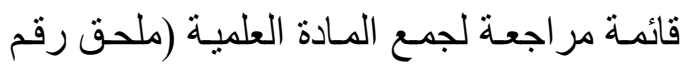

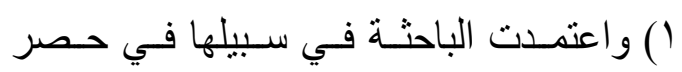
مجتمع الدر اسة على طريقتين، هما:

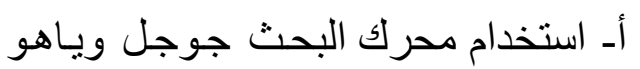
في مسح شبكة الإنترنت؛ وذلك من خلال استخدام استراتيجيـات بحث مختلفة تصل إلى ( • ع إستر اتيجية بحث) بـاللغتين الإنجليزيـة واللغنة العربية؛ حيث قسمت استر اتيجباتهـا بهابها إلى ثلاثة أقسـام، (انظر الجدول رقم
استخدام صياغة APA $7^{\text {th }}$ Edition. r - مجتمع الدراسة:

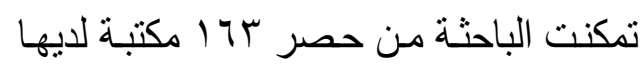

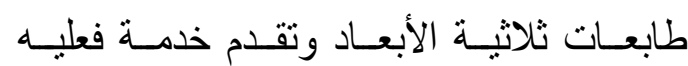
للطباعـة للمستفيدين منهـا ( الملحـق رقـم ب)، وطبقت الدراسـة على جميع هذه المكتبـات التي

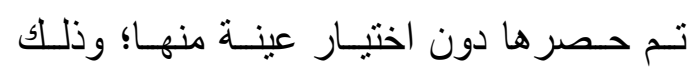

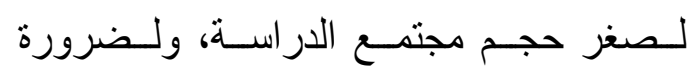

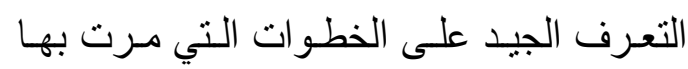
هذه الخدمة بالمكتبات؛ وذلك للاستفادة منها عند

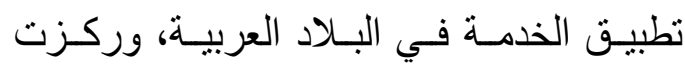
الباحثة في حصر ها على المكتبات التي أعلنت عن تو افر الخدمـة لديها عبر شبكة الإنترنتـ؛

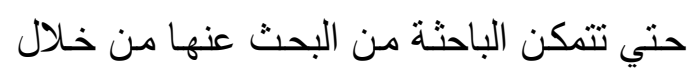

جدول (1) استراتيجيات البحث المستخدمة لحصر المكتبات باللغتين العربية والإنجليزية

\begin{tabular}{|c|c|c|}
\hline استراتيجيات بحث اللغة الإنجليزية & استر اتيجيات بحث اللغة العربية & \\
\hline $\begin{array}{l}\text { 3d printing service or } 3 d \text { printer }+ \\
\text { library or public libraries or school } \\
\text { libraries or university or Special or } \\
\text { National Libraries }\end{array}$ & 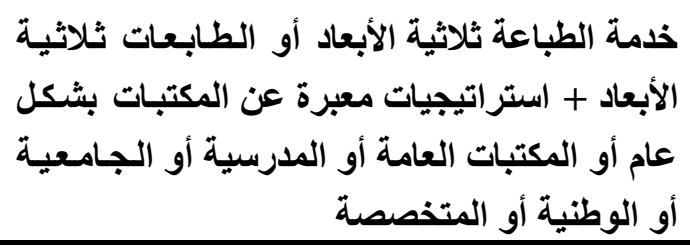 & 1 \\
\hline $\begin{array}{r}\text { policy or }+3 d \text { printing or } 3 d \text { printer } \\
\text { procedures or a guide }\end{array}$ & 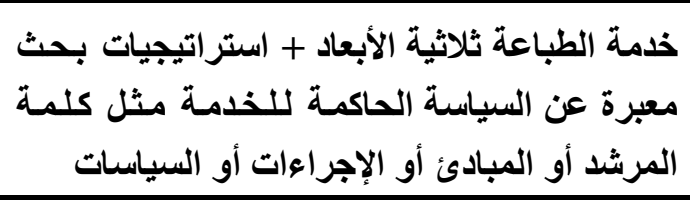 & r \\
\hline $\begin{array}{l}\text { 3d printing }+ \text { makerspace or } \\
\text { hackerspace or Create Space or } \\
\text { or or a laboratory fabrication } \\
\text { or Media or open or think or fablab } \\
\text { lab or studio innovation or learing } \\
\text { or tech room or desk or shop or } \\
\text { rD Print Centre }\end{array}$ & 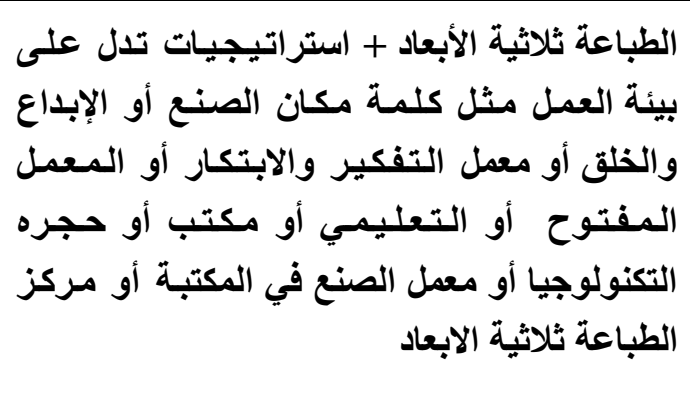 & $r$ \\
\hline
\end{tabular}


بحصر بعض المكتبات التي أدخلت ب- اعتمدت الباحثنة في حصر ها أيضًا

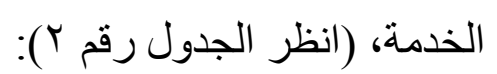

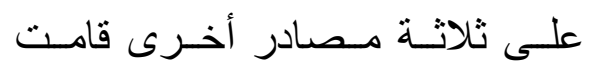

جدول (Y) المصادر المستخدمة في حصر المكتبات التي تقدم خدمة الطباعة ثلاثية الأبعاد

\begin{tabular}{|c|c|c|}
\hline أعداد المكتبات & 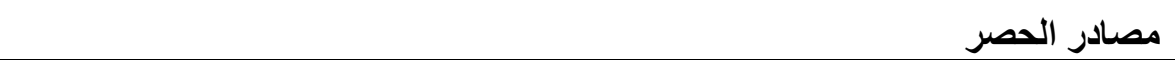 & ? \\
\hline 10 & 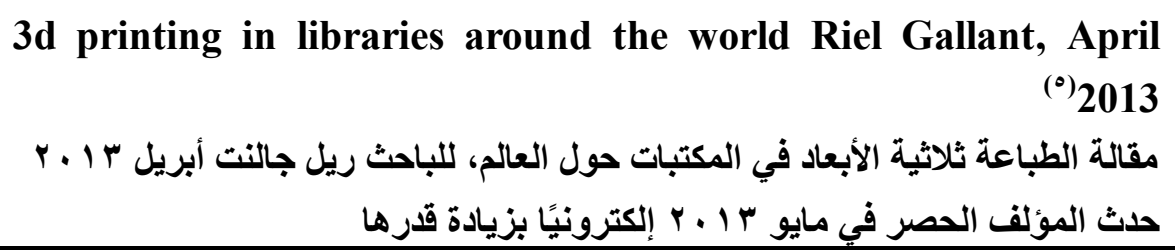 & 1 \\
\hline ع مكتبة & 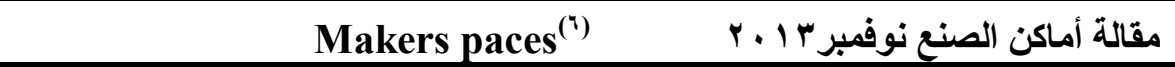 & r \\
\hline 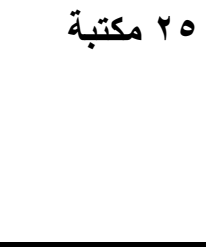 & 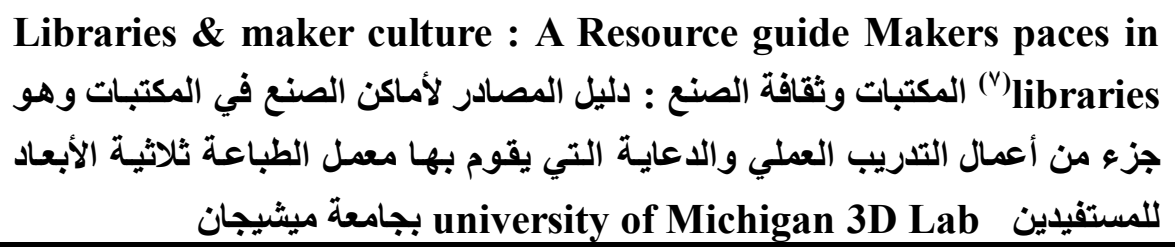 & $r$ \\
\hline ع ع ا ا مكتبة & 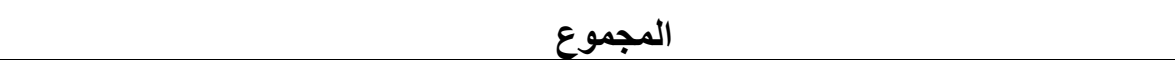 & \\
\hline
\end{tabular}

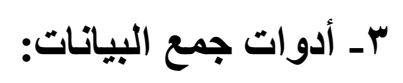

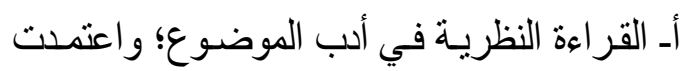
عليهـا الباحثـة في وضـــها للإطـار النظـري

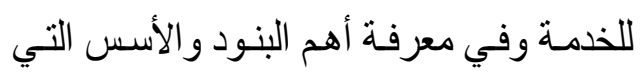

$$
\text { يجب أن تشملها قائمة المر اجعة. }
$$

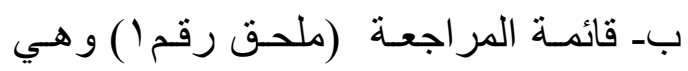

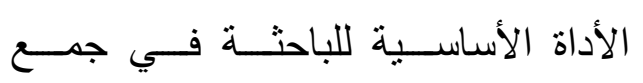

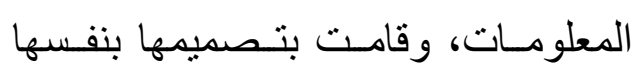

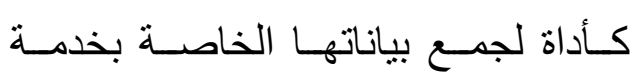

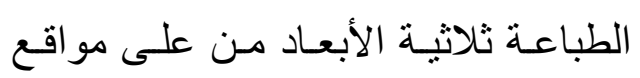

المكتبات على شبكة الإنترنت، و استفادت

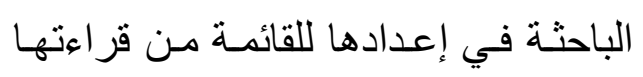

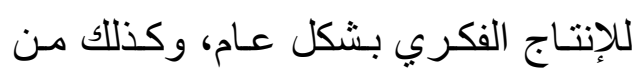

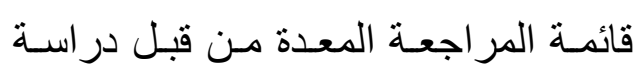

وبالطبع اشترك كل مصدر مـع غيره من المصادر التي سبقته في الحصر على عدد مكرر مـن المكتبات، وكان عدد المكتبـات

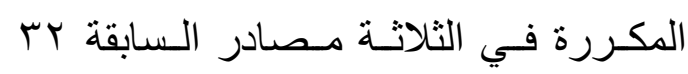

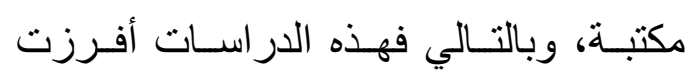
للمجتمع العلمي على عدد بو و مكتبـة أجنبية

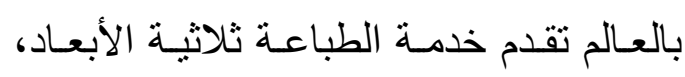
أضافت إلبها الباحثة نتيجة حصر ها ومسحها

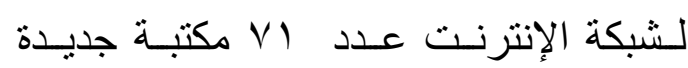

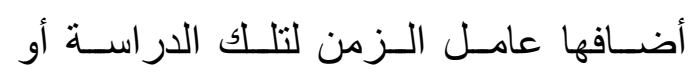
لاستخدام استر اتيجيات بحث أكثر، وبالتالي

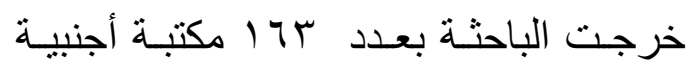
حول العالم تقدم خدمة الطباعة ثنلاثيـة الأبعاد داخل جدر انها. 
r- خدمة الطباعة ثلاثية الأبعاد (التعريف

$$
\text { الإجرائي للباحثة): }
$$

تللك الخدمة التي تقدم للجمهور من خلال المكتبة، والتي تتيح لهم إمكانية استخدام الطابعات ثثلثية الأبعاد وجميع ملحقاتها من لثن الأجهزة و البرامج الأصلية المساعدة في تصميم ملفاتهم الرقمية؛ وذللك لمساعدة متردديها في تحويل أفكار هم ومخططاتهم الرقمية إلى واقع ملموس بين أيديهم، ومساعدتهم في تحقيق التعلم من خلال الأجهزة التكنولوجية الحديثة التي يفرزها التطور التكنولوجي، وذلك و وفقًا للسياسة الحاكمة و الضابطة للخدمة داخل المكتبة.

r- أماكن الصنع Makerspace: ذلك المكان الذي يمكن لأفراد المجتمع أن يأتي فيه لتبادل الخبرات و التعاون واستكثاف وحل المشكلات، وكذلك الترفيه مع غيره من أبناء مجتمعه؛ حيث يتعامل فيه مع مهارات وبرامج وتكنولوجيا جديدة موجودة بالمكان، وبالتالي بتعلم من خلال التجريب والمشاهدة واللعب باستخدام أدوات هذا المكان، وتختلف أدوات هذا المكان من مكان لآخر، وقد يكون هذا المكان في مؤسسة أو نادي أو جامعة، وبالتالي يختلف هدفه بناءً على له له هف المؤسسة التابع لها، ويطلق على هذا المكان

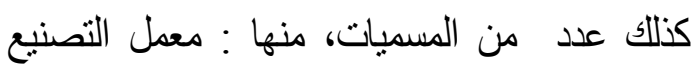

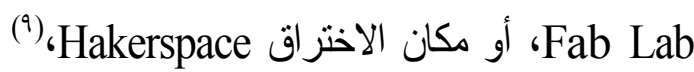
ولأن المكتبات هي أماكن ومؤسسات تعليمية
الباحـث ريــل جالنـت مiel Gallant بعنــوان الطباعـة ثلاثيــة الأبعـاد فـي المكتبات حول العالم والتي اشتملت على لـى لهي ستة بنود فقط، كانت نواة للباحثة في فكرة عملهـا وأضـافت إليهـا عـدة بنـود رأت الباحثة ضرورة إدر اجها في در استها. سادسًّا: المـصطلحات والمفـاهيم الإجرائيـة للار اسةة: ليساد: 1- الطباعة ثلاثية الأبعاد (3 D printing): هي تلك التقنية الحديثة التي فرضت نفسها في العالم كوجه جديد في ثورة التصنيع أو كثنكل من أثكال الإنتاج الصناعي في العالم، وتللك الطابعات تعمل بطريقة مشابهة جدًا لجيل الطابعات النافثة للحبر التي تقوم بطباعة ملفاتها على الورق، ولكن في هذه الطابعات الثلاثية تتم الطباعة من خلاعل إنشاء نماذج و أشكال مجسمة ثلاثية الأبعاد تحاكي وبشكل دقيق النماذج الأصلية، وذللك من خلال برامج مخصصة لذلك التصميم الرقمي ثثلاثي الأبعاد على الحاسب الآلي ليتم بعدها اعطاء أمر الطباعة لتلك الطابعات لبناء هذه النماذج طبقة فوق الأخرى باستخدام مساحيق ومواد مختلفة للتصنيع، وذلك في دقائق أو ساعات معدودة على ولى حسب حجم النموذج المطلوب طباعته ليخرج بعدها نموذج مجسم ثناثي الأبعاد بين يدي طابعيه(^). 
تتنـاول خدمـة الطباعـة ثلاثيـة الأبعـاد في المكتبـات مـن جميـع جو انبهـا، فــن خـلال لهل الدر اسة سيتم التعرف في الجزء الأول منها على إطـار نظـري لخدمـة الطباعـة ثلاثيـة الأبعـاد في المكتبـات، وفي الجـزء الثاني ستتناول الباحثة جانب تطبيقي، قـائم على العى تحليل بيانات المكتبات محل الدر اسة وتحليل نصوص سياساتها؛ للخروج بأفضل المبادئ التي تناولتها تلك المكتبات حتى نستطيع في العالم العربي وضـع خطة مكتملة العناصـر تحمي وتحفظ الحقوق للجميع، وهو مـالـم تفعلـه أيـة در اسـة عربيـة علميـة سـابقة لهذهـ وهون الدر اسة.

\section{1 ـ الدراسـات الأجنبية:}

هنالك عدد مـن الدراسـات الأجنبيـة التي

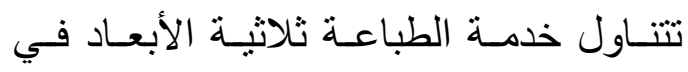
المكتبات، سو اء بشكل نظري يعرض أهميـة

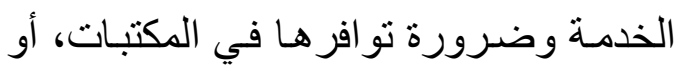
بشكل تطبيقي على حالـة فرديـة لمكتبـة أو مكتبتين تعرض طبيعة توفير الخدمة في تلك

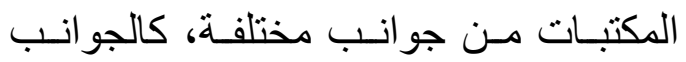
الماليـة و التقنيـة و البشرية التي يجب توفر هـا للخدمة، و هناك در اسات أخرى تثتاول منطقة

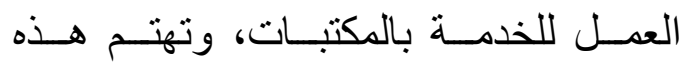
الدر اسات بـالتعريف بهذه المنطقة و أجهزتها وطبيعة عملها، ومن هذا المنطلق في تقسيم الغرب لأبحاثهم فقد رأت الباحثة عرض تلك هـ
وتثقيفية وترفيهية بتشارك فيها البشر بأفكار هم

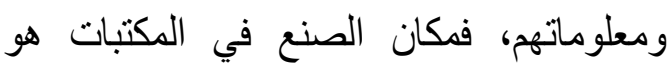
المساحة التي تخدم نفس غرض المكتبة؛ حيث يقوم فيه المستفيدون بالعمل التشاركي التعاوني فيتقاسمون الموارد و المعارف والأفكار وكذلك بلك

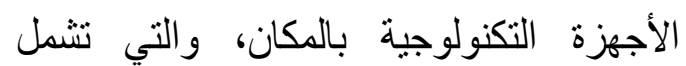
جهاز الطابعة ثناثية الأبعاد(·'). سابعًا: الاراسات السابقة والمثيلة: اعتمدت الباحثة في حصر الإنتاج الفكري السابق و المثيل للدر اسـة على أدلة الرسـائل

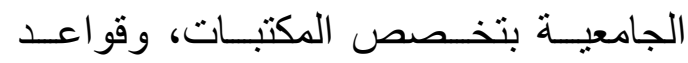

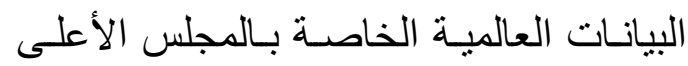
للجامعـات، و الـدوريات العربيـة و الإنجليزيـة

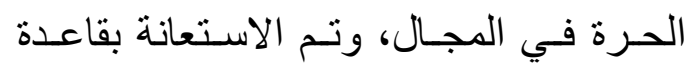
بيانـات إتاحـة الـدوريات الحـرة Doaj، ودليـل الإنتاج الفكري العربي في مجـال المكتبات

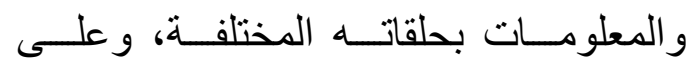
محركات البحث العالميـة، وبعد الحصر تم الرجـوع إلـى النصوص الكاملـة للأعمـال

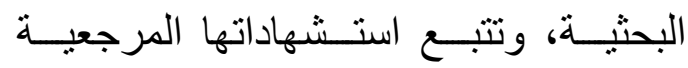
للاسـتز ادة منهـا، وبنـاءً على هـــا الحصـر الخـاص بالإنتـاج الفكري العربـي الأجنبـي

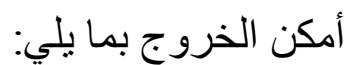
لم تجد الباحثة أيـة در اسـة عربيـة تناولت خدمة الطباعة ثلاثيـة الأبعاد و تطبيقاتها في تركي المكتبات في العالم؛ لذلك تعد الدر اسة الحاليـة أول دراسـة عربيـة على حـد علم الباحثـة 
وبإجبـار كلياتهـا بإدخـال الطباعـة ثلاثيـة الأبعـاد كجزء مـن مقرر ات در اسـة الطلاب ابتـداءً مـن الفـل الدر اسـي التـالي لـدخول خدمـة الطباعـة ثناثيـة الأبعاد في المكتبـات،

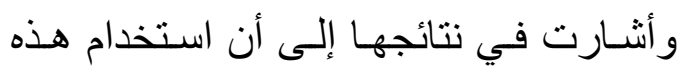
الخدمـة في الجامعـات و المكتبـات لا يتطلب تعديلات في الإجر اءات القائمـة، بل يتطلب

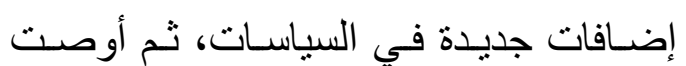
بضرورة تبني تلك الخدمـة وهذه المقررات في جميع الجامعات بالدولة.

$3 \mathrm{~d}$ printers : a revolution headed for your library ‘Betha Gutsche ,nov $2012^{\left({ }^{(r)}\right.}$

الطباعة ثلاثية الأبعاد : ثورة في مكتبتك: ركزت الدراسة على أن الطبـاعـة ثناثية الأبعاد هي عنصر هام من عناصر الثورة الصناعية، فهي تكنولوجيا تحويليـة تنقيفيـة تصنيعية، و على المكتبـات أن تؤهل نفسـها لتكون منبرًا لـهذا التحول ولهذا التصنيع لهؤيع الرقمي ولذلك بدأت الدراسة بالتعريف بـذهذه

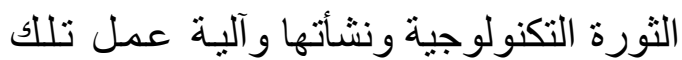

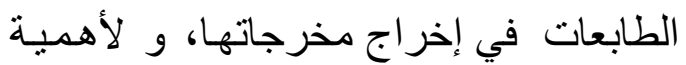
إيجادها داخل المكتبات، و انتقلت الباحثة في

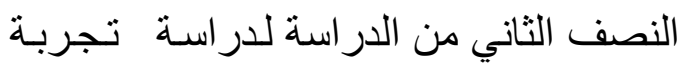
أول مكتبة قامت بإدخال خدمة الطباعة ثلاثية الأبعاد داخل جدر انها، و هي تجربـة معدل The التصنيع في المكتبة الحرة في فاتيفيل
الار اسات الأجنبية في قسمين: أــ در اسات تتناول الجانب النظري للطباعـة ثلاثية الأبعاد واستخداماتها بالإضـافة إلى تطبيــق الخدمــة فــي المكتبــات: 3d printers in the library: toward fab lab in the academic library Lisa Kurt, Tod Colegrove july, 2012 الطباعـة ثلاثبــة الأبعـاد فــي

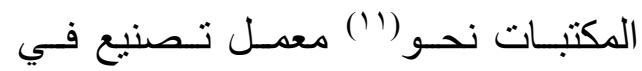
المكتبات الأكاديمية. تحدثت المقالة بشكل مفصل في الجزء الإديه. الأول منها عن تعريف خدمة الطباعة ثناثيـة الأبعـاد، وعـن أسـباب تواجـــ مثـل هـــه الخدمات داخل المكتبات الجامعية، ثم ذكرت أهم المجـالات العلميـة الجامعيـة التي يستفاد طلابهـا مـن التدريب على الطابعـات لرفع لهع

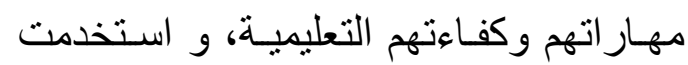
الباحثة في الجزء الثاني من در استها منهج در اسـة الحالـة لتعـرف على تجربـة جامعـة The university of Nevada نيفادا رينو Reno في إدخال خدمـة الطباعـة في مكتبـة دليمـار ، فتحدثت عن المواد المستخدمة في الطباعة و أنواع الطابعات في تلك المكتبة، وانتقلت إلى تعريف القارئ بالبر امج الداعمـة

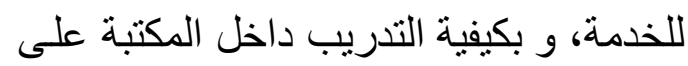
استخدام الطابعات، وفي نهايـة بحثها أشـادت

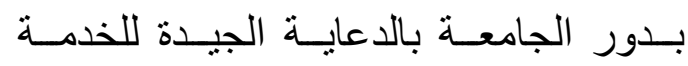


والتجهيزية، ثم عرض نتائج مفصلة ومدعمة

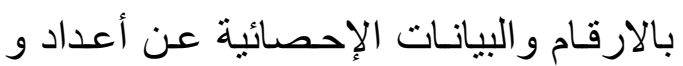

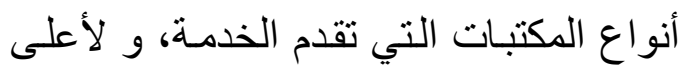
الدول و الو لايات التي تقدم الخدمـة ؛ موضـحًا أسباب تفوق تلك الولايـات عن غيرهـا، ثم ذكر أكثر أنواع الطابعـات شيو عًا، و المواد المستخدمة في المكتبات موضحًا أسباب ذلك الاسـتخدام، ثم عرض في النهايـة لأعداد المكتبـات الـتي وفـرت بيئـة عمـل مناسـبة للخدمـة، و تلك التي قدمت سياسـات حاكمـة

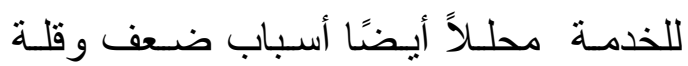
أعـداد هـذه المكتبـات، و انتهـي بتوصـيات، أهمهـا : ضـرورة جلب الخدمـة في جميـع

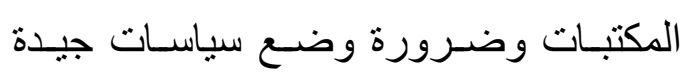
للخدمة. ب- دراسات تتناول بيئة العمل التي تتواجد فيها الطابعات ثثلاثية الأبعاد:

Makerspaces Move into Academic Libraries. Erin Fisher ‘Nov 28, $2012^{\left({ }^{(£)}\right.}$ أماكن الصنع تنتقل إلى المكتبات الأكاديمية: أشنارت الدراسـة إلى عنصـر واحلى من عناصر خدمة الطباعـة ثناثية الأبعاد في المكتبات، وهي بيئة العمل التي تتو اجد فيهـا

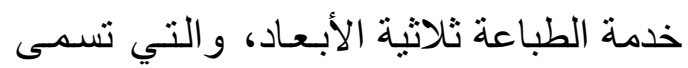
أماكن الصنع و أنها مساحات خلقت للإبداع و الصنع و الابتكار في المكتبـات، و أشـارت الدر اسة إلى تعريف مفصل لهذه المسـاحات
Fayetteville free library لذللك منهج دراسـة الحالة و اعتمدت على ولى توزيع استبيانًا إلكترونيًا للتعرف دله على رأي المستفيدين من هذه الخدمـة وفي الدروس المجانية التي تقدمها المكتبـة، وخرجت

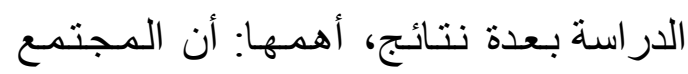
العلمي لن يستغرب في المستقبل القريب عندما يرى منتجات عليها شـعار صنّع في لهي المكتبة وبالتالي يجبب إيجاد مكان في كل ئل المكتبات لثقافة الصنع بـها، 3d printing in Riel , libraries around the world ${ }^{(1)}$ Gallant, April 2013 الطباعـة ثلاثيـة الأبعـاد في المكتبـات حول

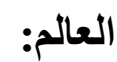

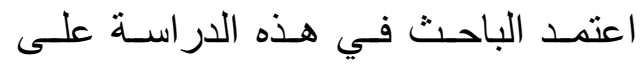
المنهج المسحي؛ حيث قام بحصر اله مكتبـة في العالم أدخلت خدمة الطباعة ثلاثية الأبعاد داخل جدر انها حتى إبريل با ب ب م؛ وذللك

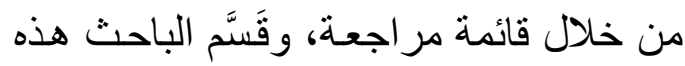
المكتبـات إلى قسمين: الأول للمكتبـات التي أتاحت الخدمة فعليًَا للمستقيدين ووفرت لهرت لهم ورش العمـل و الــدعم الكـافي لاسـتخدامها، وكـان عـدهـا مب مكتبـة انفردت الو لايـات المتحدة بالعدد الأكبر فيها، أمـا في القسم الثاني من الدراسة حصر الباحث 7 r مكتبـة امتلكت الطابعـات الثلاثيـة، ولكنهـا لـم تقدم

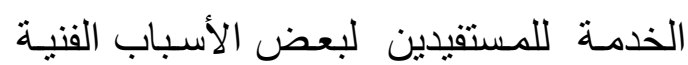


ثامنًا: الإطار النظري لخدمة الطباعة ثلاثية

$$
\text { الأبعاد: الإطاد }
$$

1ـ النشأة الطباعة ثلاثية الأبعاد داخل المكتبات:

قبل بداية الحديث عن توقيت دخول خدمـة

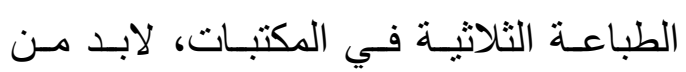

الإشارة إلى تـاريخ أو نشأة الطباعة الثثلاثية

الأبعاد نفسها للتعرف على البعد الزمني بين

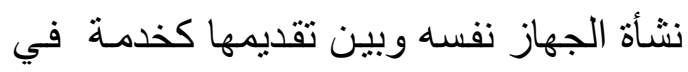

$$
\text { المكتبات. }
$$

وقد اختلف العلمـاء على التوقيت المحدد

لنشأة الطباعـة ثنلاثيـة الأبعاد، فـالبعض حدد البـاء

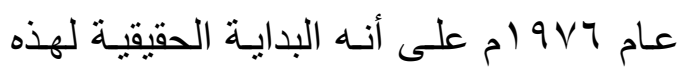

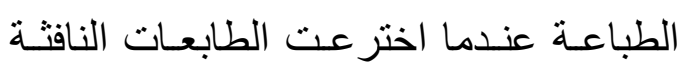
للحبر، و أثبتو ا وجهة نظر هم في ذلك بأنه مع التكيف و التقدم في استخدام الطابعة النافثة للحبر تحولت هذه الطابعة من نفت الحبر للطباعة إلى نفث عدد من المواد، وبالتالي هده صـنعت تلــك الطابعـات الثناثيــة كتطــور

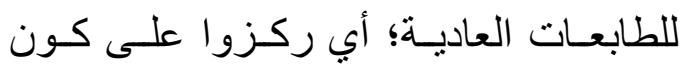
النشأة لبست في التطور في التكنولوجيا بـل

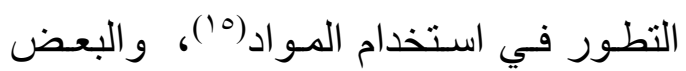
حدد عام ـ91 ام بأنـه عـام الو لادة الحقيقيـة للطباعة ثلاثية الأبعاد، و التي ابتدعها العالم سـكوت اس S.cott كتكنولوجيـا للتصنيع المجسم(1)"، و البعض الآخر أثنـار إلى أن

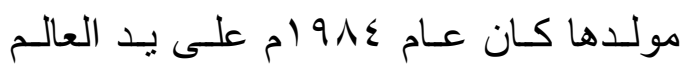
تـشارلز هــول Charles Hull المؤسـس
ومسمايتها المختلفة وطبيعة عملـها وهدف إنشائها وقيمتها، وكيف أنها تمثنل جزءً أساسيًا من طبيعـة عمل المكتبـة وخـاصـة ونة المكتبات الجامعية بعد ذلك عرضت أسمـاء لعدد أربعة أماكن للصنع في أربع مكتبـات لمعناء جامعية بالو لايات المتحدة، وتناولت البـاحثة الموضوع بشكل نظري دون ذكر منهج لار استها أو أدوات جمع بياناتها. ويجدر الإشارة إلى إنها يوجد عدد من من

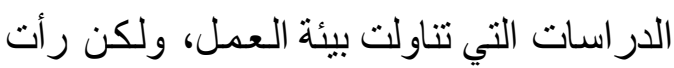
الباحثة عدم عرضها؛ لأنها لم تختلف جميعها في عرضها للجانب النظري الخاص بمكان

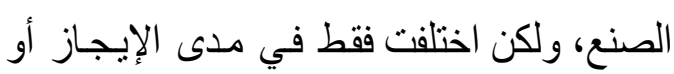
التفيل في شرح أجهزة المكان. و واستفادت الباحثة من الدراسات السابقة في إعدادها للجانب النظري، وفي طريقة عرض ومعالجة الموضوع وبالحصر المذكور في متنها للمكتبات، وفي إعدادها لقائمـة المر اجعـة، واختلفت معهم في أن هذه الدراسـات كانت در اسات لمكتبة واحدة أو أكثر، وليس حصرًا شاملاً لخدمة تقدم في عدد ساب آ مكتبـة، كما تتميز الدراسة الحالية عن غير ها بقيامها بتحليل نصوص ومحتوى السياسات في تلك المكتبات للخروج بأفضل المبادئ التي تنـاولتها تلك المكتبـات، وذلك لوضـع أسس لسباسـة تحكم الخدمة في المكتبات العربية. 
أيدي الجمهور ، وانتقلت للبيع في الأسواق تحـت اسـم الطابعـات الثخـصية، وبالتالي توزيع واسع النطاق.

وفي عام ه . . r م انطلقت مبادرة على يد العـالم أدريـان بويـر Adrian Bowyer جامعـة بـاث University of Bath باسـ مبـادرة العتـاد المفتوح لبنـاء طباعـة ثلاثيـة الأبعاد تحت اسم RepRap ، و هي مبادرة لصنع طابعـة قـادرة على طباعـة مكوناتها لتصنيع طابعات جديدة بسعر أقل من السوق؛ حتي يتمكن الجميع من استخدام الطابعات التثلاثية و الاستفادة من مميز اتها.

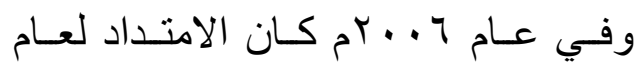
r99 ام في صـناعة جهاز يستخدم الليزر

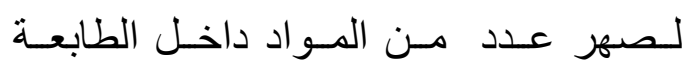
لـصناعة (Selective Laser Sintering) المنتجات بخليط لأكثر من مـادة في التصنيع كاللدائن و البوليمر ات وخلاف ذللك من المو اد التي سيتشكل منها المجسم.

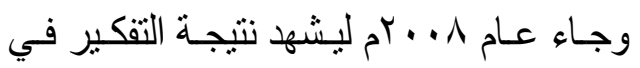

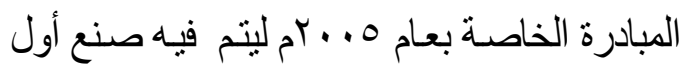

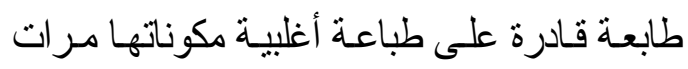
عديدة لصناعة عدد من الطابعات ثلاثية الأبعاد، وتوليد و استتساخ نفسها لمـرات فز ادت الأجهزة

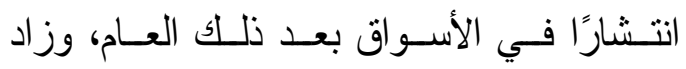

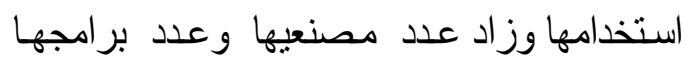
وتطبيقاتها في جميع المجالات العلمية، ومنذ ذلك ونك
المششارك للأنظمـة ثناثيـة الأبعـاد واختراع المجسمات، من خـلال طباعة نمـاذج ثناثيـة الأبعاد يتم إنشاؤها من ملفات وبيانـات رقميـة مية على الحاسب، وفي الحقيقة أيَا كان موعد

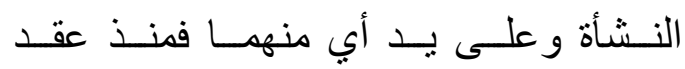
الثمانينيـات وقبله بقليل وحتى الأن، و هنـاك تطور على طول الطريق في هذه الطابعات، و هنالك كثير من التو اريخ الفارقة شكلت معالم رئيسية في تطـور الطباعـة ثلاثيـة الأبعـاد لتصل إلينا بهذا الشكل الذي بين أيدينا وبهذه

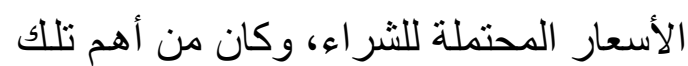
التواريخ الأعو ام التالية: شـهد عـام ب999 ام تطورًا في الطباعـة الطهة نتيجة استخدام جهاز التصوير النحتي المجسم كأحـــــــ (stereolithographic apparatus) الأنظمة ثلاثية الأبعاد الذي يمكن من خلال

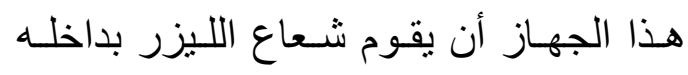

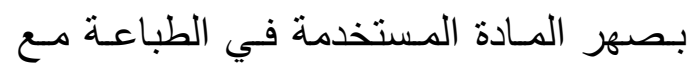
السوائل، و المـواد اللزجـة، و الألـوان لـصنع أجز اء ثلاثية طبقة بعد طبقة، وبهذا أصبحت ولهوان الطابعات تخرج لنا منتجات معقدة التشكيل بمنتهي السهولة وفي وقت قصبر، ولكن

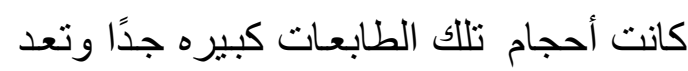
عائقًا للمستخدمين، ولذلك كانت تستخدم في البحث العلمي و الصناعة فقط. انتقلت الطباعة ثلاثية الأبعاد عام ب . . r م

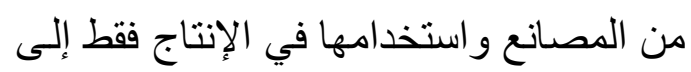


تحول أمرًا شفهيًا غير ملموس إلى كائن

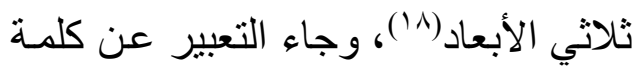

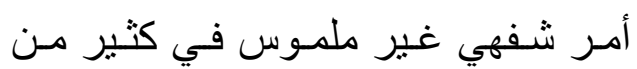
التعريفات بألفاظ عديدة، فـالبعض عرفير فئريا

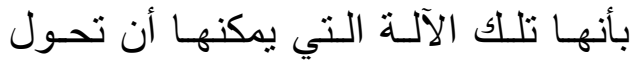

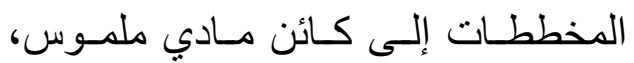
و البعض الآخر عرفها بأنها تلك الآلة التي ملي لـوسي

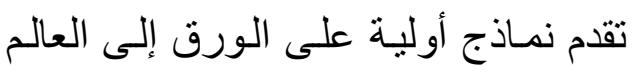

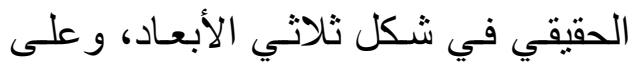

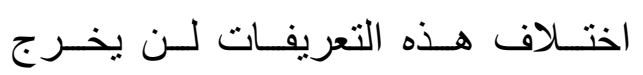

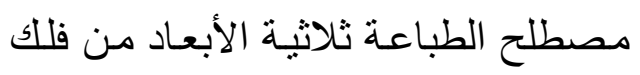

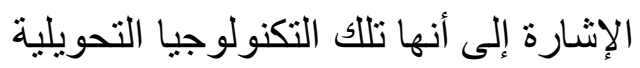

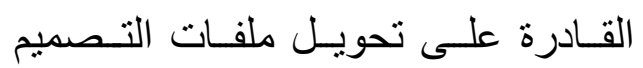

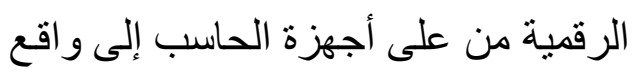
مـادي ملموس ثلاثي الأبعاد، فهي ذلك الك الكي التصنيع الرقمي للنماذج الأولية(19). ب- في حين عرف علماء آخرين الدصطلح

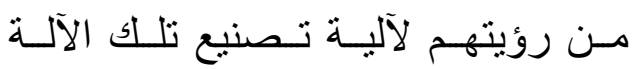

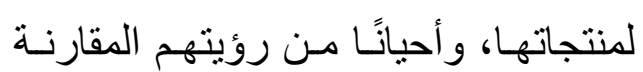
بالآلات الطباعة السابقة، فنجد تعريفاتهم

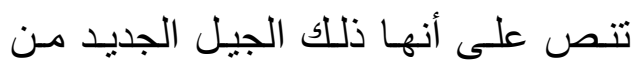

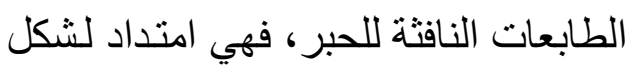

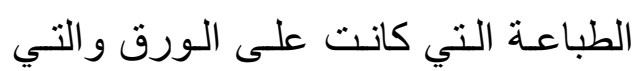
استخدمت فيها الأحبـار ولكن باستخدام

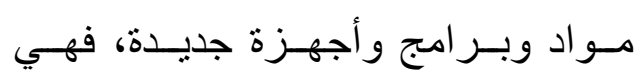
تكنولوجيـا للطباعـة تـذهب بمينًا ويسارًا لطباعة طبقات تلو طبقات بمو اد مختلفة
الوقت و الطابعـات الثلاثيـة يتم تحديثها باستمر ار

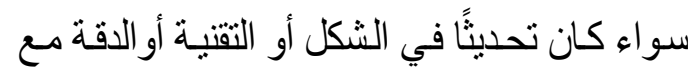
انخفاض دائم في الأسعار ('v).

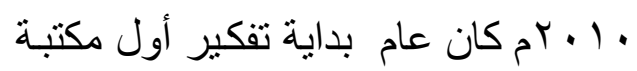

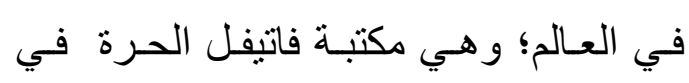

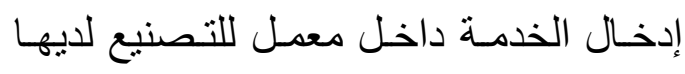

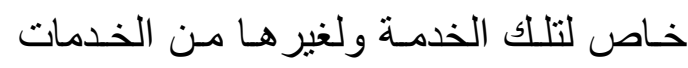

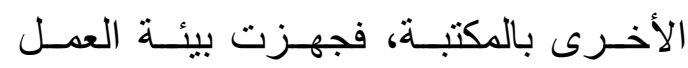
لاسـتقبال الأجهـزة والـبرامج و المــتـفيدين

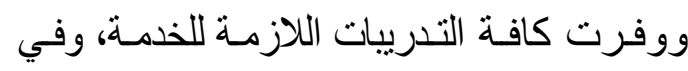
عام 11 + بام كانت الإتاحة الفعلية لخدمة الطباعة

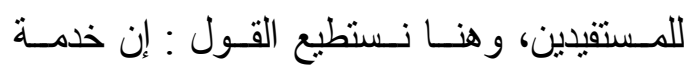

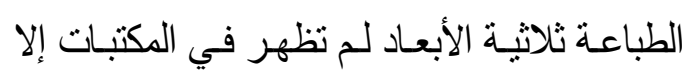

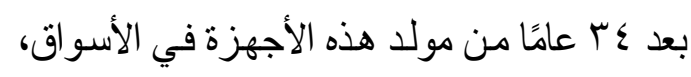

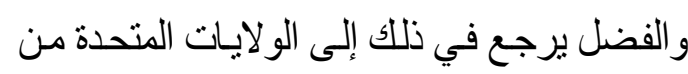
خلال مكتبتها التي أثنعلت الشرارة الأولي لباقي لإني

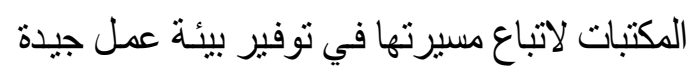

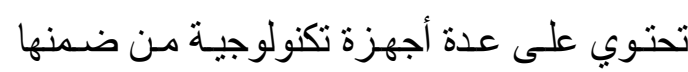

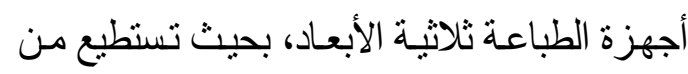

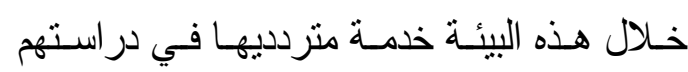
العلمية والبحثية، ومن هنا كانت البداية الحققيـة للخدمة داخل المكتبات. r- الطباعة ثلاثية الأبعاد: التعريف: اختلفت الرؤى التي عرف مـن خلالها

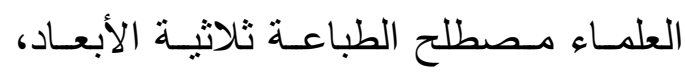
فالبعض أشتار إليها على:

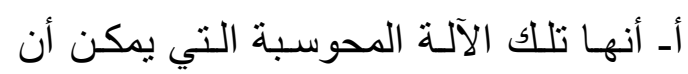


دعت الحاجـة إلى ذلك مـن خـالال طباعـة المكونـات التالفة في دقائق ليستفاد منها في دي تكملة المهام العلمية و الميدانية بفاعلية، ودون أي خسائر في الأرواح أو المعدات، فمثنًا أعلنت وكالة ناسـا عن هذه التكنولوجيـا أنها ستوفر لبعثاتها للفضاء كثيرًا من النفقات التي كانت تتكلفها في نقل كثثر من الأشياء البديلة

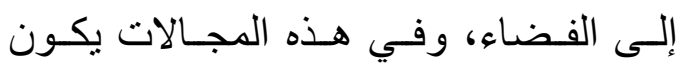
استخدام الطابعات خارج إطار المكتبة(r؟). أمـا في (الكيميـاء، و الفيزيـاء، و الهندسـة،

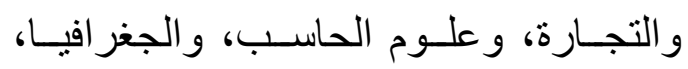
والفنـون الحرفيـة) فيـــتخدمها البــاحثون و الطلاب في دعم بحوثهم، وإجر اء النمـاذج

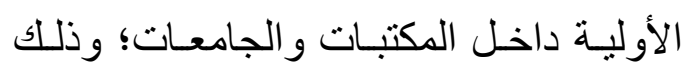
لـدعم بـر اءات الاخـتر اع وفي مسشاريعهم الهندسية، وتصميم المباني التجريبية، وفي

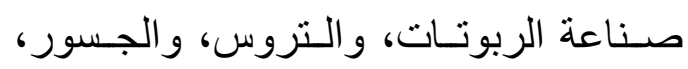
و النمذجــة الهيكليـة للتـضـاريس الجغر افيـة، وصناعة المجو هر ات الشخصية و الصناعية من الذهب و الفضة لتصنيع أشكال جديدة من وهن ولن المجو هر ات وبأسعار أقل، وكذللك تستخدم

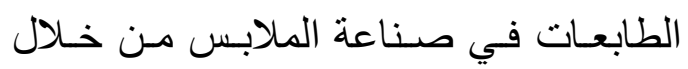
استخدام مادة النـايلون، وبالتالي صناعة عدد من الملابس منثل ملابس البحر، وتستخدم أيضًا في صناعة المنتجـات الغذائية ومن أنشهر تطبيقاتها cornell university مسروع جامعـة كـورن لطباعـة منتجـات غذائيـة تحت مسمى تصنيع في
لبنـاء نمـوذج ملموس بـستخدم في أمور كثيرة وفي مجالات متعددة(·r).

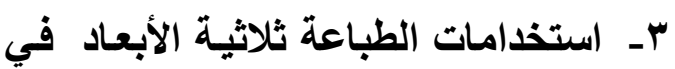
المجالات العلمية:

على الرغم مـن مرور أكثر من ثلاثين

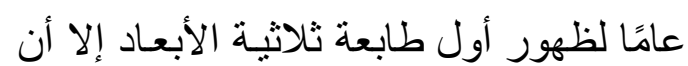
اسـتخدامات الطباعـة ثثلاثيـة الأبعـاد تـزداد

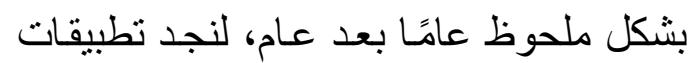

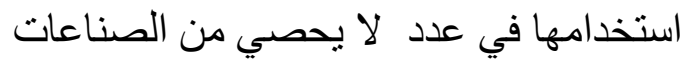
والمجـالات العلميـة، فكمـا غيرت وماز الت

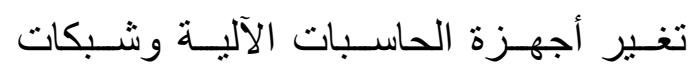

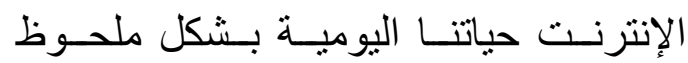
للجميع، فهكا الطابعات ثثلاثيـة الأبعـاد أثرت وسوف تؤثر تأثثرًا عميقًا على صناعة كثير مـن المنتجـات وتـصميمها في عـدد مـن

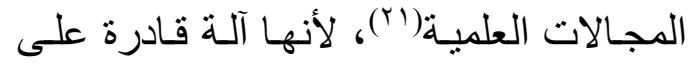

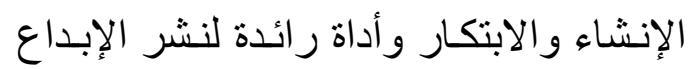
والمعرفـة، فهـي تلهـم الجميـع لاسـتخدامها فالطباعـة ثناثيـة الأبعـاد تكنولوجيـا ثوريـة قادرة على تغيير النموذج الحالي للتصنيع. وتـستخدم الطباعـة ثلاثيـة الأبعـاد في تهي بعض المجـالات لنفس الهـدف فنجـــ مثنلً تـستخدم الطباعـة الثلاثيـة فـي كـل مـن الزيـار ات الاستكشافية للفضاء، و الحروب، والتـدريبات العسكرية، والملاحـة الجويـة، و البحريـة لإعـادة صـنع الأجز اء التالفـة في ولي

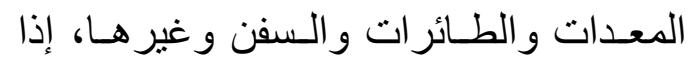


صناعية، أسنان، باستثمار قدره 1 مليون دو لارًا، وتستغرق الطباعة للعضو البشري

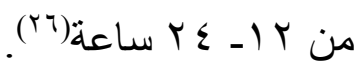
فيمـا سـبق بعـض الاسـتخدامات لهـذه الطابعات في المجالات العلمية المختلفة التي لإني تـستفيد مـن الطباعـة ثلاثيـة الأبعـاد؛ ولأن

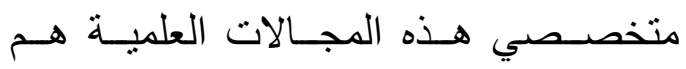

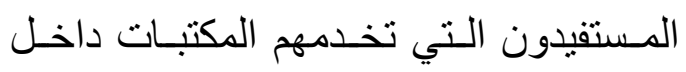

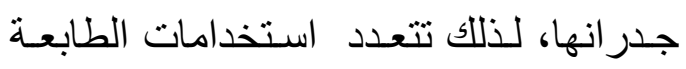

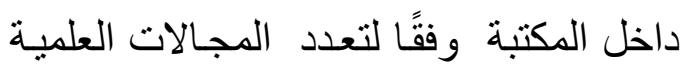

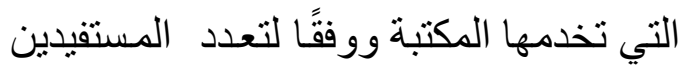
من المكتبة نفسها، فمعظم المشاريع السابقة

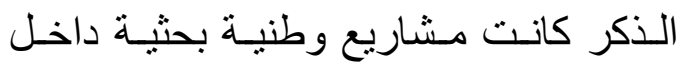
جدران معاهد وجامعات ومختبرات علمية،

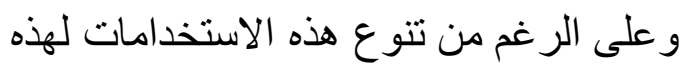

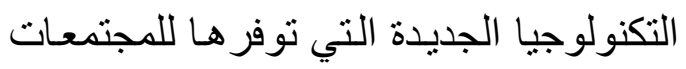

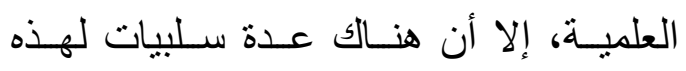
التكنولوجيا ومنها (YY)

أـ لها تأثثير سلبي على صحة الإنسان بسبب

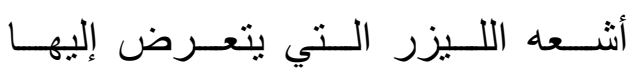
المستخدمون، وبـسبب أضـرار الروائسح المنبعثة من انصهار المواد الخام الخاصـة بالطباعة.

بـ تستخدم بعض المخرجات فيها استخدامًا

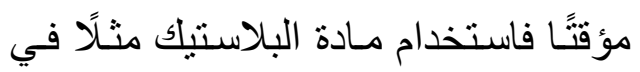
إعـداد المجسمات يجعلها تتـأثر بالبيئة المحيطة من ارتفاع في الحرارة و الضغط لئط

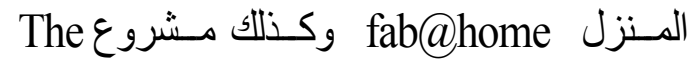
yummiest project MIT prototyping 3dprinters of food الرقية التي تنز اكم في طبقات من الحلوى ليعطي طعيًا لذيذًا قابلاً للأكل (Tr')

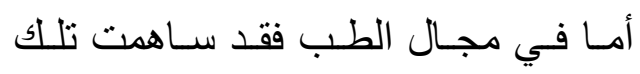

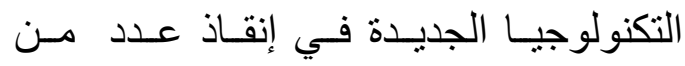

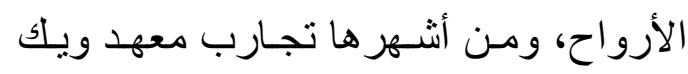

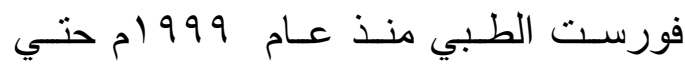
wake forest institute for p ... r regenerative medicine الطابعات ثلاثية الأبعاد لتوليد أجهزة جديدة

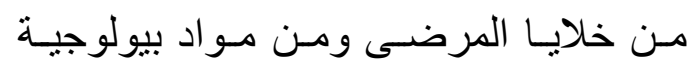

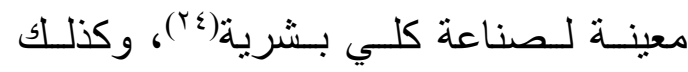

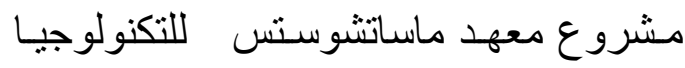
Massachusetts Institute of Technology وكذللك خلق أنسجة يمكن استخدامها لزر اعه كبد الإنسان، وكذلك استخدمت في تصنيع فك اكك

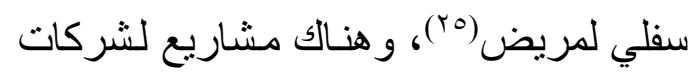

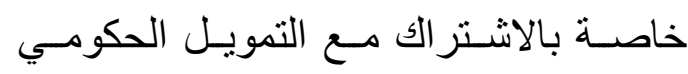

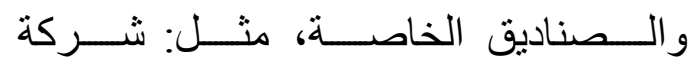

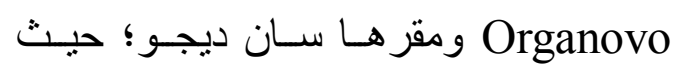
استخدمت هذه التكنولوجيا لتصنيع الأنسجة

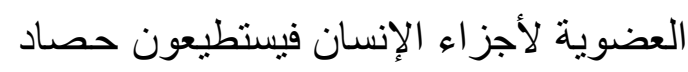

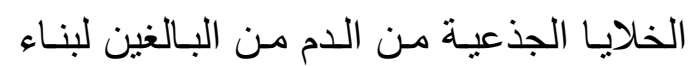

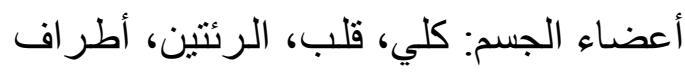


يتصلب عند نقاط محدة بدقة بـاستخدام شعاع ليزر مركز على النقاط المحددة لذلك، فيتم تحويل السائل و الغراء إلى مـادة صلبة شديدة التماسك، وتتحرك الآلة لذلك العمل على ثنلاثة محاور XYZ لبنـاء جميع طبقات النموذج الثلاثي إلى أن يتم خروج الثكل المطلوب كاملًا ودقيقًا في مرة واحدة، فلا نحتاج في نلك الطابعات إلى صنـاعة أجزاء فردية من المنتج لتجميعه، فهي قادرة على بناء نمـاذج ككتله و واحدة

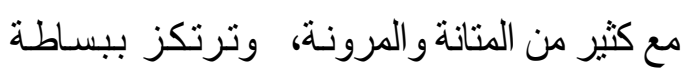

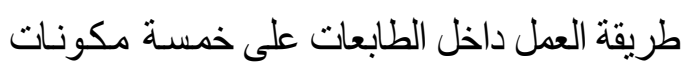
للطابعة، ندرجها في النقاط النالية(ج9). أـ عجــلات الحركــة والــدفع أو المــصعد XYZ Axis وصـود الجهاز لوضـع طبقـات المجسم المطبو عة فوق بعضها، من خـلال ثناثة

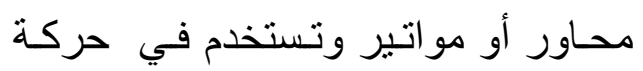
الآلة في صنع طبقاتها. بـ الر أس The Extruder المسؤولة عن

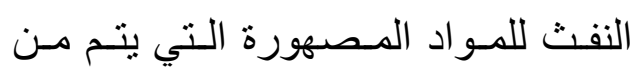
خلالها تشكيل طبقات المجسم نفسها التي يتم إنشاؤ ها طبقة فوق طبقة، ويمكن أن تتكون من مو اد مختلفة و ألو ان مختلفة.

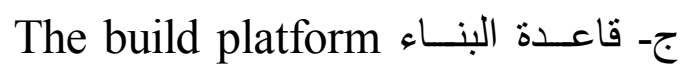
التي يثبت عليها المخرج المجسم، وتسمى لــ و عاء التصنيع و يحتوي على المواد التي تستخدم في إنشاء المنتج ثلاثي الأبعاد.
الجوي فتتهالك وتتغير ألو انها وبالتالي لا يمكن الإعتماد عليها لفتر ات طويلة. ج- تعـد الأسـعار المرتفعـة لهـذه الأجهـزة

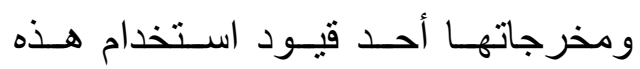
التكنولوجيا.

عـ - كيفية عمل الطابعات ثلاثية الأبعاد: فكرة الطابعات ثلاثية الأبعاد تكمن في فكرة طباعة مخرج مجسم ثناثي الأبعاد، من

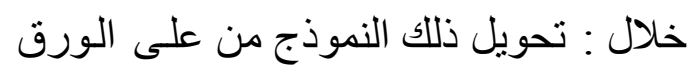
كرسومات عادية إلى نموذج حقيقي ثـلاثي الأبعاد؛ وذللك بو اسطة برمجيات و أجهزة

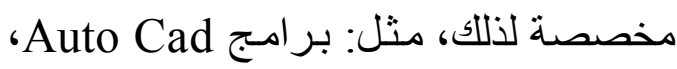
وماسحات ثـلاثيـة الأبعـاد 3d Scanner؛ حيث يتم إرسال تللك الرسومات الجاهزة للطباعة إلى الطابعة لتقوم بعملـها الخاص الخسال بطباعـة مكونـات ذلك النمـوذج من خـلال

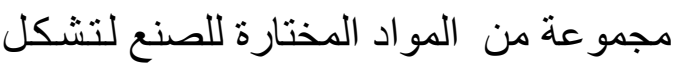
طبقة رقيقة تتلو ها طبقة أخرى، يتم إعدادها من تلك المواد المنثورة في الطابعة_أيا كانت طبيعة تللك المواد ـ لتشكل طبقات منتالية

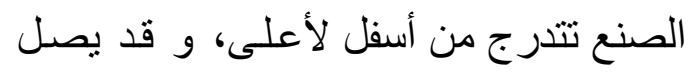
حجم وسمك كل طبقة ميكرون واحد في كل

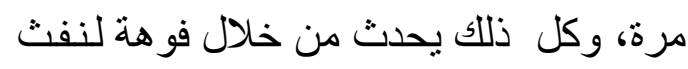
المواد تضع مخرجها على قاعدة مخصصـة ونصة

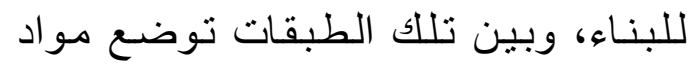
لاصقة، مـثل: الــراء السـاخن أو سـائل

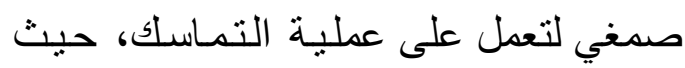


أكثر ، وكلمـا ارتفعت مو اصفات الطابعـة

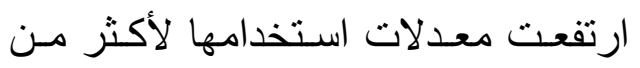
مـادة ومـن تلـك المـواد : البلاسـتيك، المعادن كالذهب و الفضة ، و الألومنيوم،

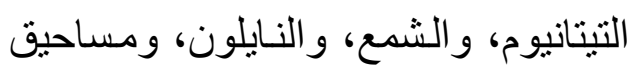

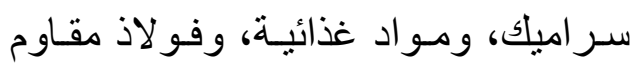

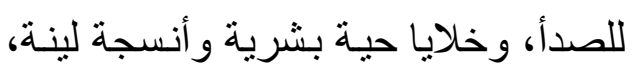
مو اد عضوية، مثل: العظام.

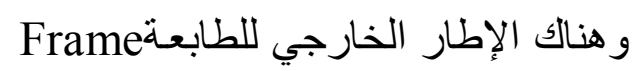
وهو عادة من الخشب أو المعدن، و ليس لله أي علاقة بآلية العمل في الطابعة في تصنيع مخرجاتها، انظر الثكل رقم (1).
د- الإلكترونيـات The Electronics الخاصــة

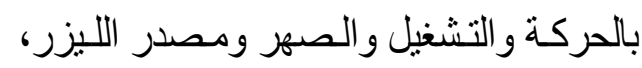

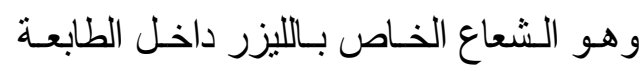

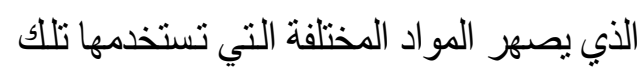

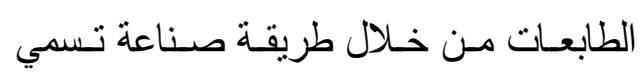
صناعة النمـاذج بالرواسب المنصهرة، بحيث

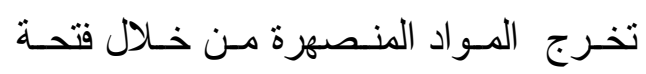
الرأس التي تتفث المو اد المصهورة.

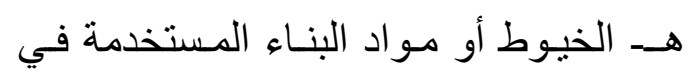
Powder based materials التصنيع التي يتـم مـن خلالهـا تـصنيع الطبقـات Filament

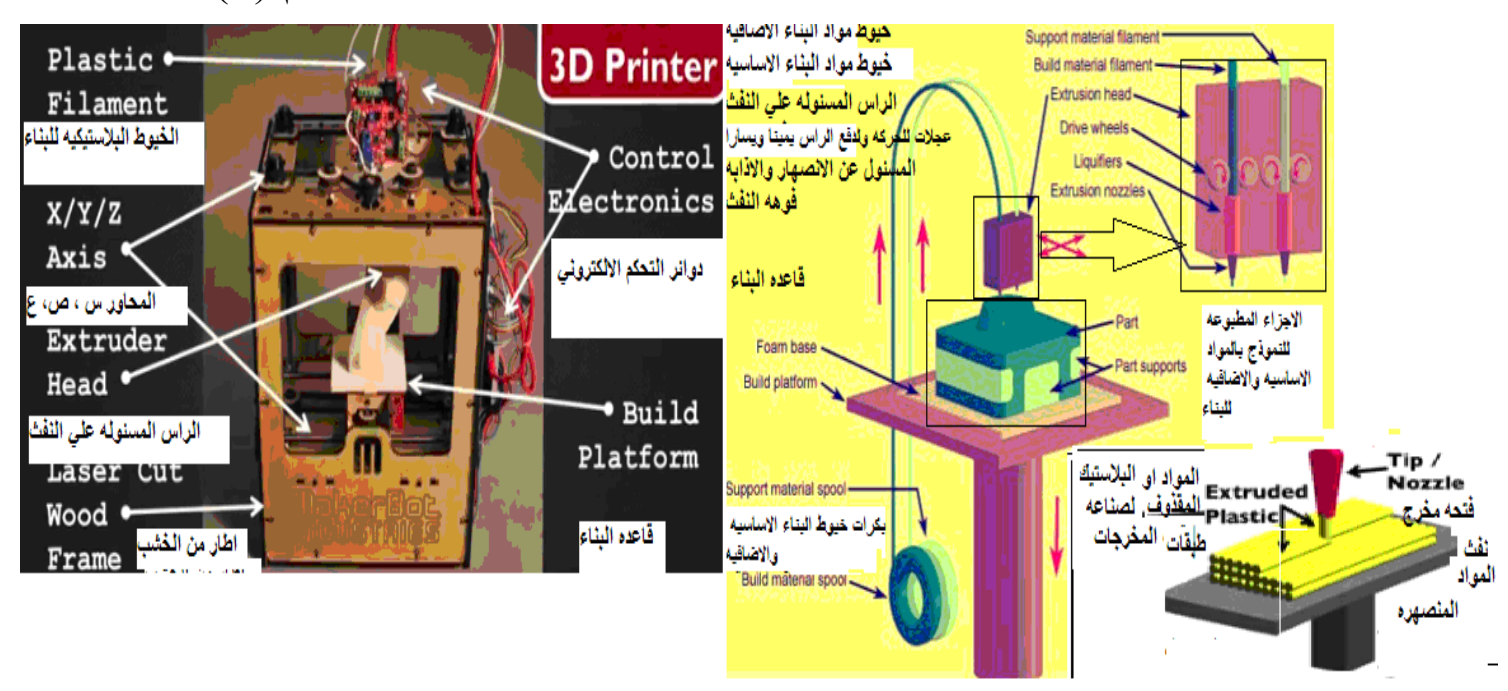

$$
\text { شكل (1) المكونات المسئولة عن العمل داخل الطابعات(·"، ا") }
$$

في إنثاء التصميمات الأولية للمخططات قبل

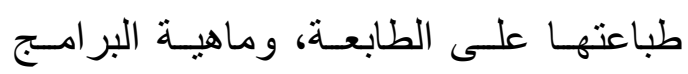
و الأجهزة المستخدمة لذلك؛ لأن هذا النموذج المطبوع في شكل ثناثي الأبعاد يبدأ بمخطط

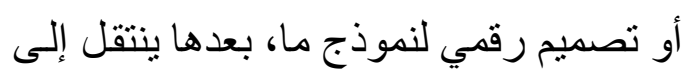

هـ طرق إنشاء التصميمات الثلاثية الأبعاد: ولمـا كانـت السطور السابقة تعبر عـن كيفية وطريقة عمل الطابعات ثنلاثيـة الأبعاد

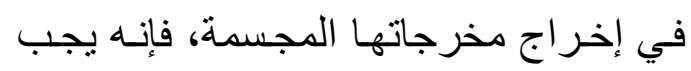
الإشارة إلى الطرق التي يمكن الاستعانة بها 
التصميمات ثلاثية الأبعاد، وليس شرطًا مع بعض هذه المواقع أن تكون مهندسًا فيمكنك كمستخلم

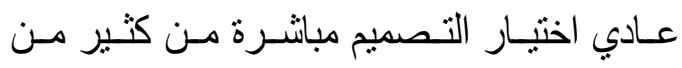
النمـاذج الجـاهزة وإرسـاله لطابعتك ثناثيـة الأبعـاد

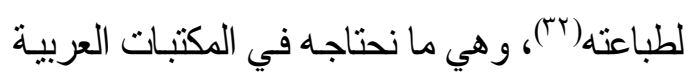

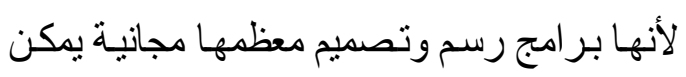

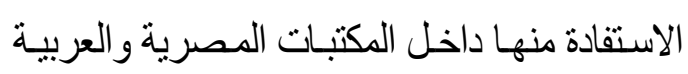
دون الحاجة إلي شر اء فعلي لتلك البرمجيات. الطريقة الثانية:

فتتــم بواسـطة اسـتخدام الماسـحات ثلاثيـة الأبعاد لإنشاء النمـاذج المجسمة من خلال مسح ضوئي لذلك النموذج الفعلي الذي ير اد طباعته؛ حبث تسمح لهذه الماسحات بتحويل هذه النمـاذج إلى ملفات رقمية على الحاسب الآلي يتم حفظها و إرسالها إلى الطابعة لطباعتها في أثكال ماديـة

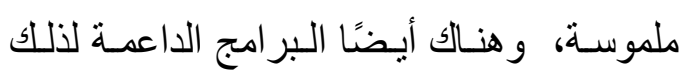
المـسح الـضوئي ليكـون المـستخدم قــادرًا

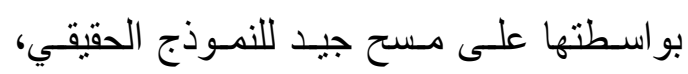
وذلك لتمثيل عـالي الدفة، مثنل: بـرامج Solid

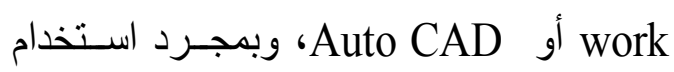

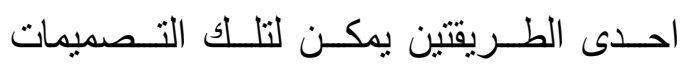

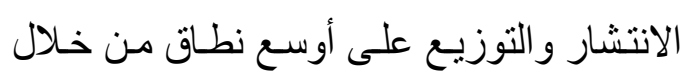

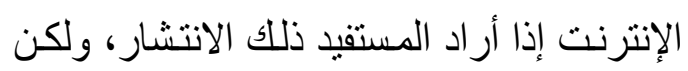
لتظهر هـــه التصميمات كمخرجـات ملموسـة الإنترنة داخل المكتبـة فعلى المكتبـة، الاختبـار مـن بين

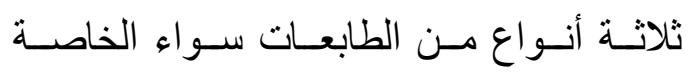
بالإنتاج أو الشخصية أو محلية الصنع (rT).
الطابعة لتنفيذ أمر طباعتهه، و عادة يتم إنشاء ذلك التصميم بطريقتين هما: الطريقة الأولي:

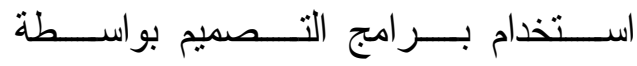

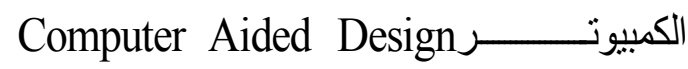
لتصور التصميمات المادية للجسم قبل (CAD) أن يتم إنشاؤه في العـالم الحقيقي؛ حيـث يسمح

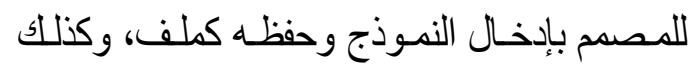
التعـديل فيـه بالإضــافة أو الحـف أو التحريـر أو ولو التلاعب في التصميم كمــا يحلـو لـه حـى يـراه

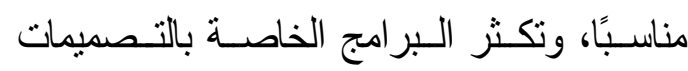

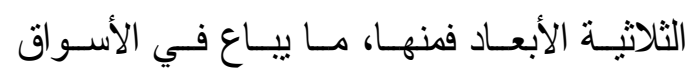

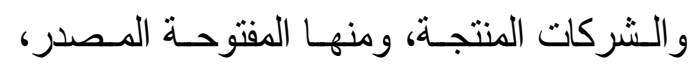
ومنها المحملة على الإنترنت التي تتـاح للجميع ليستقيد منها كل مسن بريد، وبداخل هذه المو اقع لإنـ كثير مـن الـدروس و الفيديو هات المفيدة للمهرة

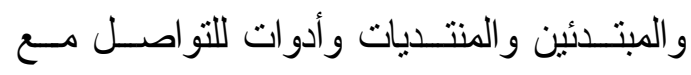
مستخدمي الطباعة ثلاثيـة الأبعاد في العـالم، وهذه وله أمنلـة لبعض مـن تلك النمـاذج التني تتبـح لغيـر

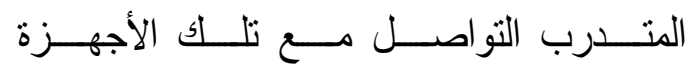

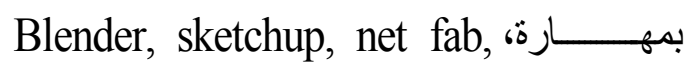
Grabcad, auto desk, tinker cad, Maker Bot's, 3d creation lab, Auto desk 123D, 3d Print uk. Thingiverse, K-Moddl وهذه الأسـماء إمـا لبرامج مفتوحـة

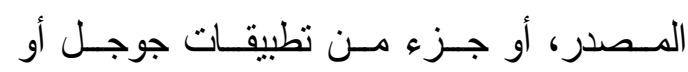
برمجيات وخدمات سحابية غرضـها جميعًا إنشاء 
بحو الي • لَ، • دو لار لكل بوصة مطبو عة ؛ أي مـا

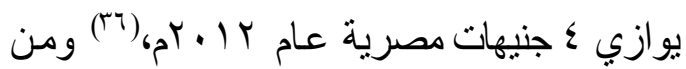
أمثلة هذه الطابعات سواء الخاصة بالإنتاج أو المسماة بطابعات الهواة الثخصية المتواجدة

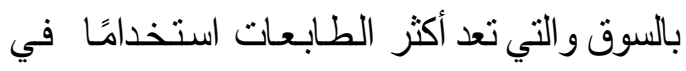

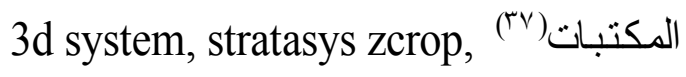
design craft objet makerbot, projet و هذه الطابعات سالفة الذكر هي طابعات مصنعة من مجمو عة من الثركات العالمية تتافس بعضها في الصناعة وفي المواصفات الفنية، مثل: الدقة

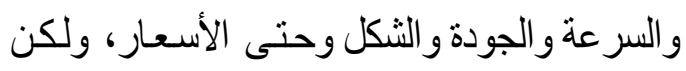
يجب معرفة أنه يمكن الحصول على طابعات

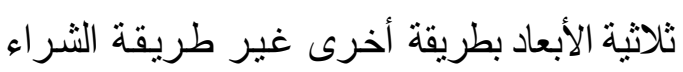
من تلك الثركات وذلك من خلال تصنيعها صناعة محلية. ج - طابعات محلية الصنع: ويمكن للمكتبة إذا أرادت تصنيع طابعات

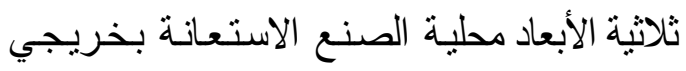
كليات الهنسة و الحاسبات والمعلومات، أو بأماكن الصنع والإبداع الخاصة المنواجدة في البلدان

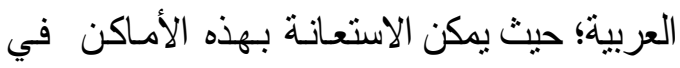
جميع الاستشارات الخاصة بالبناء و التصميم و عقد التدان

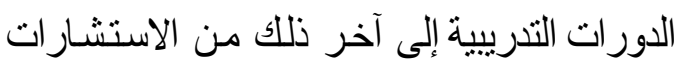
التي قد تحتاجها المكتبات في العالم العربي في بداية عهدها بإذخال تللك الأجهزة، وهذه الأمساكن متوفرة في جميع أنحاء العالم، ومنهـا البلدان العربية، حيث نواجد عام 10 ـ بام ثلاثة عشر ونداه

\section{1- أـ أنواع الطابعات ثلاثية الأبعاد: I ـ طابعات الإنتاج الصناعية:} هي تلك الطابعات التي تهدف لنكون الأساس الوحيد لإخر اج منتج موثوق فيها لطيه عالي

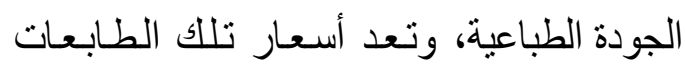
مرتفعة للغاية، وخاصـة إذا كانت تستخدم

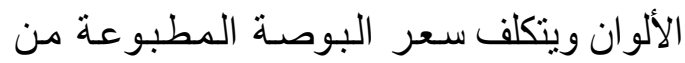

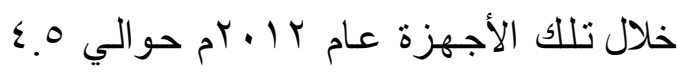

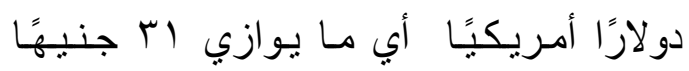

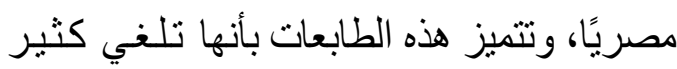

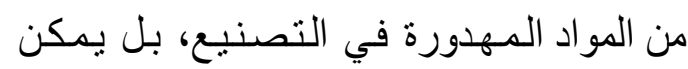

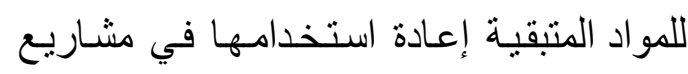
أخرى، على عكس الأسـاليب التقليدية في

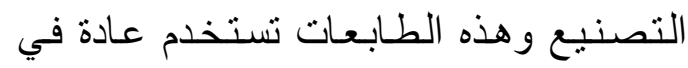

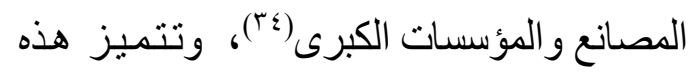

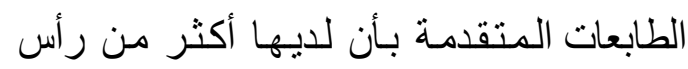
واحد للطباعة، وهي التي تتكون من مخارج

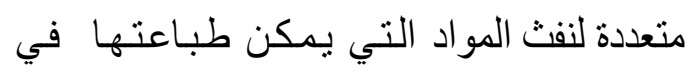
نفس الوقت، وبالتالي يكون لاينا مجسمات بألو ان متعددة ومو اد مختلفة الصنع (ب0). ب ـ الطابعات الثخصية: هي تللك الطابعـات التي صنعت لكاتفة لكافة المستخدمين او للهواة لتشكل حقل التجارب لهم التهم

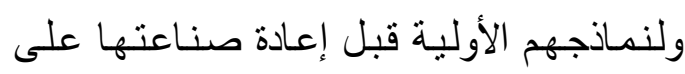

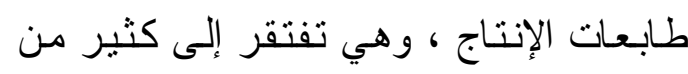

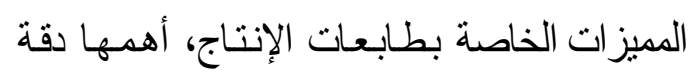

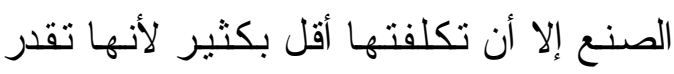


هدفها زيـادة الوعي بأمساكن الصنـع في الثرق

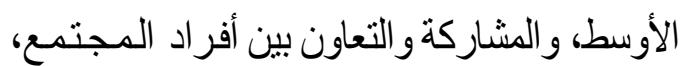
و نشر الوعي بأجهزة ذلك المكان وفكرة الإبداع و والصنع (एq).

ويمكن تصنيع الطابعات محلية الصنع من خلال منتجات متو افرة في الأسواق العربية وفي منتاجر الإلكترونـيـات والحـواسـب الإلكترونية، وبتكاليف أقل من تكاليف السوق العالمي؛ حيث تصل تكلفة إنشاء طباعة ثلاثية

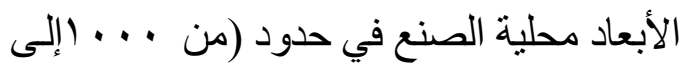

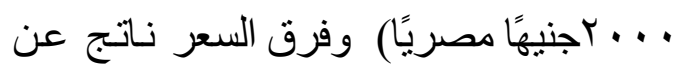
استخدام أدوات في التصنيع داخل الطابعة مستعملة في أجهزة سابقة فتنخفض التكلفة بسبب استخدامها قبل ذلك في أجهزة إلكترونيـة أخرى(·؛)، وطرق وخطوات الصناعة تتو اجد بثكل تقصيلي لهؤلاء الطلبة

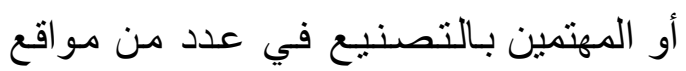
الإنترنت المهتمـة بـالطلابعات ثناثيـة الأبعاد بشكل عام، سواء مواقع حكوميـة، مثل: 3D printer and $3 \mathrm{D}$ printing news in global news organization The Maker Gear Mosaic : تجارية، مثنل 3D Printer مثل: Maintaining and Troubleshooting (₹) Your 3D Printer

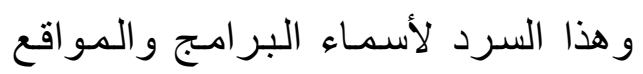
و الطابعات كان ضروريًا ؛ للاطمئنان على لهـ
مكانًا خاصًا للصنع بالبلدان العربية، حازت مصر منهم بثلاثة أماكن منها تقوم بجميع أنشطة أمسكن

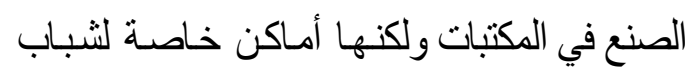
اختاروا هذا النوع من الإبداع أن ينتشر في مصر ويقدمون للمترددين على المكان استخدام جميع الأجهزة المتاحة داخل المكان، بالإضافة إلى تقديم جميع المساعدات التي يحتاجها المترددون سواء من إنشاء وصناعة طابعات ثلاثية جديدة أو تقديم

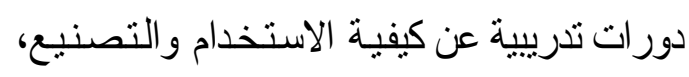

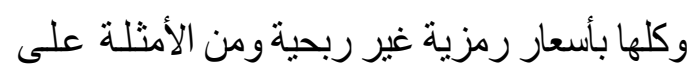

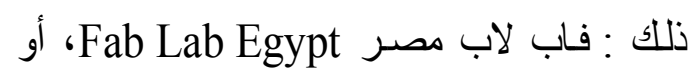

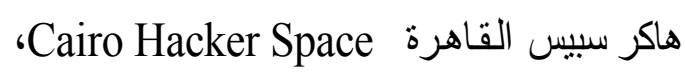
أو هاكر سبيس الإسكندريـة Alexandria Hacker

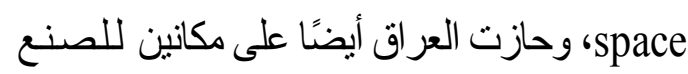
أحدها تحت اسم مساحة الأفكار Fikra Space، و الآخر جيمسي Gemsi ومقرهم بـغاد، وتميزت

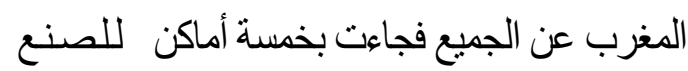
تحت اسم مختبر Sahara Labs (" )، ومعدل المشـاريع الحرة في الدار البيضـاء Enactus Had Kourt و معل حدكورت ESITH Lab HackWara في سوق الأربع، ومسعدل Lab Lab Hacker space Tangier كل من لبنان وسورياو تونس تحت اسم مختبر

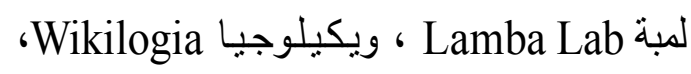

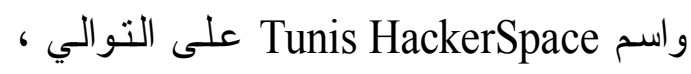
وكلها منظمات غير ربحية نتجت عن مبادرات 
على ذلك قوائم الأسعار التي تعرض على مواقع الإنترنت، والتي توضح أسمـاء جميع الطابعات و البلد المنشأ لها و الشركات المصنعـة، وتكلفة لهنة

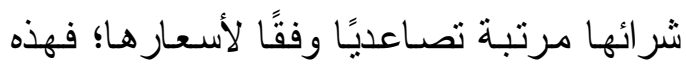
القائمة تتتهي بأسماء لطابعات تصل أسعار هـا إلى نى . . . المليون و النصف جنيهًا مصريًا، ومـا يهمني هنا هو عرض أقل الأسعار فقط والذي يتناسب مع الميزانيات العربية، و الجدول رقم ( ץ) يوضـح أسماء أقل خمسـة أسعـار لطابعات داخل السوق العالمي في هذه القائمة(؟)، والجدول يوضـح أنه يمكن الحصول على طابعة جاهزة من شركاتها

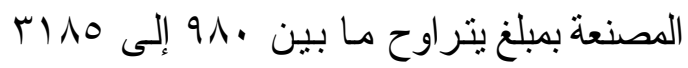

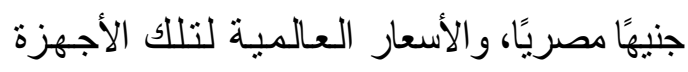
تقترب بشكل كبير من الأسعار الخاصة بـالطابعات المحلية الصنع.
سهولة التفاعل و الوصول إلى طباعـة ثلاثيـة الأبعـاد في المكتبـات العربيـة دون أي

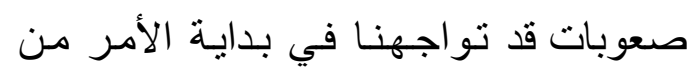
خلال بر امج معروفة ومواقع منتاحة على لإنى الإنترنت وتصنيع محلي جيد بأيدي عربية. V - تكاليف الشراء: V أـ تكلفة شراء الطابعات ثثلاثية الأبعاد: من العرض السـابق نجد أن هناك إمكانية الحصول على هذه الطابعات في المكتبات العربية عن طريق الصناعات المحلية للطابعات، فمن هن

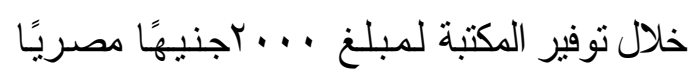

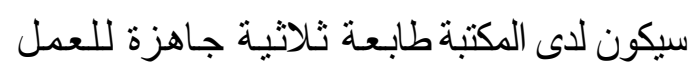

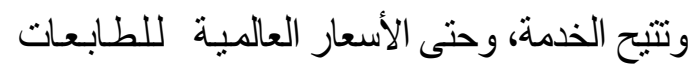

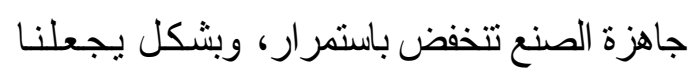
نستطيع إدخال تلك الخدمة داخل جدران مكتباتنا

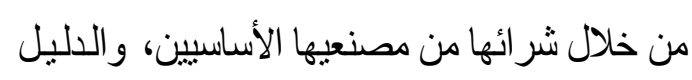

جدول (rّ) يوضح أسماء أقل خمسة أسعار لطابعات داخل السوق العالمي

\begin{tabular}{|c|c|c|c|c|c|}
\hline سعر بالجنيه & سأمريكي بالدولار & اسم الطابعة الثلاثية & اسم الشركة المصنعة & البلا المصنعة & r \\
\hline $9 \wedge$. & $1 \leq \cdot \$$ & $\begin{array}{c}\text { Lix 3D pen } \\
\text { القلم ثلاثي الأبعاد ليكس }\end{array}$ & ليكس Lix & الولايات المتحدة & 1 \\
\hline IVo. & $r \leqslant q \$$ & $\begin{array}{c}\text { New Matter } \\
\text { نيو مانتر }\end{array}$ & $\begin{array}{l}\text { MOD-t 3D printer } \\
\text { الطباعة ثلاثية الأبعاد مود تي }\end{array}$ & الولايات المتحدة & $r$ \\
\hline$r \cdot q r$ & rqq\$ & كابلبوت Cobblebot & $\begin{array}{l}\text { Cobblebot 3D Printer } \\
\text { الطباعة ثلاثية الأبعاد كابلبوت }\end{array}$ & الولايات المتحدة & $r$ \\
\hline Irq4 & $199 \$$ & M3Dام بّدي & $\begin{array}{l}\text { The Micro 3D printer } \\
\text { ميكرو الطباعة ثلاثية الابعاد }\end{array}$ & الولايات المتحدة & $\varepsilon$ \\
\hline$r \leq \varepsilon r$ & $r \leqslant q \$$ & $\begin{array}{l}\text { Printrbot } \\
\text { برينت بوت }\end{array}$ & $\begin{array}{l}\text { New Simple Maker's } \\
\text { نيوسيمبل ماكر كيت Kit }\end{array}$ & الولايات المتحدة & 0 \\
\hline Mi^o & $\{00 \$$ & $\begin{array}{l}\text { Mixshop } \\
\text { ميكس شوب }\end{array}$ & $\begin{array}{l}\text { Mix G1 + Kit } \\
\text { ميكس جي l+كيت }\end{array}$ & كندا & 9 \\
\hline
\end{tabular}


العربية من توفير شـر اء الخـامـات بسهولة وكذللك يمكن لها أن تتحمل عن مستفيديها تكلفة استهلاك الخامات(0). 1ـ - بيئة عمل خدمة الطابعة ثلاثية الأبعاد: كما سبق الذكر في فقرات مضت أن خدمة الطباعة ثلاثية الأبعاد ثتوفر في معظم المكتبات تحت مظلة وبيئة عمل تسمى أماكن الصنع، أو الإبداع، أو الابتكار في المكتبات؛ وهو المكان الذي يوجد في أي مؤسسة ويكـون لـدى المستقيدين منـه الفرصـة لاستكـشاف واسـتخدام جميـع التقنيـات الإبداعية، فهو بيئة تعاونية للتعلم ولتبـادل

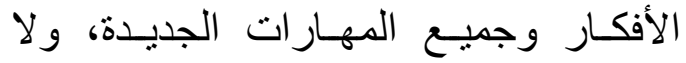
تقتصر فكرة المكان على مجمو عة معينة من المواد أو الأجهزة، و إنمـا جوهر المكان في عقلية الثر اكة المجتمعيـة و التعـاون، وتو افر هذا المكان بالمكتبة يعني أنه يمكن للمستفيد أن يكـون للايـه مسساحة أساسـية للتعلـم و الاكتشاف والإبداع في مكتبته، ولمحو أميته المعلوماتية المستمرة طيلة التطور العلىي، فمن خلال تو افر هذه المساحة في المكتبـة سيتوفر لدى المستفيد البرامج والأجهزة التي أحدثتها ثورة المعلومات، و لا يستطيع معظم المجتمع امتلاكها وذلك لعدد من الأسباب أولها الاقتصادية، وبالتـالي فيمكن للمكتبـة
بـ تكلفة مواد البناء بالطابعات: أما الأسعار الخاصة بـالخيوط أوالمواد الخام للبناء المستخدمة في تشغيل الطـابعـة، فبالنسبة لأكثر المواد استخدامًا في المكتبـات، هي خيوط البلاستيلك سواء الأبيض أو الأسود أو بالألوان فتتر اوح أسعار ها مـا بين 1 ا إلى 1V0 دولارًا للكيلو الواحد، وهي الأسعار العالمية للمواد أي ما يوازي

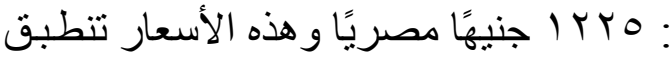
أيضًا على الأخشاب و البوليمر ات والنيلون، أما في السوق المصري فقد يصل تكلفة خيوط البلاستيك بأنو اعها المختلفة إلى . 70 جنيهًا مصريَّا، مثل: PLA Polylactic Acid البلاستيك الحراري القابل للتحلل ABS Acrylonitrile Butadiene وهـو بـلاستيك حراري ضـار Styrene بالبيئة، و PVA Polyvinyl Alcohol وهو بـلاستيك يذوب في المـاء، وتؤكد إحصائيات الاستخدام في المكتبـات الأجنبية أن تكلفة خيوط البلاستيك تتكلف كأقصى حد لها هو ـ ج دولارًا أمريكيًا للشهر الواحد؛ أي

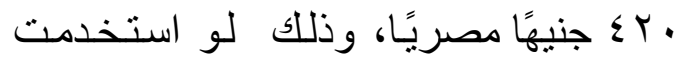
الطابعة طو ال اليوم على مدار الأسبوع دون توقف، وتزيد هذه الأسعـار إذا استخدمت طابعات الإنتاج الكبرى، ومن هذه الأرقام نستطيع القول: إن هناك إمكانية للمكتبات 
Machines وهي آلـة التحكم الرقمي بو اسطة الكمبيوتز وهي من طرق الإنتاج

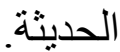
دـ آلة تقطيع الفينيل Vinyl Cutter لقطع الأور اق و البلاستيك و الكرنون.

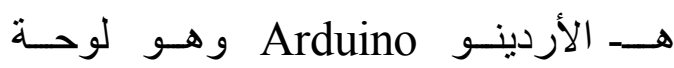
إلكترونية مفتوحة المصدر تتم برمجتها

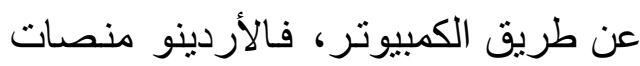
إلكترونية قابلة للنطوير تساعد على عمل دوائر إلكترونيـة ودوائر تحكم، يمكن بر مجتها بصورة سهله باستخدام الأكواد

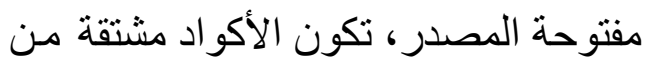

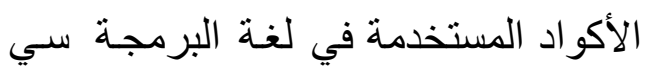
+ و هذه الأكواد يمكن التعديل عليها وبرمجتها بأي لغة برمجة أخرى.

و- جهاز ت و هي ماكينة طباعة لكتب كاملة، وذللك في دقائق معدودة من خـلال قاعدة بيانـات تشمل سبعة ملايين كتابًا تحت الطلب وتحت الحقوق الكاملة للمؤلفين. وباستخدام هذه الأجهزة يكون لدى

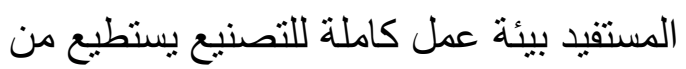
خلالها إنشاء إما نموذج مجسم غير تفاعلي

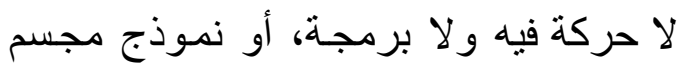

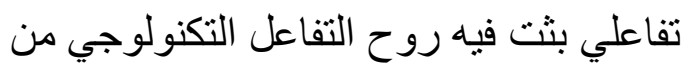

توفير فرصـة الحصول على الأجهزة بالإضـافة إلى توفير الأشخاص المؤهلين المدربين للتعامل مع استخدام هذه التكنولوجيا وبر امجها المختلفة، و تنظيم لذللك دورات تدرييية تعليمية، وورش عمل بشكل مستمر؛ لترويج وتسهيل الاستخدام وللاعايـة لهذا المكان في المجتمع( ؛ ؛ ). ومن ثم أدركت المكتبات أن تخصيص

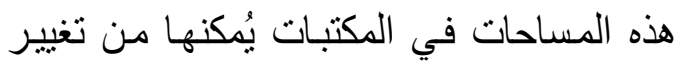

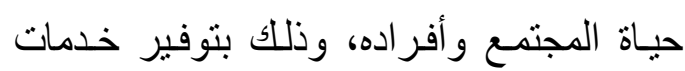

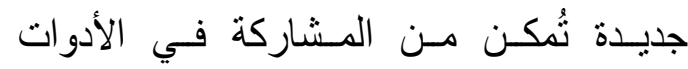

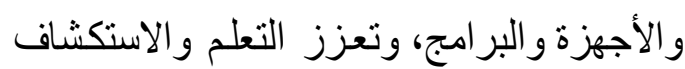
بواسطة اللعب وتحقيق الهوايات وتقديم كافة التجارب العلية و البحثيـة، فتكون للى الدكتبـة المقدرة على إزالة غموض العلوم في الججالات

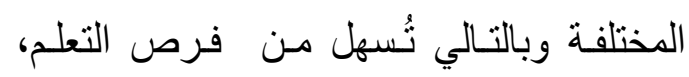
وتوفر المساعدة في إنتاج المعلومات من خلال فئل فرصل

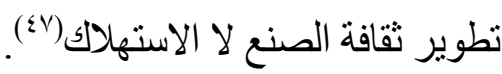
وتحتاج هذه المساحة ـ في إيجاز - إلى لى تو افر ستة أجهزة للتصنيع المجسم يستطيع

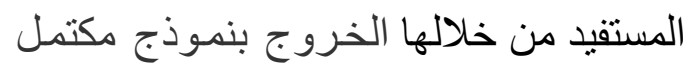

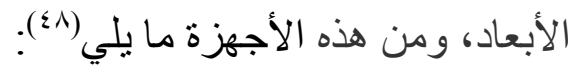
أـ الطابعة ثلاثية الأبعاد 3D Printer. بـ آلة القطع بالليزر Laser Cutte . ج- آلـة تقطيع سـي ان سـي CNC 
التعرف على خصائص تللك الخدمـة ونوعيـة المكتبـات التي قدمتها، و الضو ابط و اللوائح المنظمة لتلك الخدمة علاوة على ما يمكن ان توفره وتحتاجـه مـن ميز انيـات ومـواد خـام

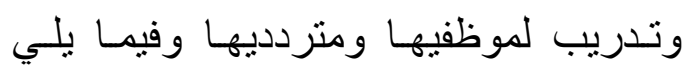
عرض مفصل لتلك الخصائص: ا ـ الدول التي وفرت خدمة الطباعة ثلاثيـة الأبعاد حول العالم:

يظهر من الجدول رقم (ع) أن هنـاك 11 دولة فقط من مجموع دول العـالم وفرت لـن

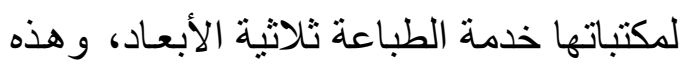
الدول الاحدى عشرة مثلت في قار ات العـالم، عدا قارتي أفريقيا وأمريكا الجنوبيـة التي عجزت دولها عن تقديم مثل هذه الخدمة، كما يظهر الجدول أن دولتين فقط من قارة أمريكا الثمالية هما الولايات المتحدة، وكندا استحوذت انت

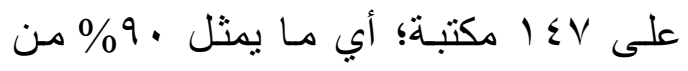

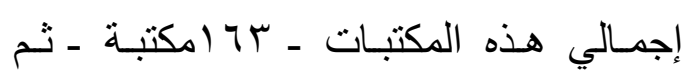

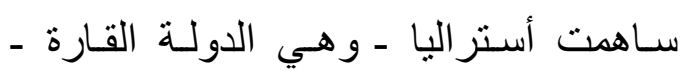

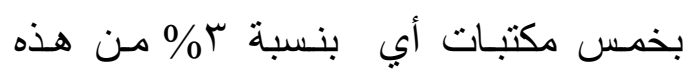

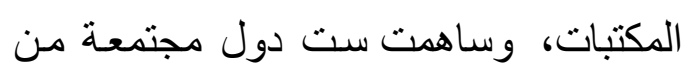

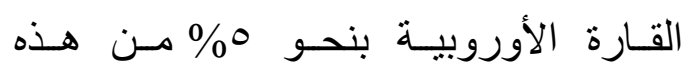

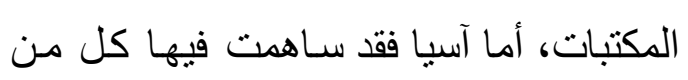
الصين وسنغافورة بمكتبتين أي ما يمثل النسبة الباقية تقريبا ب\%
خلال الأردينو وبر امجهـ مفتوحة المصدر، والتي تبـث روح التفاعل في المجسمات فتتحـرك والمجسمات وتتحـــث وتأندـر بأصو ات مصنعيها. وما يهمني هنا: أنه من خلال توفير هذه

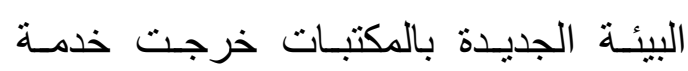
الطباعة ثناثية الأبعاد للجمهور ، سواء أكانت هذه البيئة كاملة الأجهزة ومتعددة الخدمات

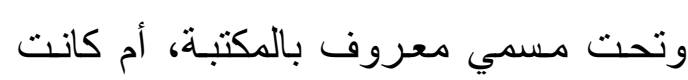

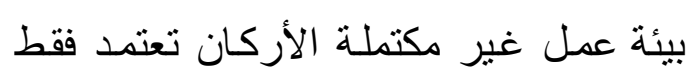
على جهاز واحد تقدم المكتبـة من خلالها خدمة جديدة أو خدمتين لمتردديها دون وضع واحت

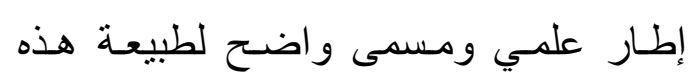
البيئة، فالمهم أن المكتبة استطاعت أن توفر لايها خدمة الطباعة ثناثية الأبعاد من خلال أجهزة الطابعات ثثلاثية الأبعاد. تاسعًا: الدراسة التطبيقية للمكتبـات التي التي تقدم خدمة الطباعة ثلاثيـة الأبعاد حول العالم ومناقشة النتائج: هنـا يـأني دور الشتق الثناني مـن الدراسـة

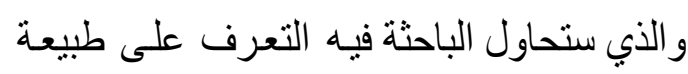
خدمة الطابعات ثناثية الأبعاد في المكتبات التي قدمنها، ويوضـح الجدول رقم (ع) عددًا مـن

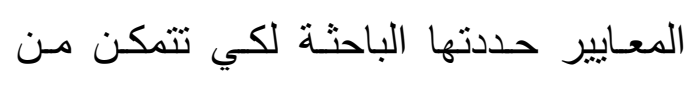


عامـة - بينمـا بلغت مساهمتها مـن المكتبـات

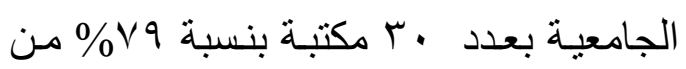

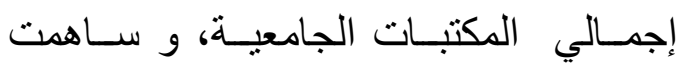
الولابـات المتحدة وحدها بعدد بـ مكتبـات بنسبة \% \% مـن إجمـالي عـد المكتبـات

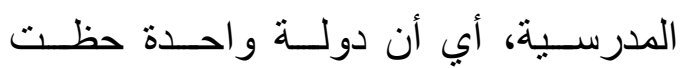
بالنصيب الأوفى في هذا النوع من المكتبات؛ حيث جاءت بثلاث مكتبات مدرسية، تلتها اليونان التي وفرت الخدمـة في مكتبـة واحدة مدرسية للتعليم الثانوي داخل دولتها، وهي

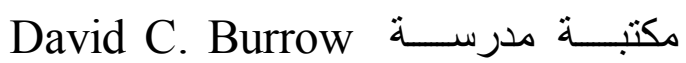
Elementary School Media .Centera أما كندا فقد حصلت فيها المكتبـات العامـة على نسبة \\%، ثم تلتهـا أستر اليا و المملكة المتحدة بفارق مكتبة واحدة بين الدولتين، ثم جـاءت فرنسـا وألمانيـا و الـنرويج وفنلنــدا وسنغافورة في المرتبة الرابعة التي اختارت

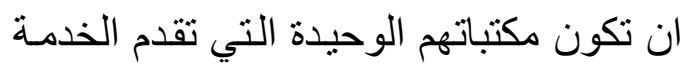

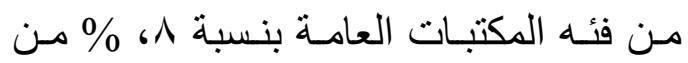
إجمالي المكتبات العامة.

وقبل الحديث عن نسب المكتبات الجامعية فيجب الإشـارة إلـي ان مـن بيـن ^ب مكتبـة

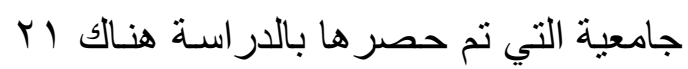
مكتبـة توفر الخدمـة داخل الجامعـة بكاملها بجميع المؤسسات التابعة لها، وليس داخل

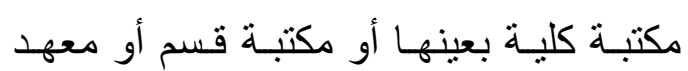

r- أنــواع المكتبـات الـتي وفـرت خدمـة الطباعة ثلاثية الأبعاد حول العالم:

يتضح مـن الجدول رقم (ع) أن هنـاك

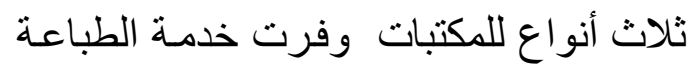
ثنلاثبـة الأبعـاد حول العـالم، كانت المكتبـات العامـة في طليعـة جلب تكنولوجيـا الطباعـة

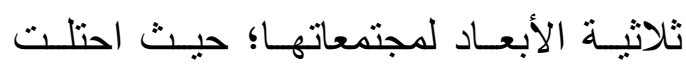
المركز الأول بين نظير اتها؛ حيث حصلت

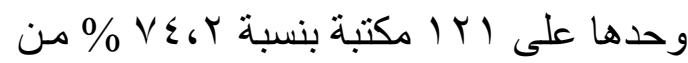
إجمـالي مجمـوع المكتبـات محـل الدراســة، وترجع الباحثة ذلك الي أن منطق هذه الدول ورؤيتها التي أعلنتها بشكل جلي في سياستها ومو اقعها ودعايتها للخدمـة تكمن في توفير تقنيـة جديدة لا يمكن لمعظم أفراد المجتمع ودئ شر اؤها وبالتالي يجب على هلى المكتبات العامـة توفيرهـا للجميـع في شـكل بيئـات تعليميـة

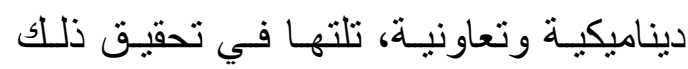
المكتبات الجامعية؛ حيث حصلت على عدد

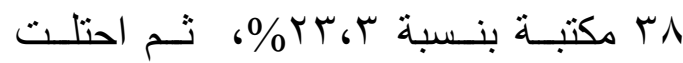

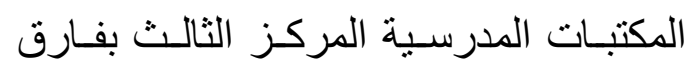
عددي كبير بين المكتبـات العامـة والجامعيـة؛

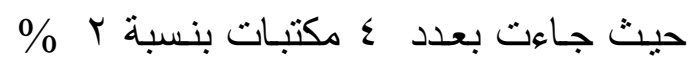
من إجمالي العدد سج آ مكتبة. أما على مستوى الدول نجد أن الولايـات الودن

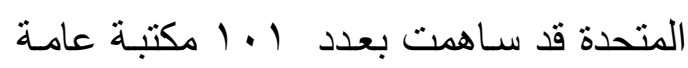
بنسبة س^^\% مـن إجمـالي عـدد المكتبـات

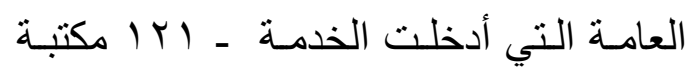


مكتبـة مـن اجمـالي المكتبـات البـالغ عددهـا

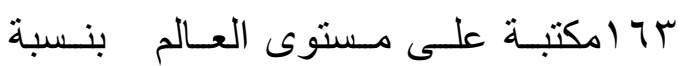
$(\% \vee r$ المصدر الثاني: من خلال الحصول على منح مسن شـركات ومؤسـسات خاصـة ور عـاة للبحـث

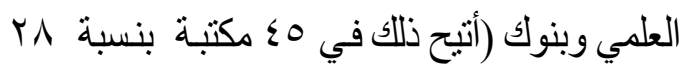
\% من إجمالي المكتبات على مستوى العالم). تميزت الولايـات المتحدة عن غيرها في أني قـدرتها علـى توفـير ميز انيـات لخدمتهــا الجديدة، من خلال تمويل غير تمويـل المكتبـة نفسها ، وذلك عن طريـق منـح المؤسـسات الخاصة ومساهمات الرعاة، وكان ذلك في في ودي اء مكتبة من أصل 0 ؛ مكتبة على مستوى

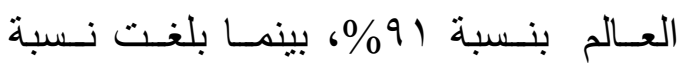
المكتبات الأمريكيـة التي حصلت على منح مـن الممـولين نحو اب\% مـن إجمـالي أعداد مكتباتها على مستوى دولة؛ حيث سهلت تلك لك إنك المؤسسات الحصول على جميع الأجهزة الـتي تـساعد علـى الإبـداع والـصنع فـي المكتبـات، و التي مـن بينهـا الطابعـات ثلاثيـة الأبعاد، و اعتمدت مكتبات الولايـات المتحدة على ستة ممولين فقط قامو ا بتقديم الرعايـة

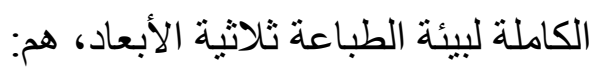
The معهد خدمات المتاحف و المكتبات Institute of Museum and Library Services (IMLS). MacArthur مؤسسة مـاك آرثر
معين داخلها؛ أي إذا تم حساب جميع الكليات

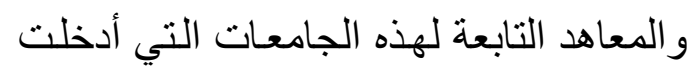

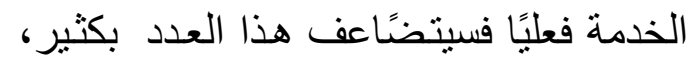
ولكـن نتيجـة تطـابق بيانـات جميـع هـــه

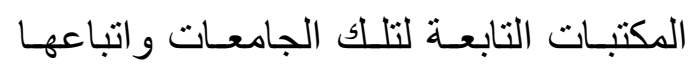
لسياسة واحدة تحكم الخدمـة بنفس العناصر

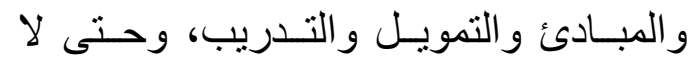

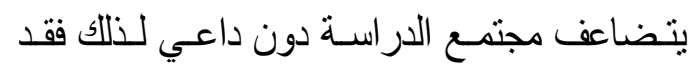
قررت الباحثة اعتبار ها كيان واحد يعبر عنه برقم يحمل بيانـات الجامعة بكاملها، وسـاهدت كندا في ذلك بعدد مكتبـات جامعيـة بنسبة با \%٪، تلتهـا أسـتر اليا، و المملكـة المتحـدة التني جـاءت بمكتبـة واحدة بنسبة ץ\% مـن مجموع المكتبـات الجامعيـة التي وفرت تللك الخدمة علمًا بـان تللك الدولتين من الدول التي قدمت الخدمـة في الجامعة بكاملها؛ أي في أكثر مـن 10 كليـة ومعهد و همـا : جامعـة

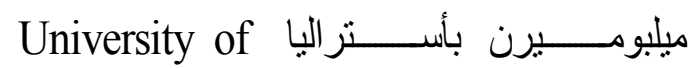

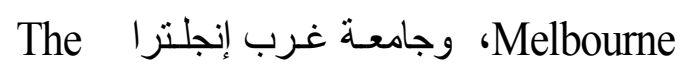
University of the West of England. r- مـصـادر التمويـل الـتي توفـرث داخـل المكتبات محل الدراسة: تم توفير الميز انيات في جميع المكتبات محل الدراسة من خلال مصدرين: المصدر الأول: من خـلال تمويـل المكتبـة نفسها وميز انيتهـا الخاصـة دون الحاجـة إلى ملى الاشتر الك مع رعاة أو ممولين للمساعدة في

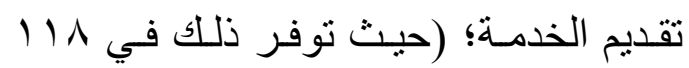


Bank في تمويل مكتبة واحدة فقط،

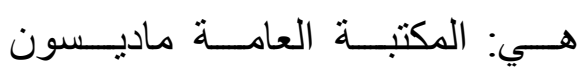
madison public library تذكر المكتبة أيضًا حجم التمويل الذي ولي تلقته على موقعها الإلكتروني.

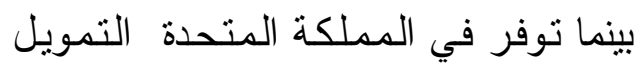

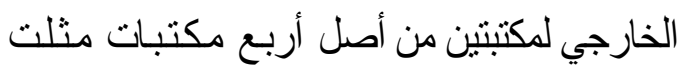

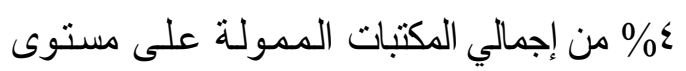

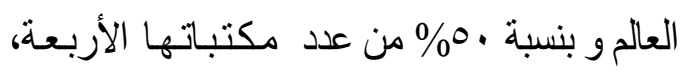

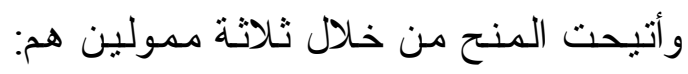

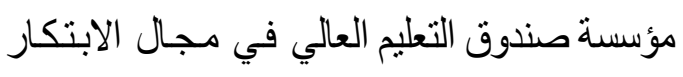
the Higher Education Innovation وصندوق الاستثمار في بحوث Fund (HEIF) Science Research Investment العلوم Fund 3 (SRIF3 تمويل مكتبات جامعة غرب إنجلترا بتمويل قدره

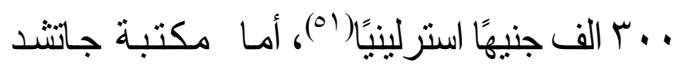
و Gateshead Library وهو مؤسسة كارنيجي The CarnegieTrust الخاص بنوفير الأموال اللازمة للتعليم في

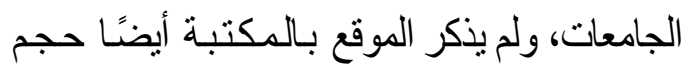
التمويل التي تلقتنه المكتبة. بعدها جاءت كندا في المرتبة الثالثة؛ لأنها

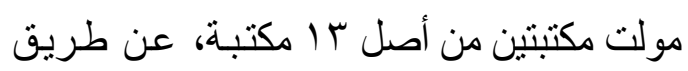

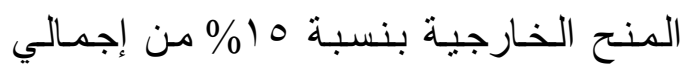

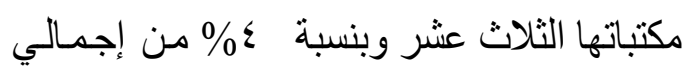
المكتبات الممولة ككل، ومولها ثناثة ممولين، هم : مؤسسة دينسو denso foundation
Foundation المو افقة على إتاحة منح خاصـة لعدد ع ب مكتبـة داخلـل الولايسات المتحـدة

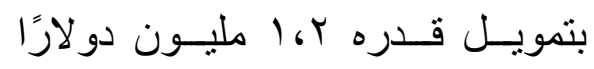
أمريكًا، لإنفاقها في تخطيط وتصنيم

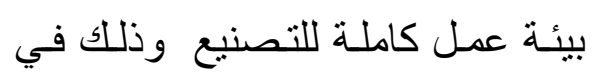

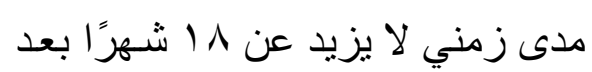
الحصول على التمويل(99؛) ووفـر تحـالف المكتبــات بولايــة نيــو لكويل جيرسـي LibraryLinkNJ وحســــ تمويلًا خارجيًاٍ لعدد 10 مكتبة جامعية

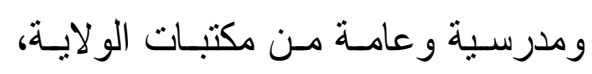

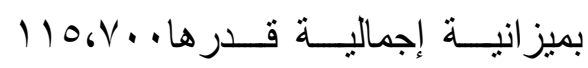

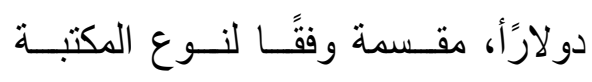

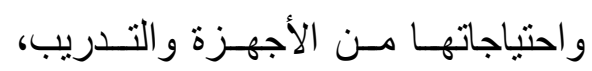

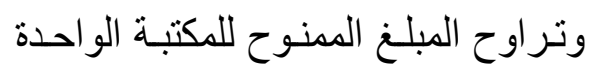

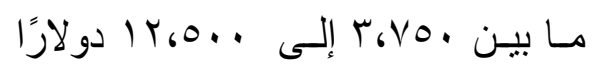
أمريكيًا (0).

ومولـت مؤسـسة العــوم والتكنولوجيــا

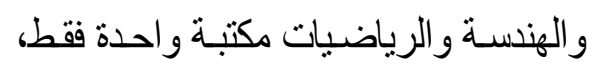
ولم تـكر المكتبـة على موقعهـا قدر هذهـ

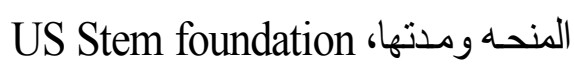
Science, Technology, Engineering and Math و واشـترك الــندوق الوطـني للفنـون The National Endowment Harris for the art 
مكتبة بنسبة YA \% من إجمالي المكتبات محل

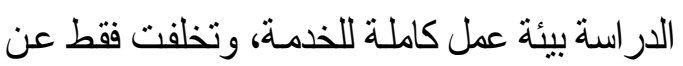

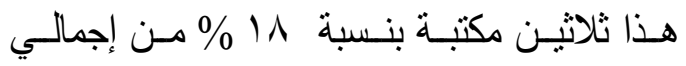
الدكتبات؛ لأنها لم تعلن ذلك على مو اقعها، وهذا دليل واضـح على إدر الك تلك الدكتبات إلى أهيـة وجود بيئة عمل كاملة تعمل خدمة الطباعة ثلاثية

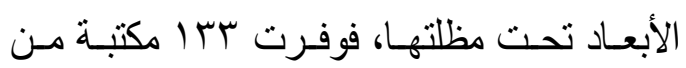
الدكتبـات الككان المناسب للخذمة، وأطلقت عليه

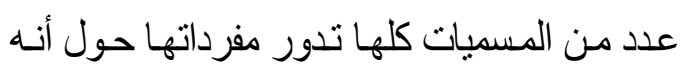
مكان للصنع ولإِبداع وللتخيل وللخلق، ثم وفرت

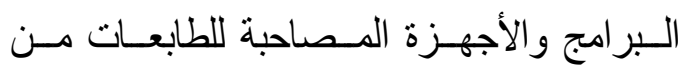

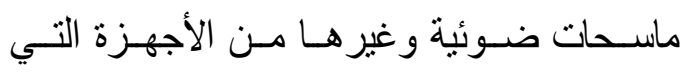
تحتويها تلك البيئة تم طرحهـا في فقرة سـابقة بالدر اسة، وتميزت الولايات النتحدة كعادتها في توفير

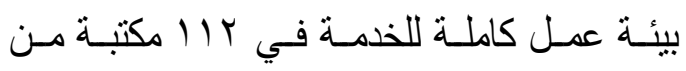
مكتباتها، بنسبة ع^\% من - بآ المكتبة - إعداد الدكتبات التي وفرت بيئة عمل لخدماتها، تلتها كندا

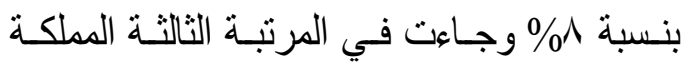

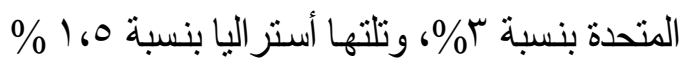
، أمـا المرتبـة الخامسة فقد احتلتها فرنسا وألمانيا واليونان والصين بمكتبة وحيده لكل منها بنسبة

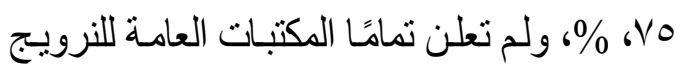
وفلندا وسنغافورة أيـة معلومات عن بيئة عمل فئل

$$
\text { الخدمة على مو اقعها. }
$$

هـ التدريب داخل المكتبات محل الدراسة:

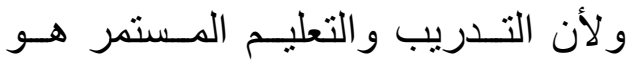

ومؤسسة سترنسيز Stratasys؛ حيث مولت المؤستنان مكتبات جامعة واترلو University of Waterloo

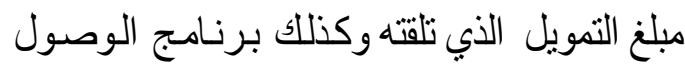
إلى المجتمع community access program The الذي مول المكتبة العامة هانتس كولنستر Colchester-East Hants Public Library وذكرت المكتبة أن البرنامج مول عملية الثراء للأجهزة و البر امج فقط، ولن يقام الرعاية الثناملـة للخدمة بعد الإنثاء، مثل : تكلفة الصيانة وتدريب

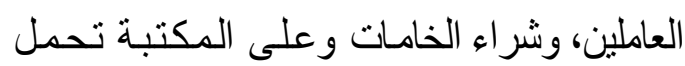
ذللك فيما بعد دون اللجوء للصندوق.

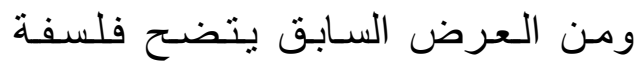
المجتمع الأمريكي والأوروبي في قبول

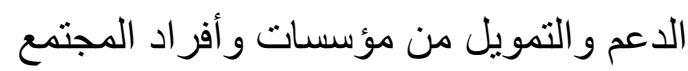
المدني، دون أن تتحمل ميز انية الدولـة أيـة

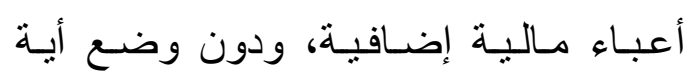

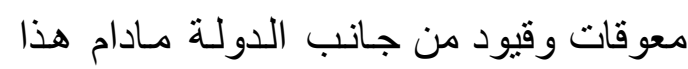

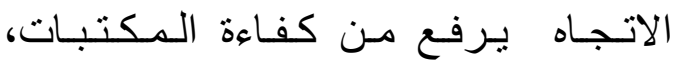
و المؤسسات العلمية، وينـكس على كافة مفردات البحث العلمي. ؛- بيئة العمل التي توفرت لخدمة لخدة الطباعة

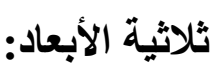
على الرغم مـن أن م؛ مكتبـة فقط هي التي التي

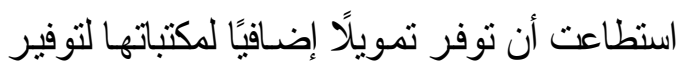

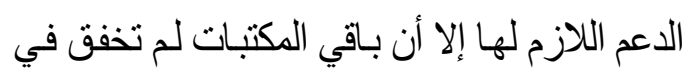
توفير أموال من ميزنياتها تدعم من خلالها بيئة الكية

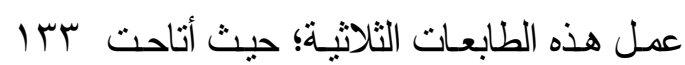


كان يتم الإعلان عنها على مو اقع المكتبات

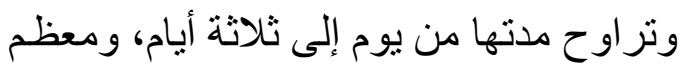

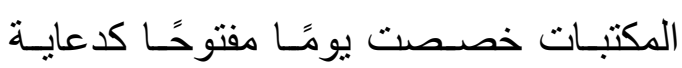
للخدمة وللتسويق لفكرة الصنع أو بيئة العمل

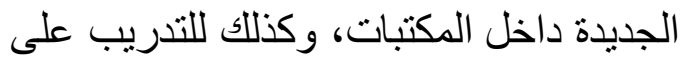

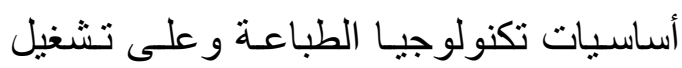
الآلات وطـرق السلامة، وكـذلك استخدام

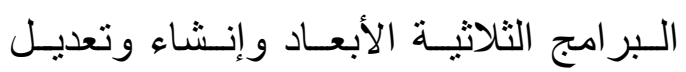
النهـاذج الثلاثيــة وعلى كيفيـة الاثـتـر الك

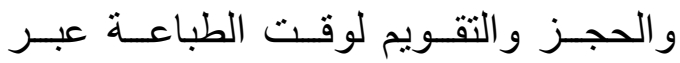
الإنترنت، وأخيرًا التعرف على لوفى بيئة العدل ككل داخل منطقة الصنع بالمكتبة. وتمـيزت مكتبـات الولايــات المتحـــة

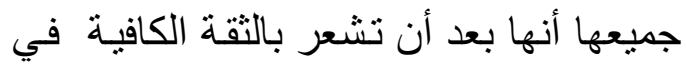
قدرة المستفيد مـن الخدمـة على اسـتخدام

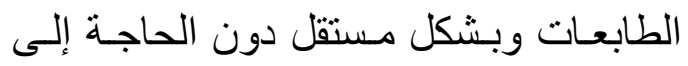
موظفـي الخدمــة يتـم إضــافته إلـى قائهــة المستخدمين المرخص لهم باستخدام الطباعة الثثلاثـــة، ثـم دعـوتهم اللعمـل كمنطو عيـن للمساعدة في تقديم الخدمة للغير، وتميزت كذلك مكتبتان من مكتبات الو لايات المتحدة

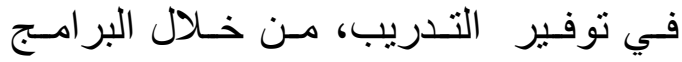
التعليمية التعريفية عبر الإنترنت ؛ للاستفادة منها في التعرف العام على هذه التكنولوجيا و أدو اتها ومو اقعها ومصنعيها، هذا بجانب

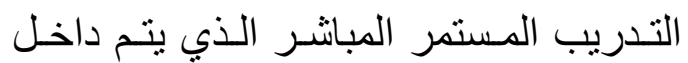

عنصر هام لإدخـال هذه التكنولوجيا داخل الدكتبات ولضمان استمرار عطها بنجاح، فكان هلان

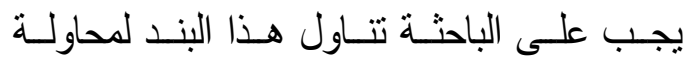
الاستعانة بخبرة هذه المكتبـات عند إدخـال تلك لك لكابل

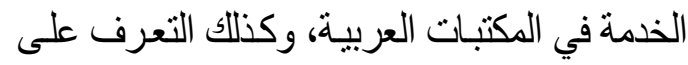
المدى الزمـني المطلوب مـن المكتبـات العربيـة توفيره لتنديب جيد لمستفيليها، ومن الجدول رقم (ع) يتضح أنه قد حظي التدريب بوعي لئي كبير داخل نصف عدد المكتبات محل الدراسة؛ حيث أتاحت دV مكتبة من سا7 المكتبة بنسبة \% \% م تدريب جيد على استخدام الطابعـة ثلاثيــة الأبعـاد وبر امجهـا المختلفـة لموظفيهـا

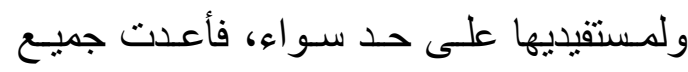

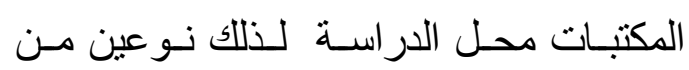

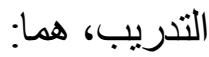
ا- التدريب الخاص بالعاملين:

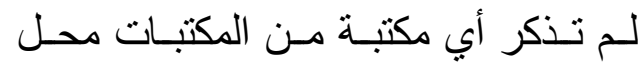
الدراسة من المسؤول الذي قام بتدريب العاملين

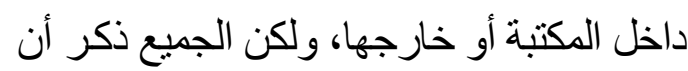

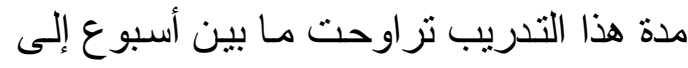

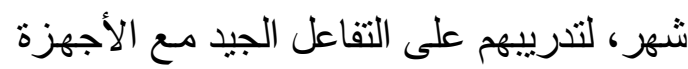
و الرد على أسئلة المستفيدين التي يمكن تلقيها، وذلك قبل إناحة الخدمة للمستفيدين والإعلان

$$
\text { عنها بشهور. }
$$

ب - التدريب الخاص بالمستفيدين: جاء تدريب المستفيدين من خـلال إقامة ورش عمل بشكل دوري داخل المكتبـات، 
لديها، ووقعت في هذا الأمر با مكتبـة من

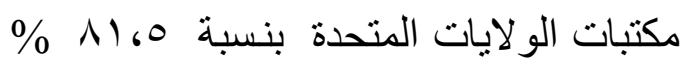
من إجمالي المكتبات التي لم تعلن التدريب، وكذلك فعلت V مكتبـات مس مكتبـات كندا بنسبة 9\% ؛ فزاد عدد المكتبـات التي لـم تعلن التدريب لديها عن تلك التي قامت بـه، وكذللك اختـارت مكتبـات كـل مـن ألمانيـا و النـرويج وفنلنـدا بـأن لا تعلـن عن طريقـة التدريب لديها على مو اقعها. 7ـ تكلقة خدمة الطباعة في المكتبات: أمسا عـن التكلفـة فلقــ ذكرت 00 مكتبـة بنسبة §س\% من إجمـالي عدد المكتبات أن هنـاك مبلغَا مـن المـال سـيتم دفعـه مـن قبـل إنل

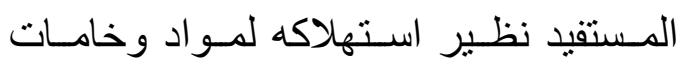
الطباعة، وليس هدفه الربح إطلاقًا لأن نوفير

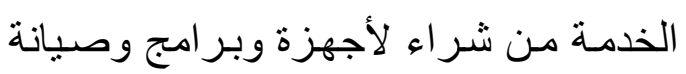
معدات وتدريب مترددين ممولة بالكامل من

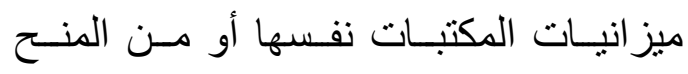
المقدمـه لها، حصلت الو لايـات المتحدة من هذا العدد ـ00 مكتبة ـ على بـ مكتبة بنسبة

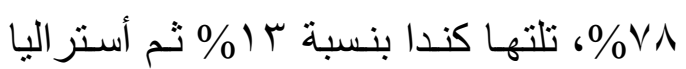
بنسبةV\%) وجاءت في آخر الترتيب فنلندا

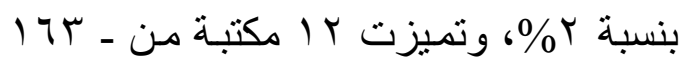

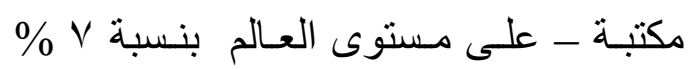

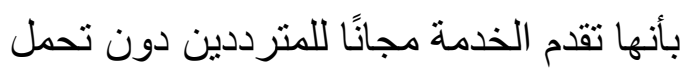
تكلفـة لـسعر اسـتههلاك الخامـات و اختيــار
المكتبـة، ومـن الأمثلـة على ذلك : مكتبـات

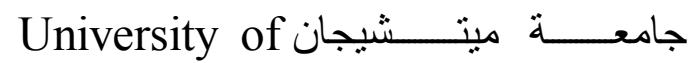
Michigan 3D Lab حيث وفرت موقعًا شاملًا للاعاية عن هذه الخدمة و التكنولوجيـا داخل موقعها، وكذلك تميزت مكتبات جامعة كورنل Cornell university بتوفير جميع النمـاذج ثلاثيـة الأبعـاد الخاصـة بطـلاب قسم الميكانيكا ورندسـة الفضاء، مـن خـلال بنـاء

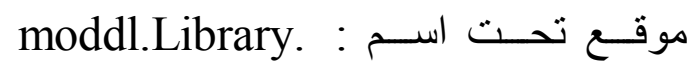
Cornell. edu مستخدمي الإنترنت رؤية تلك النمـاذج بشكل جيد وطباعة واستنساخ نماذجه إذا توفر لديـه

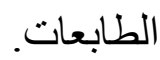

وجاءت في المركز الأول في هذا البند

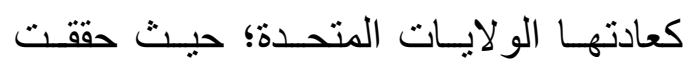
تدريب لعدد م VY مكتبة من NV مكتبة أتاحت التدريب حول العالم بنسبة تصل إلى بم \% \% ، تلتها كندا بنسبة V\%، ثم أستر اليا بنسبة r\%، وبعدها جاءت المملكة المتحدة بنسبة

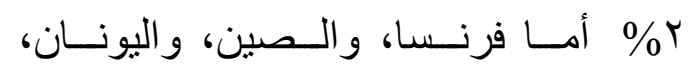

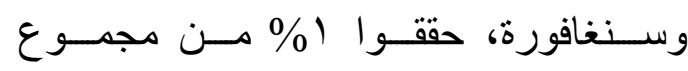
المكتبـات التي أعلنـت نوفير تـدريب على املى مستوى العالم. بينما لم تعلن VT مكتبة بنسبة V إجمـالي المكتبـات على مستوى العـالم على مو اقعهم أية معلومات عن إمكانيات التدريب 
المكتبات التي لم تعلن عن أنواع الطابعات

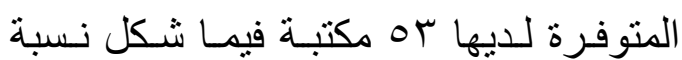
سب\% مـن إجمـالي المكتبـات على مستوى

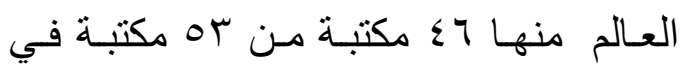

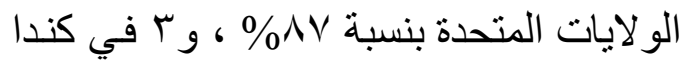

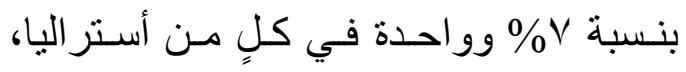
و المملكة المتحدة، وفرنسا، و النرويج بنسبة r \% لكل منهما. أما على مستوى الدول فنجد أن • V مكتبة من مكتبـات الولايـات المتحدة اعتمدت على ملى ملى مله طابعة و احدة فقط في تقديم خدماتها؛ منهـا 7ه مكتبة وفرت نوع و طر از و احد فقط من

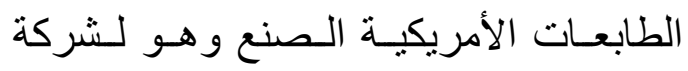
تسمى مـاكربوت، و استخدمت نفس الطـراز أيضضًا مكتبـات ألمانبـا، و اليونـان، و المملكـة المتحدة، وفنلندا، و الصين، وسنغافورة بنسبة

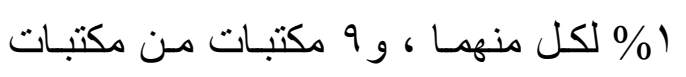

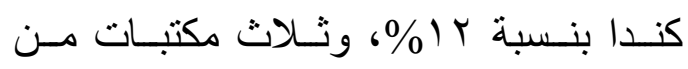
مكتبـات أسـتر اليا بنسبة ب \% \% مـن إجمالـي

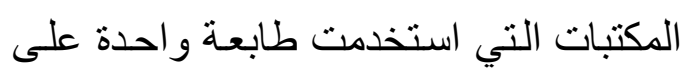
مستوى العالم. 1ـ المـواد المستخدمة في الطباعـة في المكتبات محل الدراسة:

المــواد الـتـي اســتخدمت فـي طباعـة المخرجـات في تلك الطابعـات كانت في في معظـم المكتبــات مـن مــادتي البلاسـتيك الحـراري PLA, ABS، وعلى الرغـم
1. الألوان، ضمت منها الولايـات المتحدة

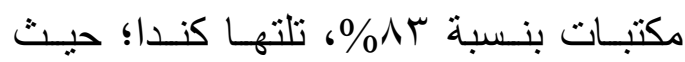
حصلت على مكتبتين بنسبة V ا \% ، ولم تشر جو مكتبـة في مو اقعهـا الإلكترونيـة بنسبة

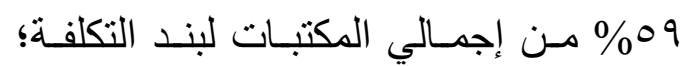
وذللك راجع لعدم تبني ع 9 مكتبة منها سياسـة تقنـن الخدمـة و تنـص على بنـد الإجـراءات المالية للخدمة ؛ كالتكلفة وطرق سداد الرسوم

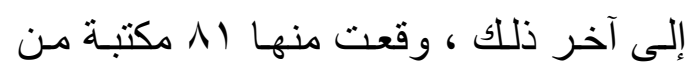

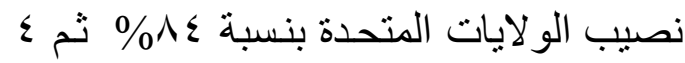
مكتبات في كلٍ من كندا، و المملكة المتحدة بنسبة §\%، ثم جـاءت بـاقي البلدان بنسبة \% مـن إجمـالي إعـداد المكتبـات التي لـم تعلن عن تكلفة لخدماتها. V- أنـواع الطابعـات الـتي اسـتخدمت في المكتبات محل الدراسة:

أمسا من حيث نـوع الطابعات المستخدمة

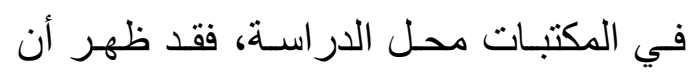
\% 00 مسن المكتبـات علـى مسستوى العالـم وفرت طابعة واحدة فقط، بينمـا بلغت نسبة

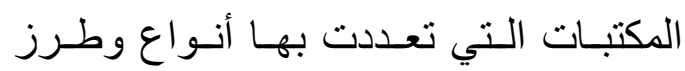

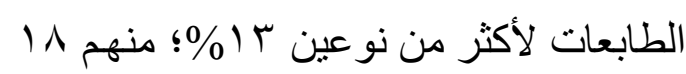
مكتبـة كانـت في الولايـات المتحـدة بنسبة لونسة

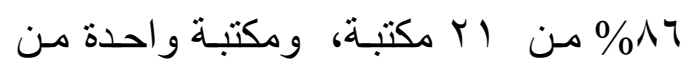
مكتبـات كندا، وأستر اليا، و المملكة المتحدة ولهد

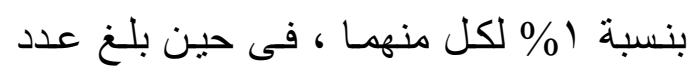


9ـ السياسـات والضضوابط الحاكمـة لخدمـة الطباعة ثلاثية الأبعاد في المكتبات:

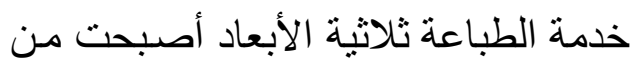

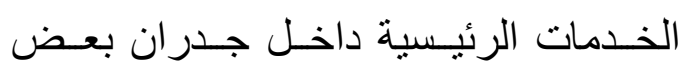
المكتبات، فقد أعلنت بعض المكتبات المتبنية

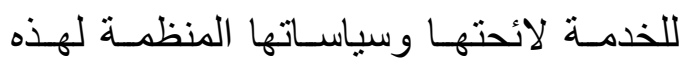

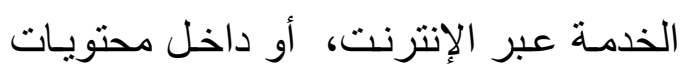

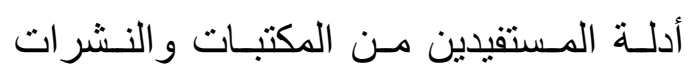

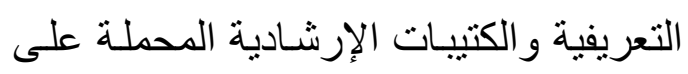

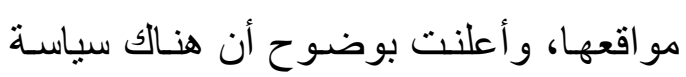

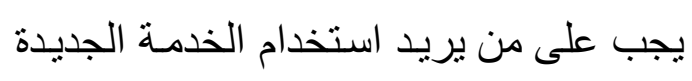

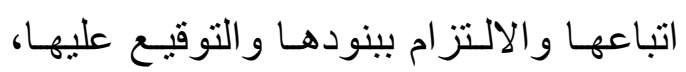
سواء من الثخص نفسه أو من ولي أمره إذا ولئ

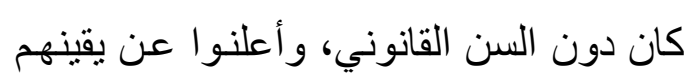
أن إدخـال خـدمات جديـدة بالمكتبـات دون الدون

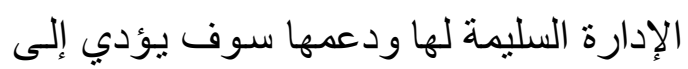

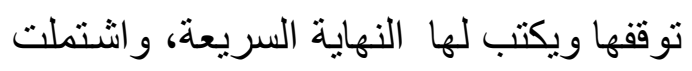
معظم هذه السياسات على عدة بنود، سيتم تناو لها بعد فقرات.

و الجدول السابق يوضـح أن عدد المكتبـات محل الدراسـة التي تبنت سياسـات عمل تحكم الخدمة، وتحدد إجراءاتها 79 مكتبة من إجمالي لتي

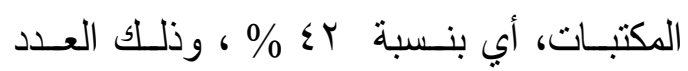
تركز في أربع دول فقط من احدى عشرة دولة قدمت الخدمة، وتميزت مكتبات كندا وأستر اليا

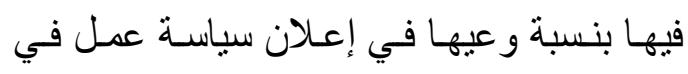
أكثر من نصف مكتباتها، ثم تساوت المملكة
من أن هذه الطابعات يمكن استخدام فيها

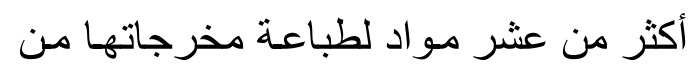

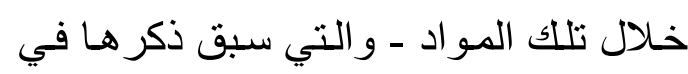

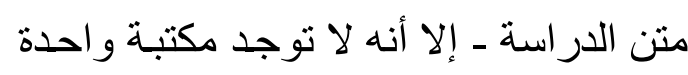

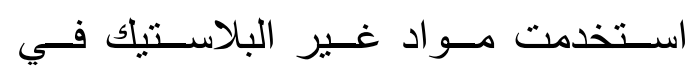
التصنيع؛ حيث استخدم عنصر البلاستيك ميك

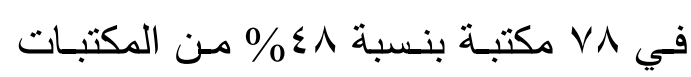

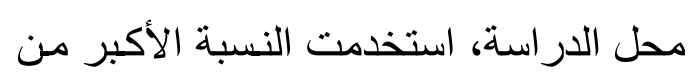
المكتبات عنصر PLA ؛ حيث وصل عدد تلك المكتبات المستخدمة لذلك النوع إلى على اo مكتبة، تلاهـا استخدام عنصر

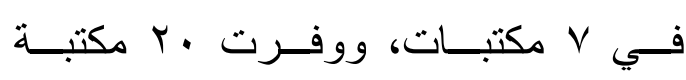

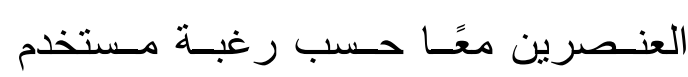

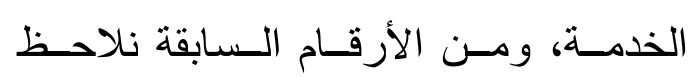

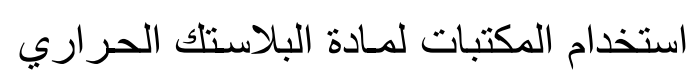
PLA أكثر من مـادة ABS ؛ وذللك لأنها مادة غير ضارة بالصحة وآمنة على البيئة، وهو مـا يجب اتباعه في المكتبات العربية عند إدخال الخدمة.

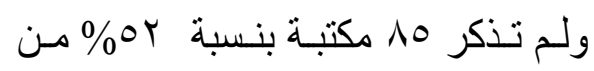

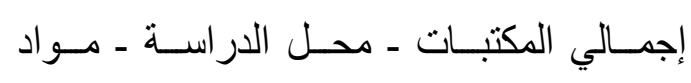

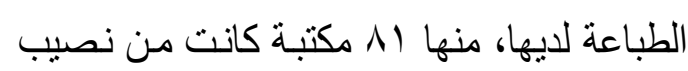

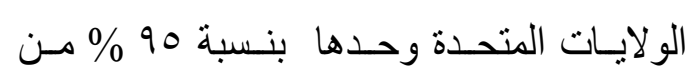
إجمالي العدد الذي لم يحدد على موقعه المادة

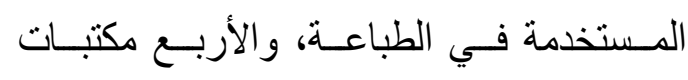

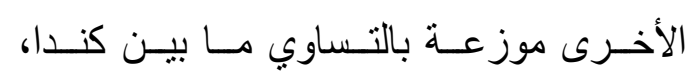

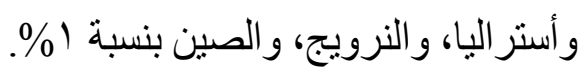


مـا يمسيز سياسـة عن أخرى؛ حنى ينسنى

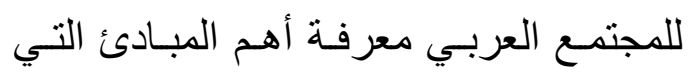

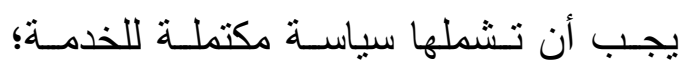
وفيما يلي عرض لمتون تللك السياسات: أ ـ الإطار الخارجي لمحتوى السياسـات

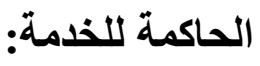

مـن بيـن المكتبـات (79 مكتبـة) التـي استخدمت لخدمتها سياسـة تحكمها وضعت با مكتبة منها سياسة محددة ومكتملة البنود لعناصر سياستها المنظمة للخدمة؛ حيث اتفق

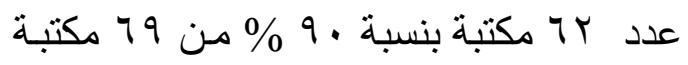
على أن سياسة الخدمة يجب أن تشتمل على هن هن هن

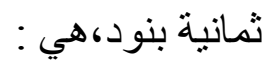
• ت تعريف الخدمة و الغرض منها.

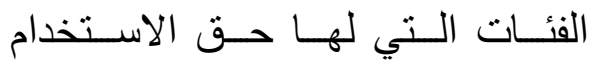
و الطباعة ومسئولية التصميم.

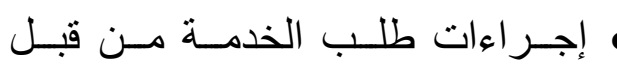
المستفيد. مبــادئ توجيهيـة لـضـمان الحقـوق القانونية و عو امل الأمن و السلامة. مو اصفات الأجهزة و المقاييس النهائية التي يكون عليها المخرج المطبوع. • المو اد الدستخدمة في الطباعة و ألو انها.

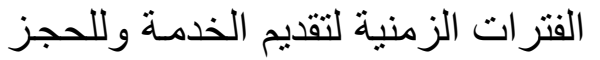

$$
\text { وللحصول على المخرجات. }
$$

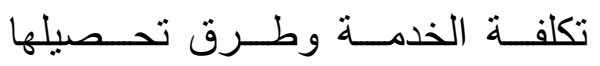

$$
\text { و استردادها. }
$$

المتحدة في عدد مكتباتها التي أعلنت سياسة أو التي لم تعلن بنسبة .0\% من مجموع مكتباتها، وبنسبة r\% من إجمالي المكتبات التي أعلنت

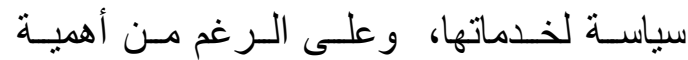
وضع سياسة للذذمة إلا أنه لم تعلن ؟ 9 مكتبة من الدكتبات محل الدراسة لدتردديها أية مبادئ

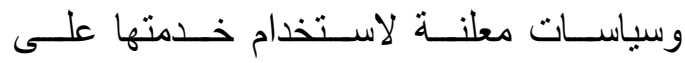

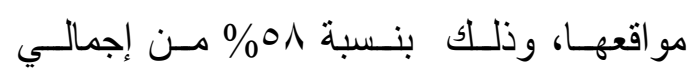

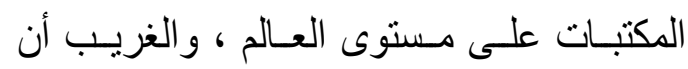
يظهر ذلك في مكتبات الولايات المتحدة، فرغم

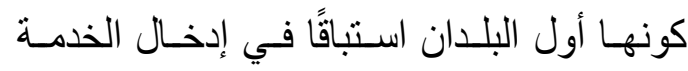

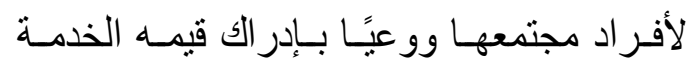

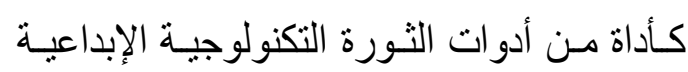

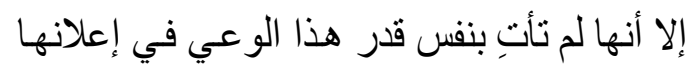

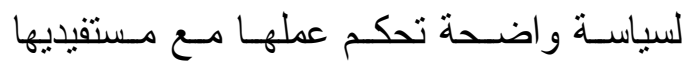

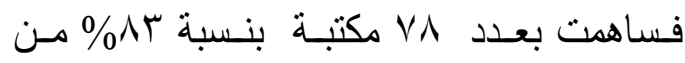

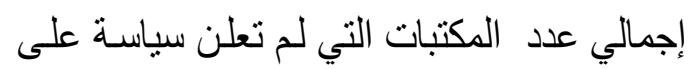

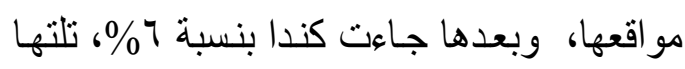
المملكة المتحدة بنسبة ץ\% ، ثم جاءت مكتبات

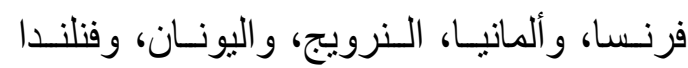

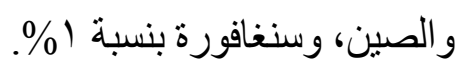

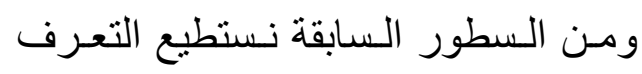

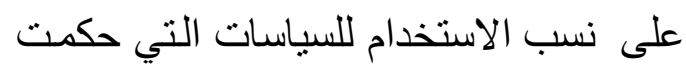
الخدمة ونظمتها في المكتبات محل الدر اسـة، ولكن لمزيد من الاقتراب من الخدمـة كان

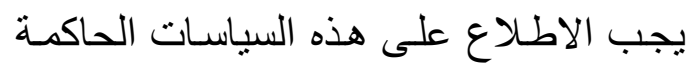
وتحليل بنودها و محتوياتها ، و التعرف على الطى على على على 
الجدول ( • ) الإطار الخارجي للسياسات الحاكمة للذدمة داخل المكتبات محل الدراسة

\begin{tabular}{|c|c|c|c|c|c|c|c|c|c|c|c|c|}
\hline \multicolumn{8}{|c|}{ أنعاء النجبت التب التزبت بلبنو، داخل المبيلة } & \multirow{2}{*}{\multicolumn{2}{|c|}{ تخد المبيست }} & \multirow{3}{*}{ نئي } & \multirow{3}{*}{ 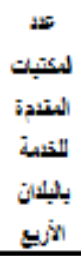 } & \multirow[b]{3}{*}{ أب } \\
\hline \multirow{2}{*}{ لدئلة التئة } & \multirow{2}{*}{ 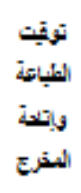 } & \multirow{2}{*}{ 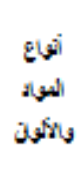 } & \multirow{2}{*}{ 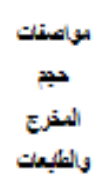 } & \multirow{2}{*}{ 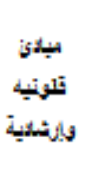 } & \multirow[b]{2}{*}{ القيراءت } & \multirow{2}{*}{ الإنتذاة } & \multirow{2}{*}{ نف } & & & & & \\
\hline & & & & & & & & لثينية & الثتوند & & & \\
\hline 53 & 53 & 53 & 56 & \multicolumn{4}{|c|}{56} & 3 & 53 & \multirow{2}{*}{56} & \multirow{2}{*}{134} & الوزلابت الئدة \\
\hline 95 & 95 & 95 & 100 & \multicolumn{4}{|c|}{100} & 5 & 95 & & & لتببة \\
\hline 7 & 6 & 7 & 7 & \multicolumn{4}{|c|}{7} & 1 & 6 & \multirow{2}{*}{7} & \multirow{2}{*}{13} & IIS \\
\hline 100 & 86 & 100 & 100 & \multicolumn{4}{|c|}{100} & 4 & 86 & & & لتببة \\
\hline 4 & 3 & 4 & 3 & \multicolumn{4}{|c|}{4} & 1 & 3 & \multirow{2}{*}{4} & \multirow{2}{*}{5} & أستراب \\
\hline 100 & 75 & 100 & 75 & \multicolumn{4}{|c|}{100} & 25 & 75 & & & لتعبة \\
\hline 0 & 2 & 2 & 2 & \multicolumn{4}{|c|}{2} & 2 & 0 & \multirow{2}{*}{2} & \multirow{2}{*}{4} & الملكة المتدة: \\
\hline 0 & 100 & 100 & 100 & \multicolumn{4}{|c|}{100} & 100 & 0 & & & لتببة \\
\hline 64 & 64 & 66 & 68 & \multicolumn{4}{|c|}{69} & 7 & 62 & \multirow{2}{*}{69} & \multirow{2}{*}{156} & 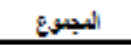 \\
\hline 93 & 93 & 96 & 98 & \multicolumn{4}{|c|}{100} & 10 & 90 & & & لتببة \\
\hline
\end{tabular}

تقع في المرتبة الأولي بنسبة تطبيقها لمعظم

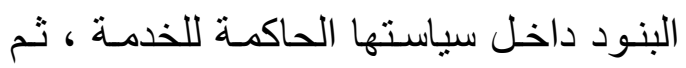

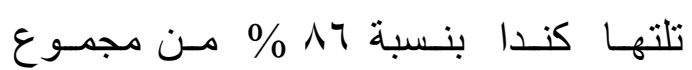

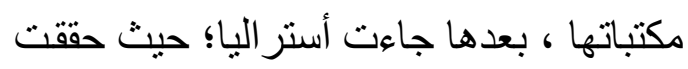
ثناث مكتبات من أصل أربع مكتبات بنسبة \% Vo

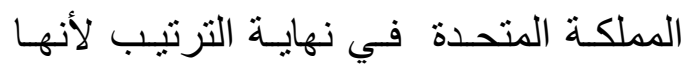
أغفلت بند التكلفة في سياسة خدماتها وبالتالي لـم تحقق أي مكتبـة فيهـا اكتمـال للبنـود في في ولي سياستها للخدمة. أمـا عـن أهـم البنـود داخـل السياسـات

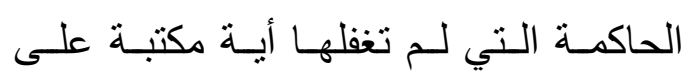

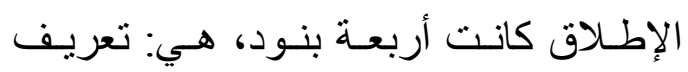

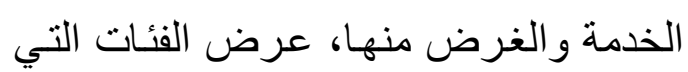
لهـم حـق الاسـتخدام و الطباعـة، و إجـر اءات

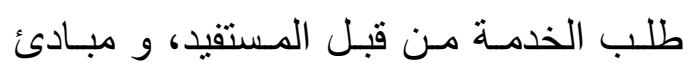

ويدل تكرار هذه المبادئ في با7 مكتبـة من المكتبات التي وضعت سياسة على أهمية وجود هذه المبـادئ والبنـود في أي مكتبـة

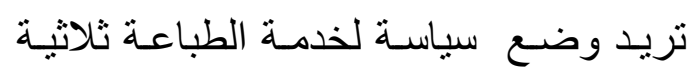

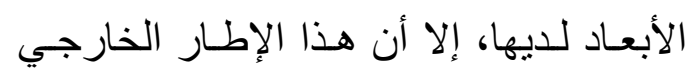

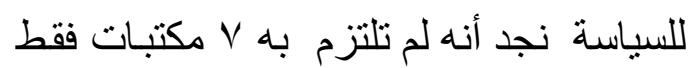
من 79 مكتبة بنسبة • 1 \% ؛ ؛ حيث أغفلت

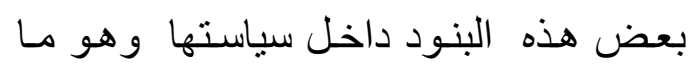

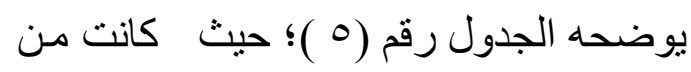
نصيب الو لايـات المتحدة ثنلاث مكتبـات من لن

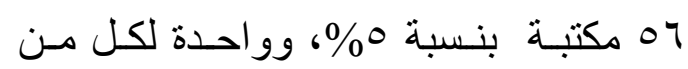

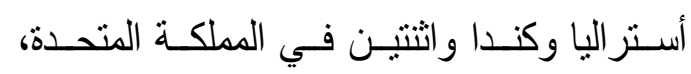
وبالتـالي فالو لايـات المتحدة وفرت سياسـة ناضجة

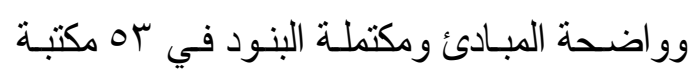

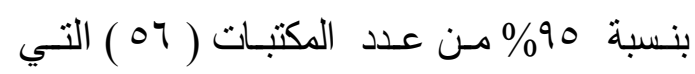
وفرت سياسات داخل جدر انها، ولذلك فإنها 
بندين، هما : بند تحديد الفترات الزمنية لتقديم

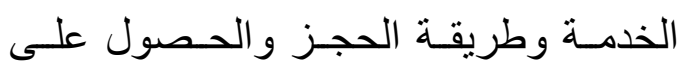
المخرجـات ، ثم بنـد تكلفـة الخدمـة وطـرق تحصيلها واستردادها؛ حيث أتيحوا فقط في ـ7 مكتبـة من 79 مكتبـة أي مـا يمثنل نسبة وهنة .$\% 94$

هـذه الفقـرات الـسابقة كانــت عرضنَّا لـشكل الإطـار الخـارجي أو القالب التي اعتمدتهـ مكتبـات العالم لسياستها، وعن أهم البنود التي التزمت بها جميع المكتبات و وعن البنود التي أغفلتها مكتبات

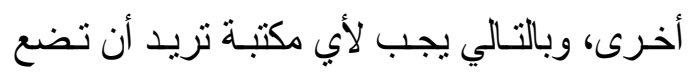

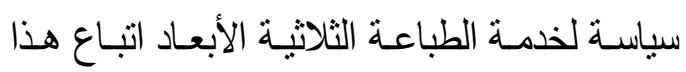
الإطار ومحاولة الالتز ام به.

على الرغم من أن بآمكتبة اتفقت على تحديد

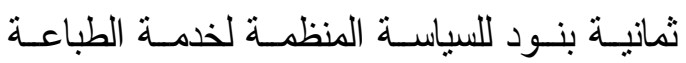

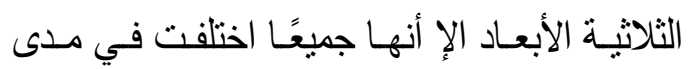
التفصيل أو الإيجاز في محتوي هذه البنود، فعلى الرغم من أن هنالك مكتبات اكتفت بسطر سياستها في ورقتيـن على مو اقعها، إلا أن هنـاك مكتبـات أخـرى أدرجـت سياسـتها في عـشر ات الأوراق تحوي بجانب نص السياسـة صـورًا للأجهزة التي

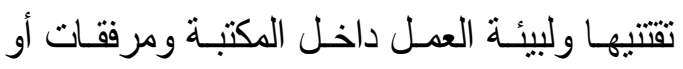
ملاحق باسـتمار ات طلب الخدمـة، فمنهـا مـن قـام

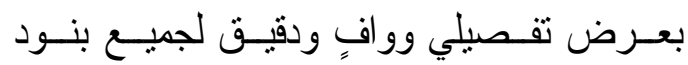

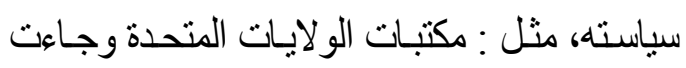
بعدها كندا إلا أن أستر اليا و إنجلترا أثنـارنا للبنود بايجـاز فـي محتـوى سياسـتها مقارنـة بسياسـات
توجيهيـة لـضضمان الحقـوق القانونيـة وعوامـلـ الأمن و السلامة؛ حيث رأت المكتبات أن جو هر ور سياسـة الخدمـة يكمن في توفير هـذه العناصـر

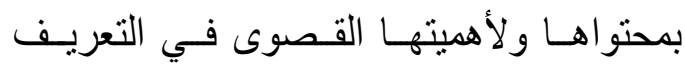
بالخدمة المقدمة ولضمان الحقوق وتيسير عمل

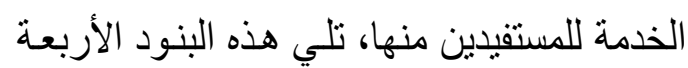
مبـدأ (مواصــفات الأجهـزة والمقـاييس النهائيـة التي يكون عليها المخرج المطبوع)؛ حيث أتبح

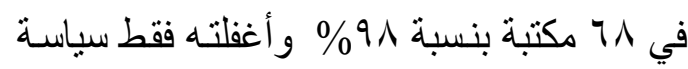
واحـدة فـي أسـتر البا، هـي : المكتبــة العامـة فئة

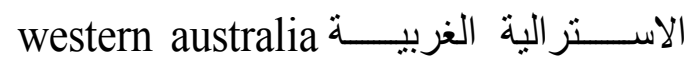
public library

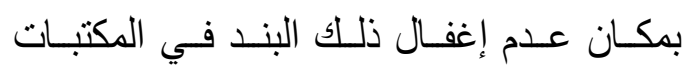
العربية ؛ لأنه يحدد للمستفيد مو اصفات مخرجها الذي يريد رؤيته بشكل وجودة معينة، أمـا مبدأ

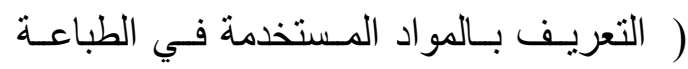
وألو انهـا ) فقــ تكـرر في بـ 79 مكتبـة مـن 79 مكتبـة بنسبة و9\% و وأغفلته فقط ثنلات مكتبـات جامعيـة في الولايـات المتحـدة، هـي : مكتبـات جامعسـة كولومبيــا Columbia University libraries ، ومكتبـة جامعـة مـاري في و واشنطن The University of Mary Washington أورجــون Valley Library Oregon State University ثم جـاء في المرتبـة الأخيرة كأقل البنود

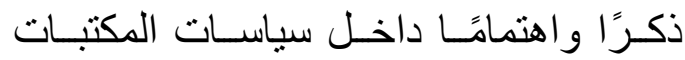




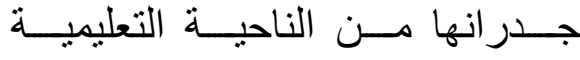
و الترفيهيـة ، فتتـص مثـلا المكتبـات المدرسية و الجامعية على دعم الخدمة

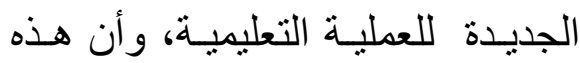
التكنولوجيا ما هي إلا مصدر معلومـات

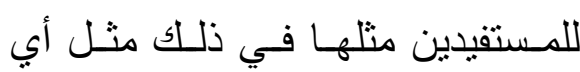
مصدر معلومات بالمكتبة، فتساعد تللك ملك الخدمة في التفكير في الأمور العلميـة

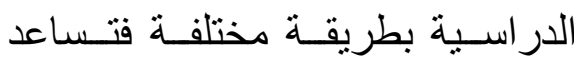

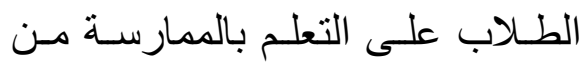

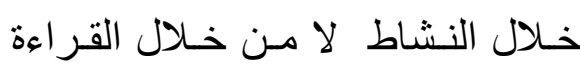
و الحفظ و التلقين؛ مما يسهم في تربيـة جيل جديد قادر على القيادة من خـلال

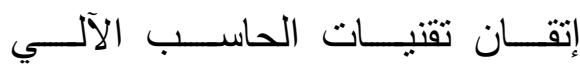
و التكنولوجيا الحديثة وتشجعيهم على التفكير بـشكل حـر، هـذا بالإضـافة لعـرض دور الخدمـة الترفيهـي الـذي يتمتع بـه المستفيدين في بيئة الصنع هذه ، وتتص المكتبات العامـة على أن الغرض من توفير الخدمـة في المكتبـة هـو مـن أجـل تقـديم خدمــة أفضـل فئل للمستفيدين، وتوفـير حـق الوصـول للجميع بنفس القدر من المساواة بين أفر اد المجتمع مع إتاحة فرصة الإبداع والابتكــــار والـــصنع و المــشـاركة التعاونية لأفر اد المجتمع ومحو أميتهم التكنولوجيـة، مـن خــلال اســتخدام
الو لايات المتحدة وكندا. وبالنظر إلى منون تلك السياسـات والمبادئ التي

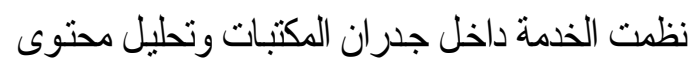
بنودهـا بشكل تقصيلي، رأت الباحثة أنه يجب على لفى

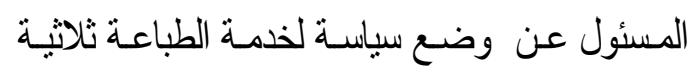

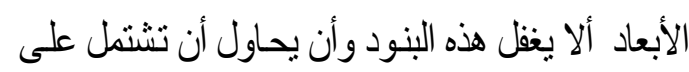
جيع عناصر ها الفرعبة التي تعطي معلومـات أكثر عن الخدمة وتنيح للمستفبدين الثكل الأكمل الذي يجب أن تكون عليـه سياسـة واضـحة ومفصلة، وحاولت

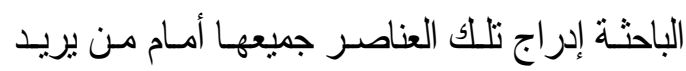

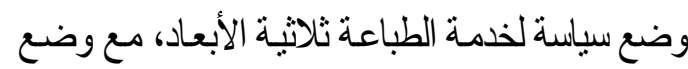

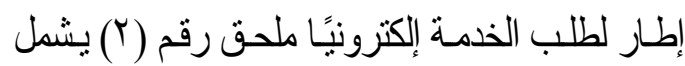
معظم البنـود التـي تـم إدراجهـا فـي كـل مرفقـات السياسات الأجنبية وهو من إعداد الباحثة، والآن يمكن عرض لمحتوى الأسس التي يجب أن تتبعها المكتبات العربية عند وضعها سياسة للخدمة وهو مـا جاء نتيجة لتحليل منون السباسات الأجنيية. بـ الأسسـس الـتي يجـب أن نكسون عليهـا محتوى السياسات العربية للخدمة:

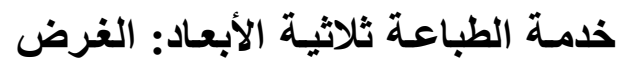
والتعريف: • التعريف والتوعيـة بـالمعنى الاصطلاحي للطباعـة ثلاثيـة الأبعـاد، وكذللك التعريف بـ

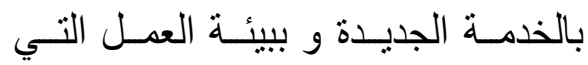
تثو اجد بها الطابعات الثناثية الأبعاد.

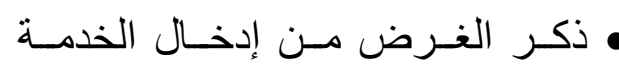

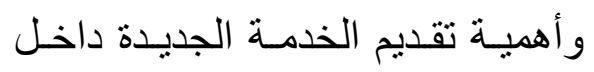


و الكلية أولَا أم سيتعامل الطلاب بشكل

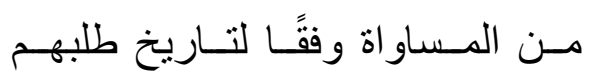
للخدمة.

ثرديد الفئـات التي لها حق أمر طباعة

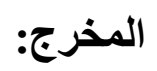

ويتـضمن هــذا المبـدأ ذكـر القئـات المسؤولة عن الطباعـة ( المستفيد الموظف ). فبعض المكتبات تنرك مسئولية الطباعة على المستفيد،وبعض المكتبـات لا تتيـح للمستفيد طباعـة مخرجـه بنفسه؛ و تؤكد على أن تكـون مسؤولية الطباعـة مـن اختصاص الموظف وليس المستقبد أيًا

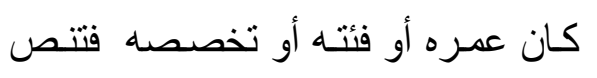
على ذلك بوضـوح داخـل السياسـة في إثـارة منهـا لأسـباب ذلك، أنسه تحقيقًا لعوامـل الأمسن والـسلامة لمستفيديها، وممكن للمكتبـات العربيـة إضـافة قدر من المرونة من خلال وضـع بند، يوضـح

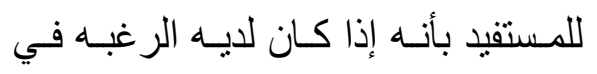

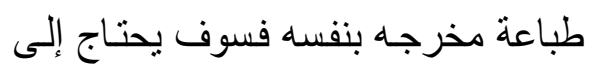
تقديم استمارة بطلب ذللك الأمر، ومن ثم تقوم المكتبة بتحديد موعد لله مـع موظفي

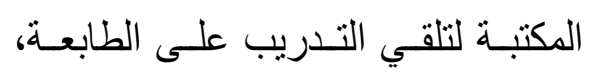
وذللك تحت إثر اف ومتابعة الموظفين. ض ضـرورة أن تـذكر المكتبـات ــ التـي تترك للمستفيد مسئولية الطباعة بنفسه
ومشاركة الأجهزة الحديثة فهو هدف المكتبات الأول في هذه المجتمعات. الفئات التي لها حق الاستخدام والطباعة: انقسم هذا العنصر داخل معظم السياسـات إلى ثلاثنة عناصر ، هي: هـ تحديد الفئات التي لها حق الاستخدام: • تحديد الفئات و الجمهور المقدم لهم الخدمـة، وهـل تقـدم الخدمـة لجميـع الفئات أم تقدم لفئات بعينها ؟ فمثلًا في وهي المكتبـات الجامعيـة يذكر : هل ستقدم

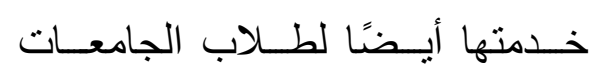
الأخرى بجانب طلابها أم لا.

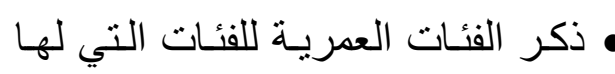
حـق الاسـتخدام ، فمثنًَ المكتبـات العامة المتاحة للجميع هل ستتيح خدمة الطباعة للأطفال.

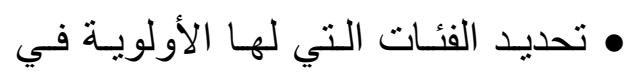
الاستخدام، فيجب أن تشرح السياسـة بدقة من يتقدم عمن في أولويـة الحجز

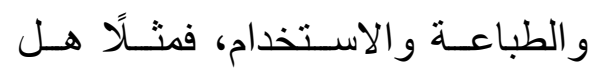
يقدمون خـدمتهم أولًا للطـلاب الذيـن يطلبـون الخدمـة لمسشاريعهم البحثيـة وللار اسـة، أم الذين بطلبـون خدمتهم

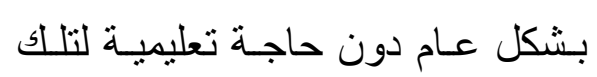
المخرجات، وكذللك عند تقديم الخدمـة لطلاب الجامعات الأخرى يذكر : هل سـتعطي الأولويـة لطـلاب الجامعـة 
وتضع بعض المكتبات في هذا المبدأ

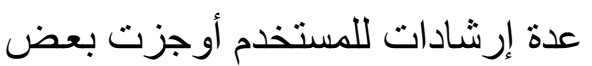
المكتبات فيها وفصلت بعض المكتبات

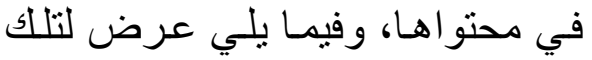
الإرشادت التي اتفقت عليها وفصلتها بعض السياسات: أـ تحدد المكتبـة للمستفيد مثنلً صبيغة الملف المطلـوب طباعتـه، مثلـل :

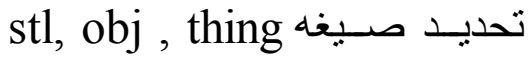
كصيغه رئيسية لملفاتها، وفي حالة المخالفة ينم رفض استمارة الحجز وتحدد المكتبة حجم الملف، فلا يزيد عن حجم معين من الميجا بايت.

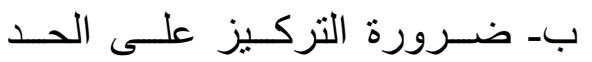
الأقصىى لحجـم الملفـات؛ والتــي حددت في مو اصفات الطابعة نفسها و إلا سوف يتم رفض طلب الخدمة. ج- ضــرورة اسـتخدام و مراجعـة بعضض فئل البرامج التي تساعد المستفيد في إصلاح

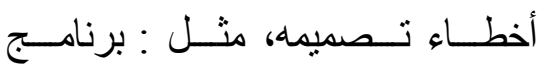
لتجنـب كثير مسن (NETFABB) أخطاء الطباعة للمخرجات. دـ يمكن استخدام عدد من التصميمات

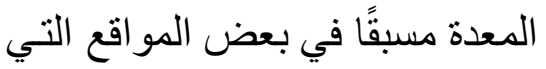

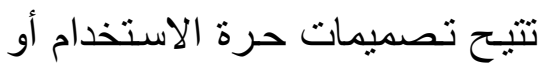
تــصيمات لأول مسـرة، منــل: Sketchup, Blender,
ـ أنه إذا كان لديه أي رغبه في طلب المساعدة من قبل المكتبة أو أنـه ليس على علم كافٍ بالعملية برمتها، و أنهـ بحاجـة إلى مساعدة موظفي الخدمـة فإن عليه تقديم استمارة طلب مساعدة ومر اسلة المكتبة، (ملحق رقم ؟).

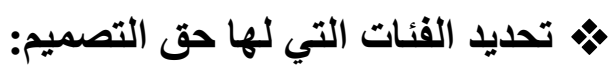

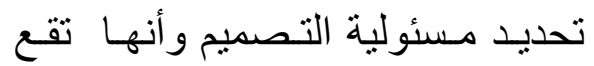
على كاهـل المستقفيد فقـط، فعلـى المستقفيد إنشاء تـصميمه أو مسسحه

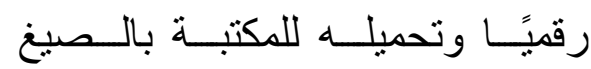

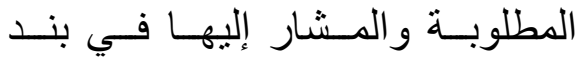
إجر اءات طلب الخدمة. ذكر الأجهزة والبرامج المتوفرة بالمكتبة،

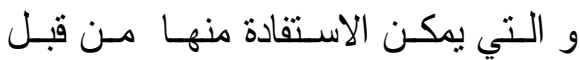
المستفيد في عملية التصميم كالماسحات التحات الضوئية ثلاثية الأبعاد، وكذلك البرمجيات القانونيـة المرخصة من بـرامج الأوتوكـاد و الفوتوشــوب؛ والـتي يمكـن اســتخدامها لإنشاء أي تصميم يحتاجه المستقيد.

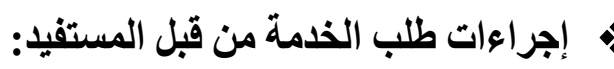

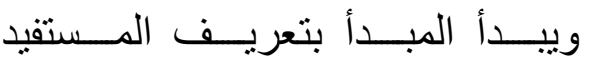
بـالخطوات التي يجب أن يقوم بهـا طالب الخدمـة مـن المكتبـة بدايـة مـن طلب حجز و تعبئة استمارة تفي بكثير مـن البيانـات المطلوبـة لـدى المكتبـة، الملحق رقم (r). 


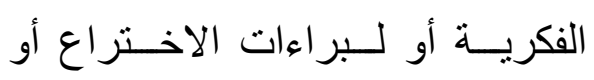
للعلامـات التجاريـة أو لحقوق الطبـع

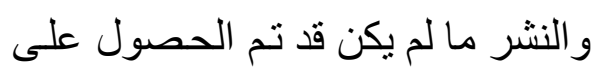
مو افقة المالك. • لن يسمح بطباعة محتوى من أي مواد

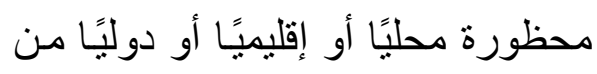

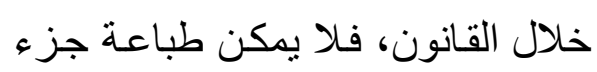
من سلاح أو سلاح كامل. • لا تـستخدم الخدمـة لطباعـة الأمسور الفاحشة، و غير اللائقة و المنافيـة لبيئة

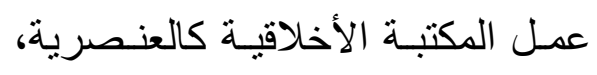
و العرقيــة، و المهـــددة، و المــــيئة، و الضارة بصغار السن. ، لا تستخدم الخدمة في طباعة مخرجات عضوية طبية إلا تحت إثـر اف الجهة البحثية. • لن يتم قبول طباعـة كميات من النسخ من نفس المخرج بنفس المكتبـة لأن غرض الخدمـة تعليمي تثقيفي إبداعي لا للأغر اض الإنتاجية.

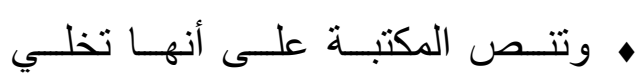
مسئوليتها عن كيفية استخدام المستفيد النهائي للمخرجات المصدمة. غناصر الأمن:

• توضيح أنه لا يمكن للمستفيد ملامسة الطابعات بعد وضعها قيد الاستخدام.

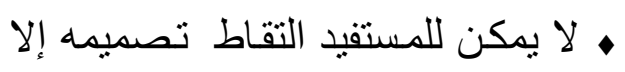

Opencad, thingiverse و البعض يحذر من استخدام بعض البر امج بعينها ؛ لأنه لا بتم طباعة

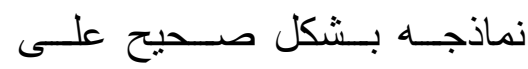
الطابعات و التي من أمثلتها موقع .Sketchup • تلتزم المكتبات في هذا المبدأ بأنسه سيتم

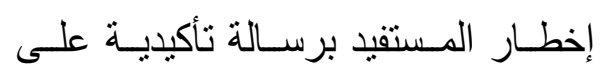
بريده الإلكتروني باستلام طلبه و المو افقة

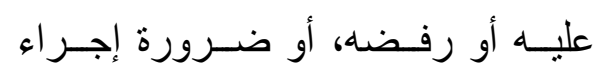
تعـديلات عليـه أو أن هنــاك عـدة أمـور

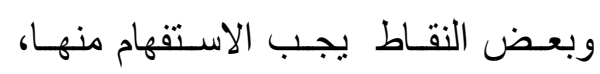
والتشاور مـع الموظف بشأنها، أو إبلاغه

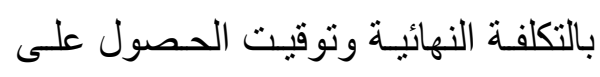

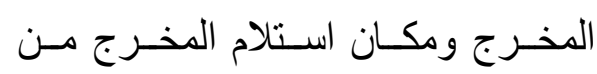
المكتبة، انظر الملحق رقم (r).

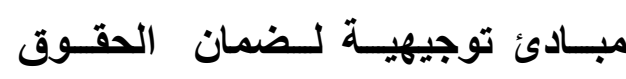
القاتونية وعناصر الأمن والسلامة: مبادئ توجيهية: • تـذكر فيـه المكتبـة حقهـا الكامـل في في في رفض طباعـة أي طلب وفقًا لتقديـر موظفي المكتبـة، وأنـهـ يتـم اسـتخدام

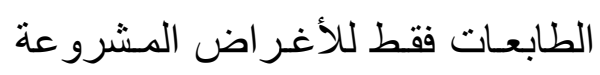
ومسن الأمثلــة علـى بعـض الأمسور المرفوض طباعتها: • لن يتم السماح بطباعـة محتوى غير فير

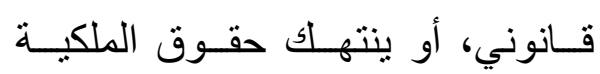


مو مواصفات الأجهزة والمقاييس النهائية التي يكون عليها المخرج المطبوع:

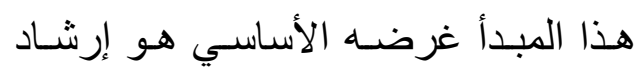

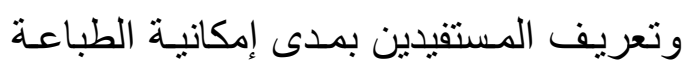

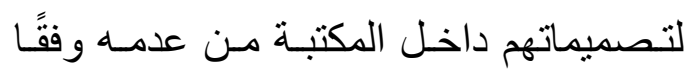
لمواصفات الطابعات المقتناه بالمكتبة أم عليه

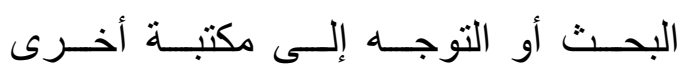

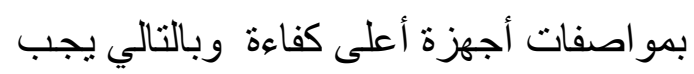
ذكر ما يلي:

• مو اصفات الأجهزة، مثل: نوع الطابعات

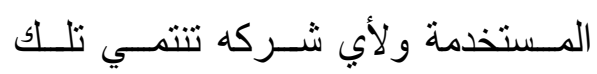
الطابعات، وأي إصدار تستخدم.

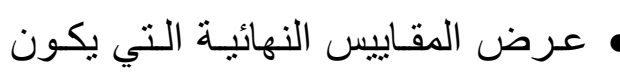

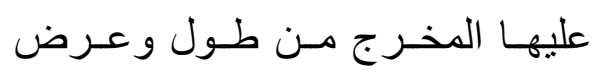

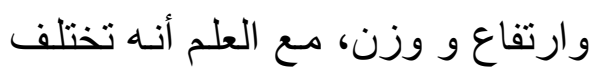

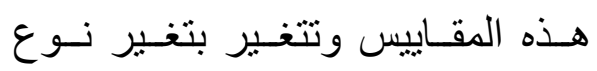
الطابعة المستخدمة داخل المكتبة، المواد المستخدمة في الطباعة و ألوانها:

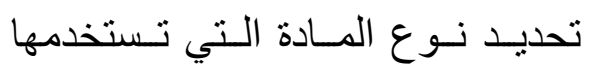

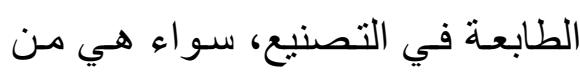
البلاستيك الحراري أو غير ذلك من الكن هن

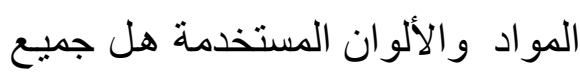

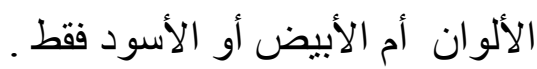

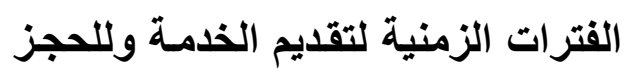
وللحصول على المخرجات:

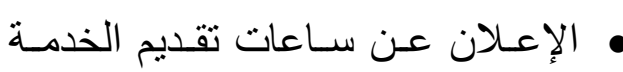
بالمكتبة وأوقات الصبانة والعطلات،
بو اسطة موظف الخدمة تجنبًا للحروق وللإصابة.

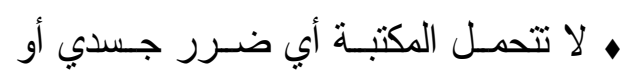
إصابات ناتجة من استخدام تلك الطابعات. هبادئ إرشادية عامة:

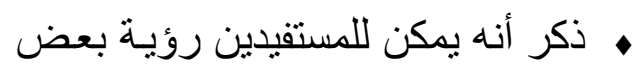
العيوب الطفيفة في المخرجات لديهم

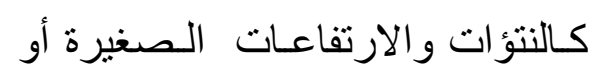
الخشنة في حواف المخرج، ويمكن

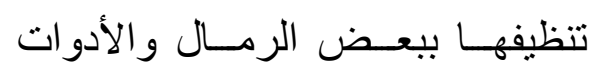
الخاصة لذلك. ه الإشـارة إلى أن هناك انبعاث لروائح

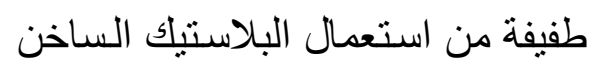

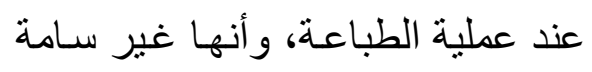
ولكن يمكن أن يكون ذلك مصدرًا للإِز عاج، ويجب في الحقيقة مر اعاة

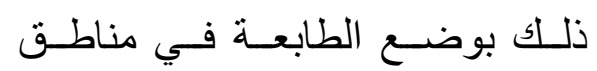
مفتوحة بالمكتبات و بالقرب من أماكن التهوية الطبيعية والصناعية.

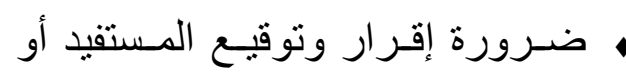

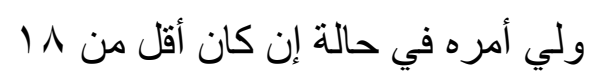
سنة بالمو افقة على المبادئ المذكورة بعاليه، وأنسه في حالـة عدم الامتثال لهذه البنود المذكورة سيؤدي إلى عدم حلى النه

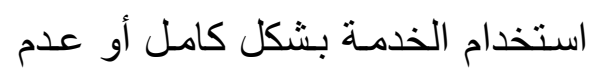

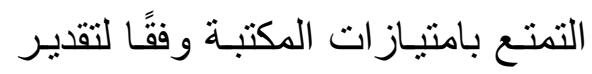
موظفي المكتبة. 
تحديد فتره زمنية لحذف جميع الملفات

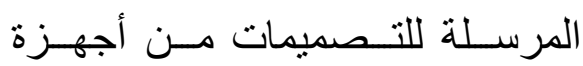
الكمبيوتــر بالمكتبــة و إلغائهـــا مــن الطابعات ولوحاتها الإلكترونيـة، وأنه لن يتم الاحتفاظ بها و لا يمكن استعادة تلك الملفـات الرقميـة بعد الحصول على المخـرج بفـترة زمنيـة محـددة، وعلى المسستفيد مسسئولية الاحتفـاظ

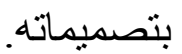

تحديد عدد مـرات الاستخدام لخدمـة الطباعة لكل فئة من المستفيدين منها؛ حيـث يمكن لفئة دون غيرهـا تكرار الطباعة في اليوم الواحد أو الأسبوع

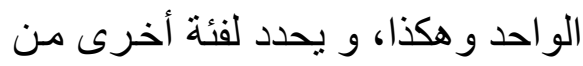
المسـتفيدين أنــهـ لا يمكـن تكــرار الطباعـة إلا بعـد مـرور فـترة زمنيـة محددة، حيث يحصل عليها أكبر عدد إلاد بعد رمد من المستفيدين.

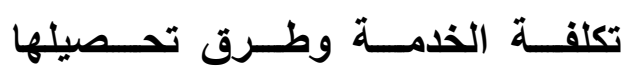
واستردادها: في حالة تقديم الخدمة بتكلفة تذكر بند

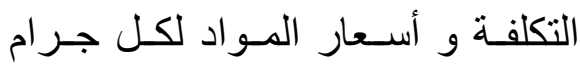
و الذي يتحدد وفقًا لزيادة معامل الجودة و الدقة أو الجهاز المستخدم. يتم ذكر أنسه في حالة عدم رضـا المستفيد

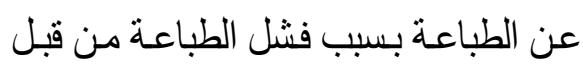
الموظف أو حتي لو كانت الطباعة تحت
تحديد وقت الحصول على المخرج لكل مستفيد على ألا يتجـاوز الأسـبوع، وذلك مـن يـوم طلب المستقفيد للخدمـة ومو افقـة المكتبة على طلبه، ثم يذكر اليوم و الوقت ومت موت

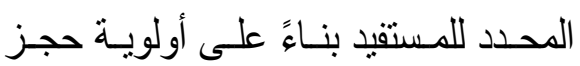
المستقفيد داخـل المخطـط الزمــي للخدمـة بالمكتبـة، مـع ضـرورة الإثــارة إلـى أنـهـ

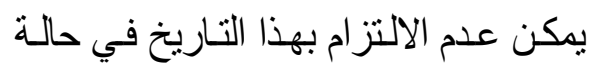
إذا كان بالمكتبـة عدد من طلبـات الطباعـة التي تجبرهـا على مـد هـذه الفـرة وفقًا لجداول الانتظار، وتثير إلى أنه في حالة حدوث ذلك سيتم إعلام المستقبد بذللك من الن

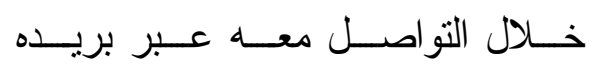
الإلكتروني. وضـع تنويسه للمستفيدين بـأن المكتبـة

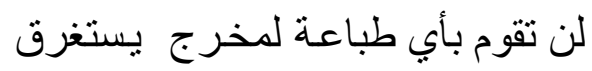

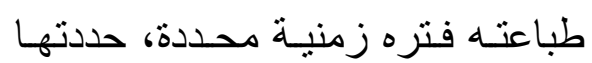
معظـم المكتبـات فيمـا لا يتجــاوز طباعته أكثر من خمس سـاعات لأن الطباعة تستغرق وقتًا طويلاً. تحديـــــرة زمنيـة لاسـتلام المخـرج النهـائي تـتراوح بيـن الأسـبوع إلـى

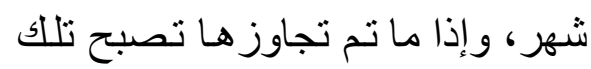

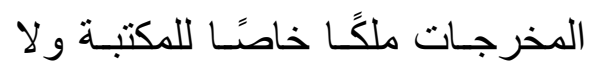
يحـق للمستقفيد طلبهـا، ويسسقط حـق ملكيته للمخرج وللتصميم إذا تخطت

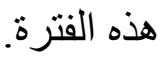


عاشرًا : نتائج الدراسة:

ا - فرضت خدمة الطباعة ثناثية الأبعاد نفسها على المكتبات في سنو ات الأخيرة، كثكل جديد من الخدمات التكنولوجية التي تقدمها المكتبات؛ وذلك استجابة لاحتياجات المستفيدين ولاحتياجات

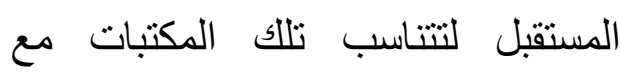
التطور الدائم لتكنولوجيا المعلومات، ففكرة سد الفجوات الرقمية، وملاحقة

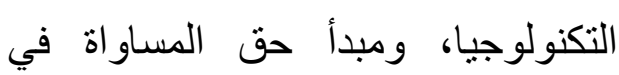
الحصول على تكنولوجيا المعلومات للجميع كانت الدافع وراء المكتبات لإتاحة الخدمة.

r- بدأت إتاحة خدمة الطباعة ثلاثية الأبعاد في المكتبات بعد ؟r عامًا من نشأة هذه الأجهزة

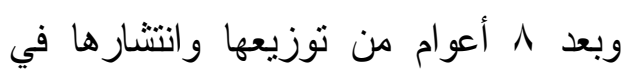

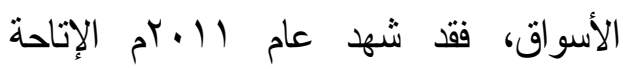
الفعلية لخدمة الطباعة للمستفيدين، وأدت هذه الاتاحة لظهور سياسات وبيئة عمل جديدة لم تشهدها المكتبات من قبل تقنن وتُقدم الخدمة من خلالها. ץ- لم تتح أي مكتبة وطنية على مستوى العالم خدمة الطباعة ثثلاثية الأبعاد لمستفيديها حتى وقت انتهاء حصر التهر الباحثة للمكتبات، وتميزت عنها المكتبات العامة في كونها أكثر المكتبات تطبيقًا للخدمة داخل المكتبات محل الدراسة فئ لهن
إثر افه مع دقة التصميم من قبل المستفيد، واتباعـة كافـة التعليمـات الإرشـادية، سـيتم إعادة طباعة المخرجـات دون تحمل تكلفة ذلك من قبل المستفيد إذا كانت الخدمـة تقدم بمقابل مادي. تحديد طريقة الدفع : نقدًا أو بشيكات أو ببطاقة ائتمـان ومو اعيد تحصيلها قبل أم بعد الخدمة. تحديد حالات استرداد التكلفة للمستفيد، بعده مثل : حالة كسر المخرجات - أو خطأ الموظف في حالـة الطباعـة مـن قبـل الموظفين. في حالة تقديم الخدمة بصورة مجانيـة يتم توضـيح هـل هـذه المجانيـة لفئة

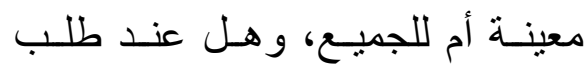
طباعـة لمـرة واحـدة أم أكـثر؛ لأن فئن البعض قدم الخدمة مجانية لأول طلبين

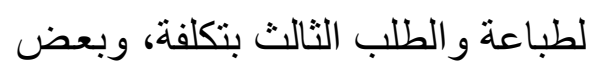

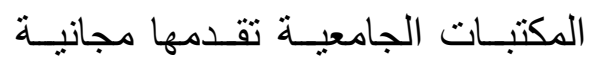
لطلابها داخل مشناريعهم العلميـة التي تتطلبها الدر اسة، ويتم ذلك من خـلال مـله نمـوذج موقع مـن عضو هيئة التدريس المسئول عن فريق العمل أو مون فئ هون عن المشروع البحثي. يمكن ذكـر ممـول الخدمـة إذا كانـــ

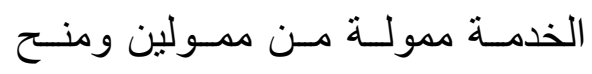
خارجية ومدة هذه المنح. 
T- جاءت الطابعات جاهزة الصنع كأكثر الطابعات استخداءًا داخل المكتبات فلم المات المنات يلجأ إلا ثلاثة مكتبات لاستخدام الطابعات

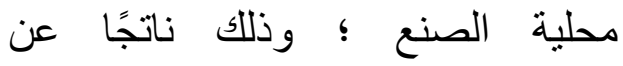
إنضماهمج إلى مبادرات إتاحة الطابعات

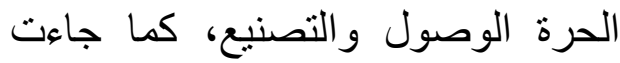
الأجهزة ذات الصناعة الأمريكية كأكثر الوحر الأجهزة استخدامًا داخل المكتبات محل الدراسة، حيث استحوذت طابعة ماكر بوت بإصداراتها و واجيالها المختلفة

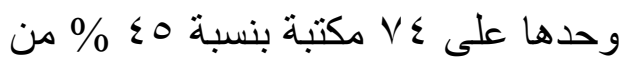
إجمالي المكتبات على مستوى العالم.

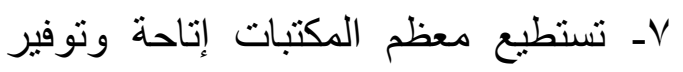
خدمة جيدة لطباعة ثلاثية الأبعاد لمستفيديها من خلال اقتناء طابعة واحدة فقط داخل جدر انها؛ حيث استطاعت 19 مكتبة بنسبة 00 \% من إجمالي المكتبات محل الدراسة نوفير خدمة جيدة لمستفيديها

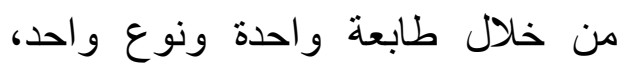

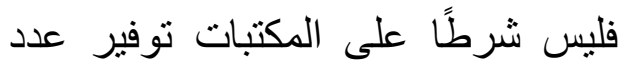
من الأجهزة لتقايم خدمة أفضل.

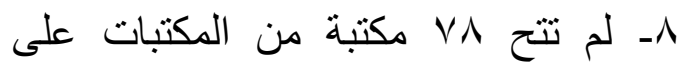
مستوى العالم بنسبة هی

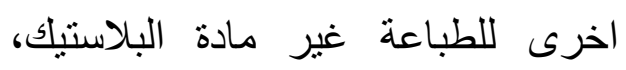
واتبعت 01 مكتبة منهم معايير الأمن والسلامة الخاصة بصحة الإنسان عند الئان اختبار ها للمو اد الخام للطباعة، فاختارت
فساهمت بنسبة ع \% من إجمالي

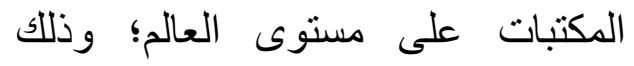
لتبنيها هدف إتاحة العلم والمعرفة عن العنات طريق الممارسة والتجريب من خلال الأجهزة، وتلتها في تحقيق ذلك المكتبات ولنجات الجامعية بفارق عددي كبير وبنسبة تصل

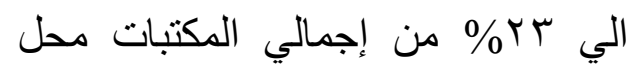
دراسة. - ائ

عـ توفرت لخدمة الطباعة ثلاثية الأبعاد بيئة

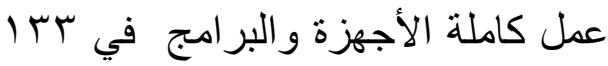
مكتبة بنسبة r^\% من إجمالي المكتبات

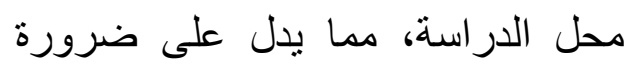
مراعاة توفير وتجهيز مكان مناسب للخدمة وملحقاتها بالمكتبات العربية. ○ـ حظت جميع الككتبات محل الدراسة بالدعم الكافي و التمويل الجيد للخدمة من النمات

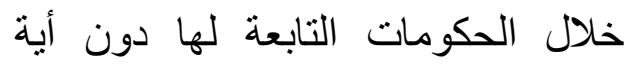
قيود، و تميزت 0؛ مكتبة منها بنسبة

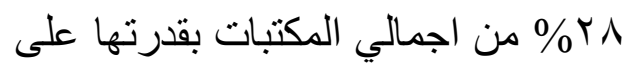

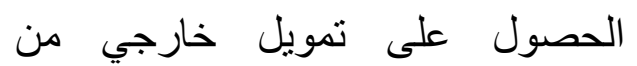
مؤسسات خاصة ورعاة للبحث العلمي، وذللك لدعم الخدمة و إتاحتها بشكل أفضل لمستفيديها عن طريق : تحمل كامل

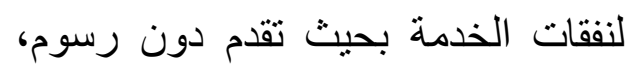
وشراء أجهزة ذات مواصفات وجودة أعلى وبأعداد أكبر، وتوفير ألوان متعددة دوات وجنات

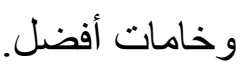


لمستفيديها أية مبادئ معلنة لاستخدام

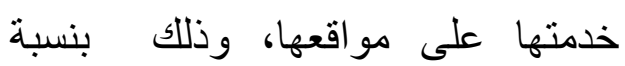
.$\% \circ 1$

11 - وضعت ب7 مكتبة من بين 79 مكتبة من المكتبات التي أعلنت عن سياسة لخدمتها علي مستوى العالم سياسة محددة ومكتملة البنود لسياستها المنظمة للخدمة، واتفقت على أن الن سياسة الخدمة يجب أن تشنمل على ثمانية

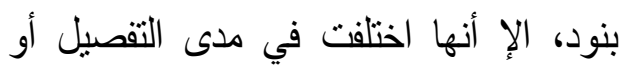
الإيجاز في محتوي هذه البنود، فأدرجت بعض المكتبات محتوى سياستها في ورقتين على مواقعها، في حين أدرجت مكتبات أخرى سياستها في عثرات الأوراق، وخرجت الباحثة هن خلال تحليلها لهذه السياسات، بأهم الأسس التي يجب ان تكون عليها سياسة للخدمة بالمكتبات عربية. الأحد عثر: توصيات الدراسة: ا ـ توصيات موجهة للاولة والقطاع الخاص: أـ ضرورة إدرالك الدولة أن هذه التكنولوجيا أعطت للعالم ثورة صناعية جديدة وأن مثل إنل هذه التكنولوجيا ومنتجاتها الصناعية تنمو يومًا بعد يوم، ولذللك يجب على الدولة مواكبة تطور هذه التقنية ثلاثية الأبعاد من لنابل خلال تذليل العقبات التي تقف في سبيل انتشار هذه التقنية وذلك من خلال: • بحث سبل تخفيض أسعار وجلب تللك هن الآلة الرائعة لتصبح مناحة للجميع
لذلك مادة البلاستيك PLA الآمنة على حياة البشر وبيئته. 9- اتفقت AV مكتبة من إجمالي المكتبات بنسبة \%or\% على أن التدريب هو عنصر هام لإدخال هذه التكنولوجيا داخل المكتبات، و واتفق الجميع على هُم ضرورة تدريب العاملين على التفاعل الجيد مع الأجهزة و الرد على أسئلة المستقبدين التي بمكن تلقيها، وذلك قبل الاهيل إناحة الخدمة للمستفيدين و الإعلان عنها بشهور، بينما اختلفت المكتبات محل واعل

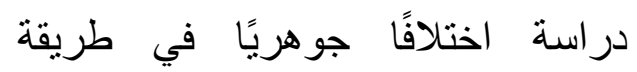
تدريبها للمستفيدين سواء في محتوى هذه الدور ات أو في مدة انعقادها أو في تكرار

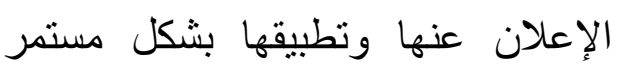
ودوري على مدار العام. • 1 - تبنت 79 مكتبة من إجمالي المكتبات بنسبة بع\% سياسات عمل تحكم الخدمة وتحدد إجراءتها، وأعلنوا عن مبررات قيامهم بذلك في: أن إدخال خدمات جديدة بالمكتبات دون الإدارة السليمة لهاب لهاب ودعمها بالسياسات، سوف يؤدي إلى بلى

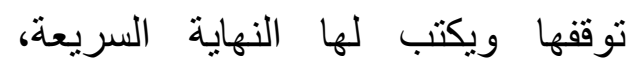
وتركز ذللك العدد في أربع دول فقط من احدى عشرة دولة قدمت الخدمة، و وعلى الرغم من أهمية الأمر إلا أنه لم تعلن

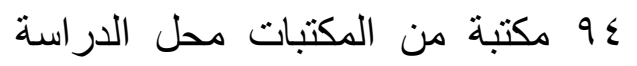


مجال التعليم، فهي قادرة على توفير أدوات أفضل للطلاب: (خرائط مجسمة، أعضاء جسم مجسمة، نماذج مجسمة للمركبات الكيميائية، نماذج أولية لمشاريع الطلاب)

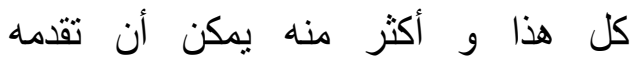
تكنولوجيا الطباعة ثلاثية الأبعاد في كافة المؤسسات التعليمية أو من خلال المكتبات

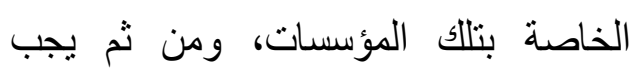
استثمار هذه التكنولوجيا وخدماتها

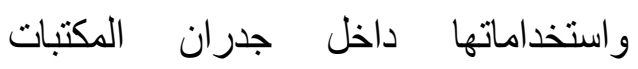
العربية، فالتعليم لا يأتي بالحفظ والتلقين

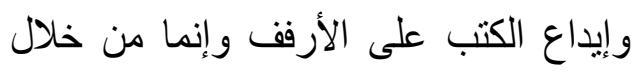

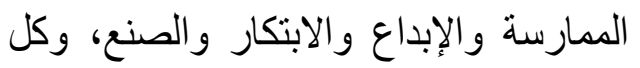

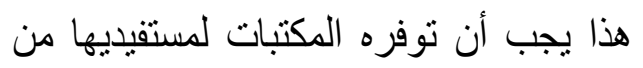

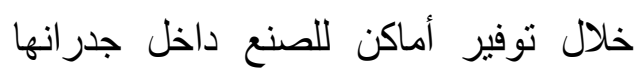
تحتوي على الآلات الخاصة بذلك.

بـ ضرورة مواجهة التحديات التي يمكن أن الن لأل تعرقل إدخال هذه التكنولوجيا والخدمة

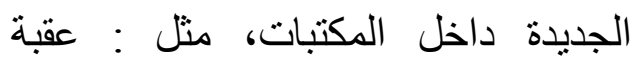
الميزانيات، و إمكانيات تدريب الموظفين القادريين على تطويع هذه التكنولوجيا

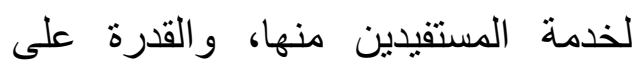

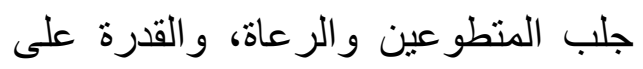

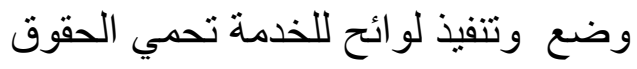

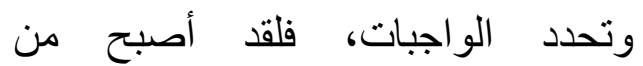
الضروري تخطي هذه التحديات على فلى لفيح الأقل في الككتبات الوطنية و الجامعية.
بعيدًا عن احتكار الثركات الكبرى و هذا يمكن للاولة من خلال الاشتراك الك في عدد من الاتفاقيات و المبادرات التي تتيح هذه التكنولوجيا بمبالغ مخفضة، وتتيح صنع هذه الآلة نفسها بنفسها ضمن قو انين وضعت لذللك. بحث سبل تمكين المنتجات الصناعية

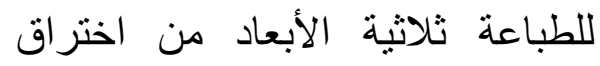
الأسواق و منافسة المنتجات المصنعة بالطرق التقليدية، بـ ضرورة رعاية هذا النشاط الاقتصادي

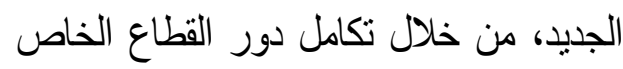

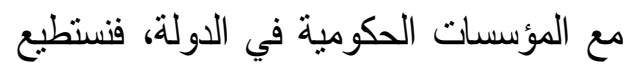
من خلال القليل من التمويل الخاص أن نمثلاك

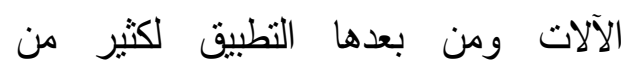
المشاريع في كثير من المجالات وخاصة العلمية؛ وهو أثند ما نحتاج إليه في هذه الأيام لتخرج دول العالم العربي من هذه الكبوة

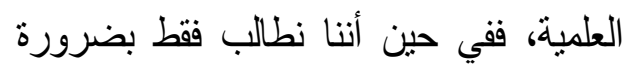
النظر إلى قيمة الطباعة ثلاثثية الأبعاد وتمويلها هناك من بيسي لإضافة بعدًا رابعًا

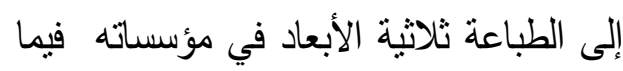

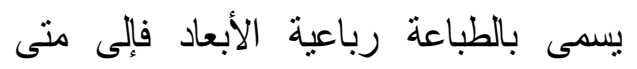
سنظل نقق لنشاهد من بعيد. r - توصيات موجهة للمكتبات:

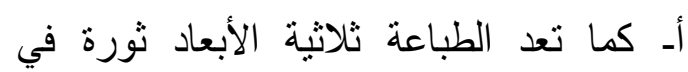
مجال الصناعة؛ ولذلك فهي ثورة أيضًا في تُوني 


\section{يمكن أن تتعـرض لهـا المكتبـات جـر اء استخدام تلك الطابعات؟ قائمة الاستثهادات المرجعية:}

1. Hogan, P، (January 24, 2013)، rd printing in libraries: inspiration or distraction ، Retrieved from http://www،alatechsource‘org/blog/2013/01/3d-printing-inlibraries-inspiration-or-distraction'html

2. Gutsche, B، (November 07, 2012 )، rd printers: a revolution headed for your library 'Retrieved april, 2013, from http:// www'webjunction‘org/news/webjunction/3D_Printer_Revolution‘html

3. Lacey, G، (Sep 2010)، Get students excited 3d printing bring designs to lifer Tech Directions, 70( 2), p17,18 ،

4. Denison, D، (December 11, 2013 )، rd printer access، Make: Magazine maker pro newsletter، Retrieved from http:// m a k e z i n ercom/2013/12/11/maker-pronewsletter-111413/

5. Gallant, R، (April 22, 2013)، rd printing in libraries around the world ، $r \mathrm{D}$ printer and 3D printing news 'Retrieved from http:// w w wr'd e r s‘org/articles/20130422-3d printing-in-libraries-around-the-world‘html

6. Global, T، (nov 2013)، Makerspaces [wikispaces] ‘Retrieved from http:// youthserviceslibrarianship‘wikispaces‘com/ Makerspaces

7. Michigan, D، L، U، o‘) ‘Libraries \& Maker Culture: A Resource Guide Makerspaces in Libraries Retrieved jan 2014, from http:// um3d`dc‘umich‘edu/

8. Lisa Kurt , T ،C ) (July 17, 2012 ) ‘3d printers in the library : toward fab lab in the
ج- تجنب السلبيات التي تأتي من إدخال هذه التكنولوجيا داخل المكتبات، وذللك من خلال: توفير بيئة آمنة وغير ضارة للمستخدمين، ومن خلال اختيار جيد لمواد الصنع و البناء بتلك الطابعات، واختيار جيد لمصادر التهوية والإضاءة، ولأماكن تشغيل الطابعات بحيث تكون بعيدة عن قاعات الإطلاع مع تطبيق جيد

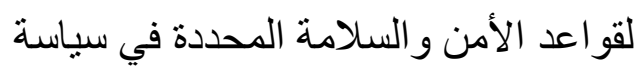
استخدام الخدمة. بـ توصيات موجهة للباحثين:

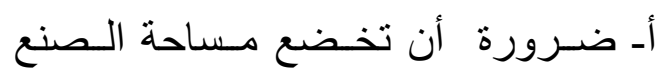
والابتكار داخل المكتبـات لعدة در اسـات مستقبلية مـن قبـل البـاحثين العرب لنقل

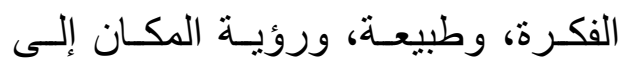

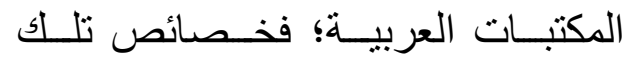

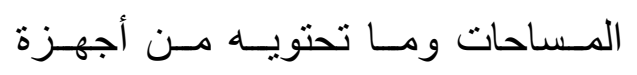
وخامـات جديرة بأن يفرد لها در اسـات مستقلة لكل منها على حدة.

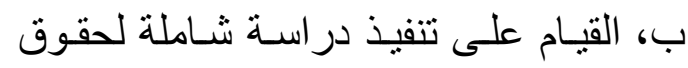

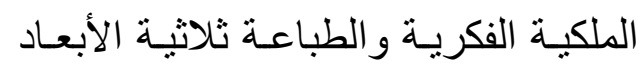

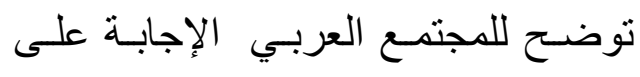
التساؤلات التالية: هل هناك انتهاك لبعض البه

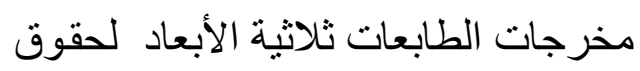

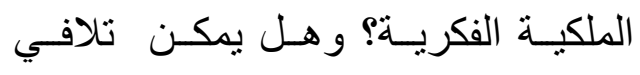
المكتبات للأمور الخلافيـة والقانونيـة التي 
2012) ‘Searcher magazine, 20( 8), 9 p ، Retrieved from http://connection'ebscohost /product-reviews/80919156/ implications-3d-printing

22.Hart, B) ‘Mar 11, 2014) ‘Will 3d printing change the world? 'Laissez Faire Today 'Retrieved from http:// lfb،org/will-3-d-printing-change-theworld/

23. The implication of $3 d$ printing ، Op،Cit , 9 p،

24.Loc، Cit ،

25.bobbie, J، (5/14/2011) "rD Printing، New Scientist, 210 (2812), 32 p، Retrieved from http://connection'ebscoh o s t،com/c/articles/61033061/3d-printing 2812

26. Hart, B ‘Op،Cit

27. Berman, B، Op،Cit, 158 p ،

28. Gutsche, B، Op،Cit

29. How to Build 3D Printer? $\ulcorner$ 'D printer and 3D printing news 'Retrieved from http://wwwr'ders‘org/3d-printer/how-to -build-3d-printer'html

30.Leger, S، S، ( April 2011)، rd printing : rapid prototyping، Desert Code Camp Retrieved july 2013, from http:// www‘slideshare‘net/jstleger/3d-printing -overview

31. How to $3 \mathrm{~d}$ print - beginner s guide to $3 \mathrm{~d}$ printing) 'May 26, 2014) ${ }^{\Upsilon}$ 'D Printer Plans Retrieved aug 2014, from http://3d printerplans،info/how-to-3dprint-beginners-guide-to-3d-printing/

32.Bell, C، ( September 3, 2014)، Maintaining and Troubleshooting Your 3D Printer (1 ed`)، New York Apress access، $\left.\Lambda_{-}\right) \cdot p$ academic library [ ACRL's TechConnect blog] 'Retrieved from http:// acrl‘ala‘org/techconnect/?p=1403

9. Britton, $L$ ( $(Y \cdot 1 Y)$ ) The makings of maker spaces, part 1: space for creation, not just consumption” "Library Journal, 137 p 20 ،

10.Fisher, E) 'November 28 2012, may) ، Makerspaces Move into A cademic Libraries [ ACRL's TechConnect blog] ، Retrieved from http://acrl‘ala‘org/ techconnect $/ \mathrm{p}=2340$

11. Lisa Kurt , T، C، Op،Cit ,

12.Gutsche, B، Op،Cit ،

13.Gallant, R ،Op، ‘Cit

14.Fisher, E ‘Op`Cit

15.Maxey, K، ( September 03, 2013 )، The history of $3 \mathrm{~d}$ printing، $\mathrm{r} \mathrm{D}$ printer and 3D printing news، Retrieved from http:// www r'ders‘org/3d-printing/3d-printinghistory ‘html

16.Hart, B) ‘Mar 11, 2014) ‘Will 3d printing change the world? 'Laissez Faire Today 'Retrieved from http:// 1fb،rg/will-3-d-printing-change-theworld/

17.Maxey, K، Op‘Cit

18. Gutsche, B، Op،Cit

19.Weinberg, M) ‘april 2011) r d printing : bits to atoms ‘Public Knowledge ، Retrieved from https://www‘publicknowledge،org/issues/3d-printing

20.Berman, B، $(r \cdot 1 r)$ ) r-D printing: The new industrial revolution 'Business Horizons, 55, $156 \mathrm{p}$ 'Retrieved from www'scienc-edirect‘com

21.The implication of $3 \mathrm{~d}$ printing) (Oct 
43.Price compare - 3D printing materials Filament، $(r \cdot 1 \leqslant)$ rD printer and 3D printing news، Retrieved from http:// wwwr`ders‘org/pricecompare

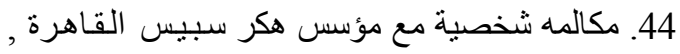

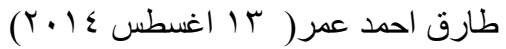

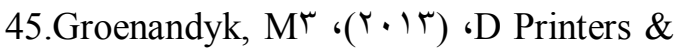
Maker Spaces what happenning to your library? public library news Retrieved sebtember, 2014, from http://www publi - clibrariesnews'com/practitioners/3dprinters-and-maker-spaces-inlibraries/2644-2

46.Tara Bradya, C، S‘, Ayah Nuriddina, Walter Rodgersa \& Mega Subramaniama ‘( Y. nov 2014)، MakeAbility: Creating Accessible Makerspace Events in a Public Library، Public Library Quarterly, 33(4), pp 333-335،

47.Britton, L، Op،Cit, pp $21-22$

48. Good, T) ‘February 6, 2013) ، Manufactu-ring Makerspaces american libraries magazine 'Retrieved from http://www'americanlibrariesmagazine،org/article/manufacturingmakerspaces

49.Learning Labs In Libraries And Museums (2013) 'Retrieved aug, 2014, from http://www،imls‘gov/recipients/ default‘aspx

50. gcooper، (January 28, 2014)، NJ State Library and LibraryLinkNJ Partner to Launch Makerspace Projects Statewide Retrieved march 2014, from http:// www'njstatelib‘org/media/press releases/pr-makerspaces/

51.Huson, Dr $(r \cdot 1 r)$ (D and Rapid Prototyping Research Retrieved sep, 2014, from http://uwerac‘uk/sca/ research/cfpr/research/3D/index ‘html
33. Weinberg, M) ‘November 10, 2010) 'It will be awesome if they don't screw it up : $3 \mathrm{~d}$ printing intellectual property and the Fight Over the Next Great Disruptive Technology 'Retrieved from https://www'publicknowledge‘org/files/ docs/3DPrintingPaperPublicKnowledge ‘pdf

34. Lisa Kurt , T، C، Op،Cit

35.Windsor, L) ‘April, 2012) 'High School Makerspace Tools \& Materials , p 30 ، San Francisco: Maker Education ، Retrieved from http://spaces‘makerspace/wp-content/uploads/2012/04/

hsmakerspacetoolsmaterials-201204،pdf

36. Lisa Kurt , T، C، Op‘Cit

37.Berman, B، Op‘Cit, $156 \mathrm{p}$

38.Mayard, A) ‘April 2, 2013)^ ‘ Hackerspaces Changing the Arab World Retrieved feb 2014, from http:// www'wa mdarcom/2013/04/9-hackerspaces-changing-the-arab-world

39.Arabic Hakcerspaces، Retrieved jan 2015, from http://saharalabs‘org/arabichackerspaces/ https://www'goog1 e،com/maps/d/viewer?mid=zwTWlEto3yM·kWEh8ZjX-k0aU\&hl=en_US

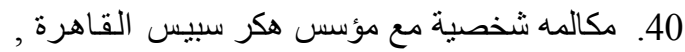

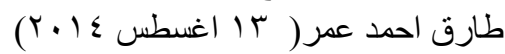

41.farkas, M، (January 31, 2012)، Bringing digital creation technologies to libraries ، american libraries magazine، Retrieved from http://www،americanlibrariesmagazine‘org/article/providing-tools

42.Price compare - 3D printers price comparer $6(Y \cdot \mid \varepsilon)$,D printer and 3D printing news 'Retrieved from http:// w w wr`d e r s‘org/pricecompare/3dprinters/ 


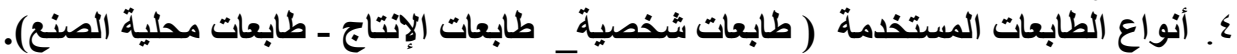

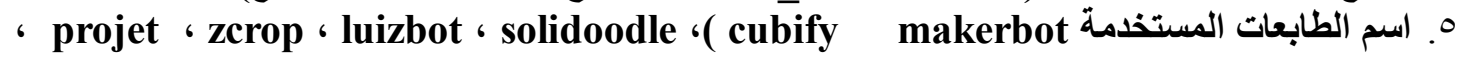
Lixpen ) ، (reprap

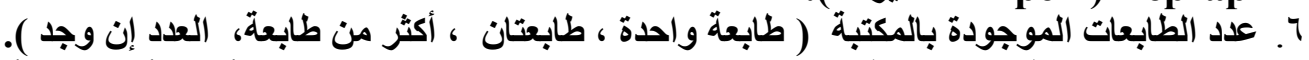

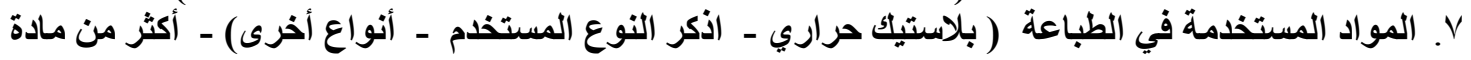
- غل غير محدد ). ^. الألوان المستخدمة ( أبيض و أسود فقط ــ الوان متعددة - الوان محدده ).

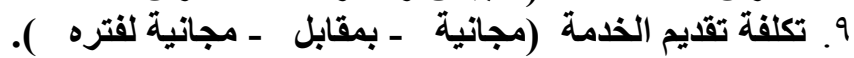

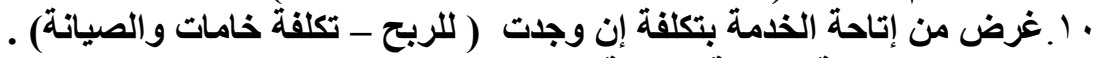

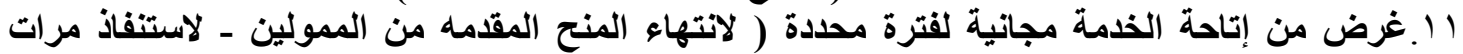

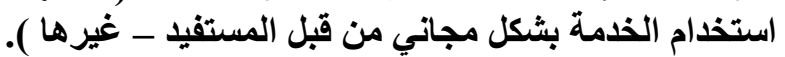

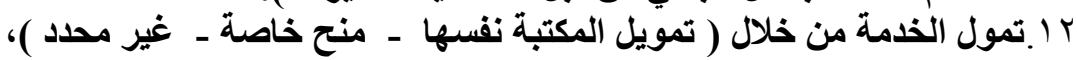

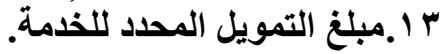

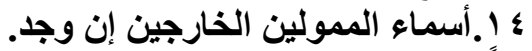

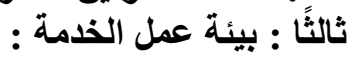

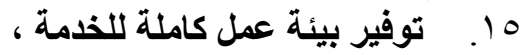

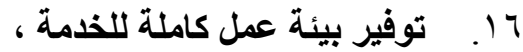

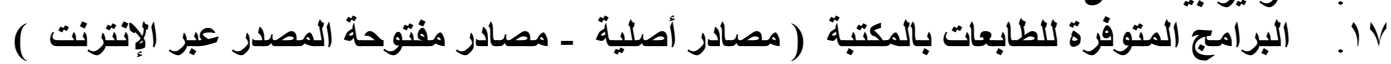

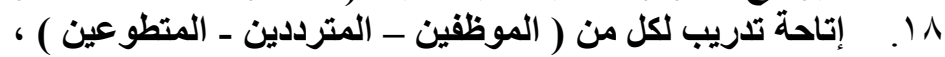

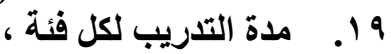

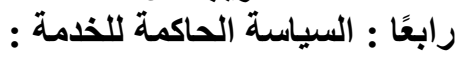

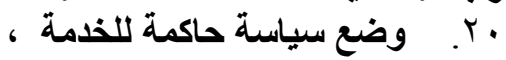

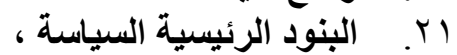

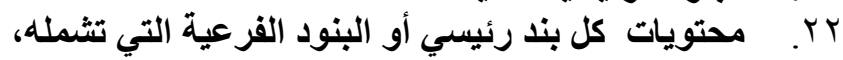
rrr.

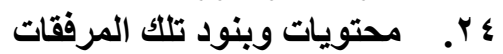

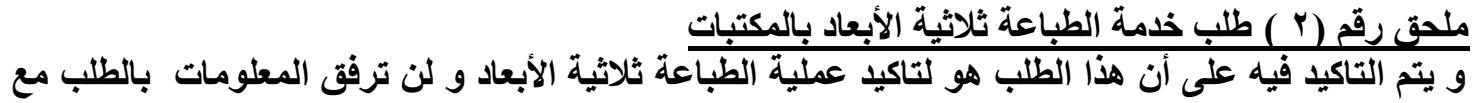

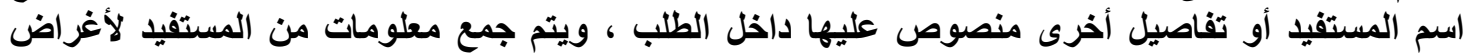

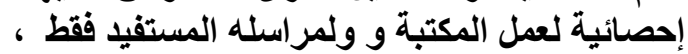
رقم تليفون إمبهة

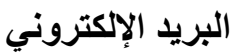
الاسم .......

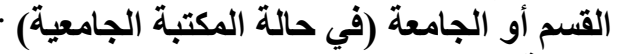

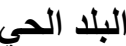
القسم أو الجامعة (في حالة المكتبة الجامعية) - معلومات عن الملف المطلوب طباعته الجئه :

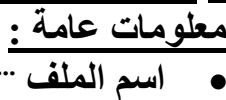




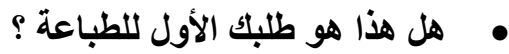

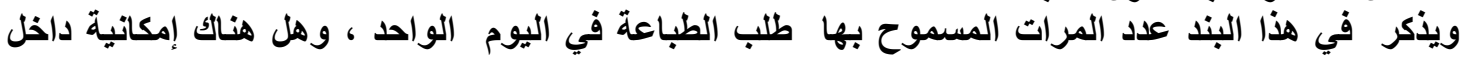

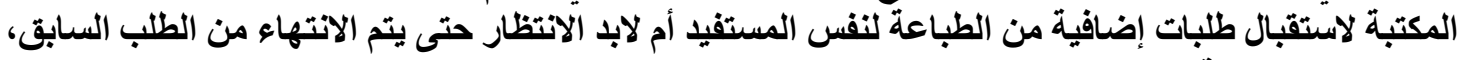

$$
\text { الارتفاع }
$$$$
\text { المقاييس والصيفة لاستيال }
$$

يفضل ذكر الحد الأقصي لكل منهم وفقًا لمواصفات الأجهزة المتوفرة لايهر.

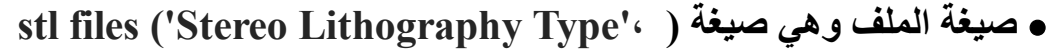

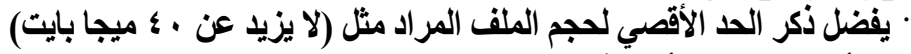

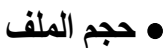

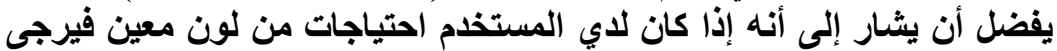

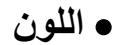

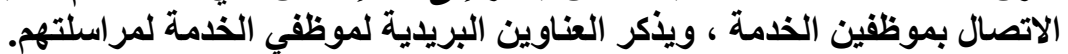

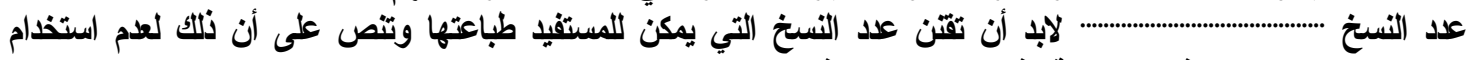

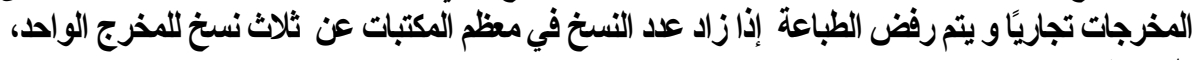

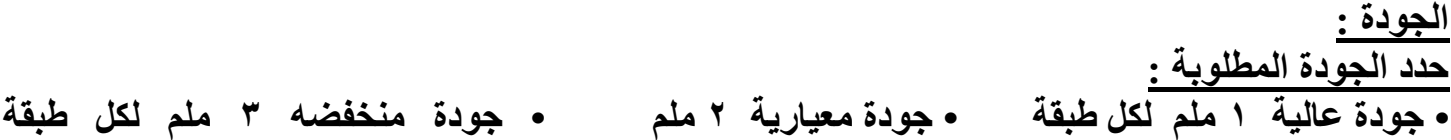

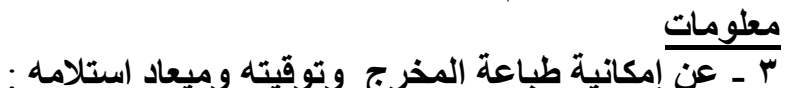

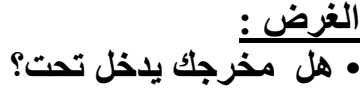

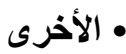

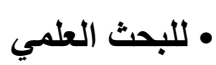
• مشروع بحثي للاراسة

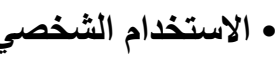

إذن إمكانية مشاركة المكتبة للملف والصور داخل الملف الخاص بالمستفيد مع الجميع؟ نعم ............................. في حالة تقديم الطباعة من خلال الموظفين:

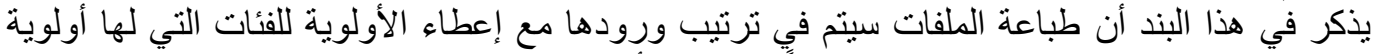

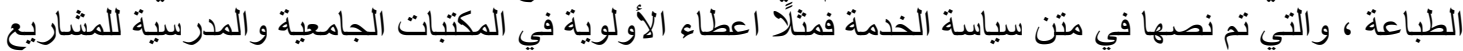

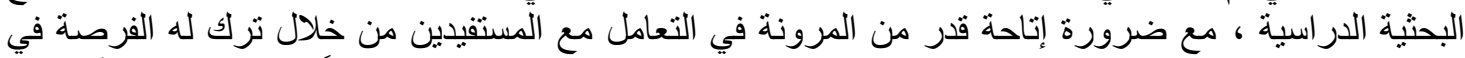

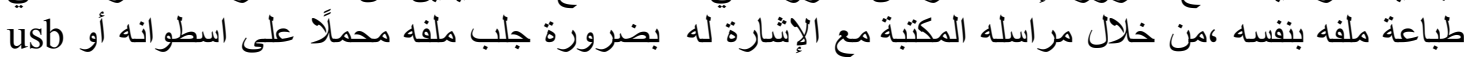

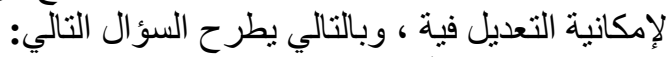

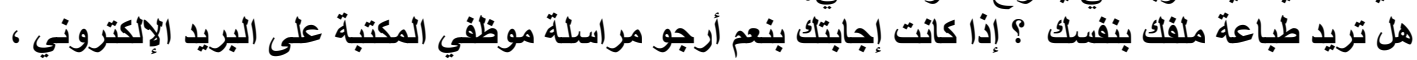

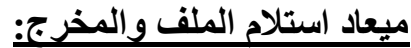

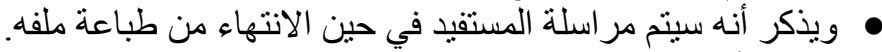

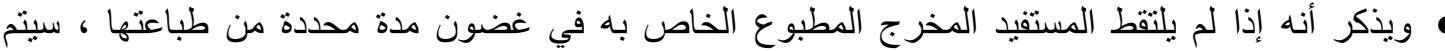

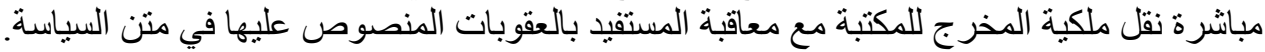

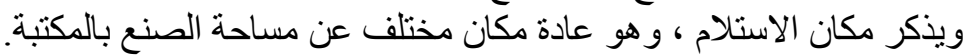

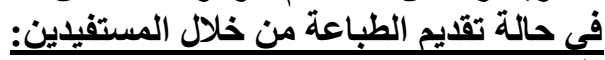

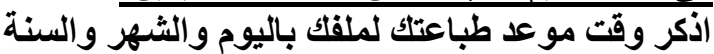

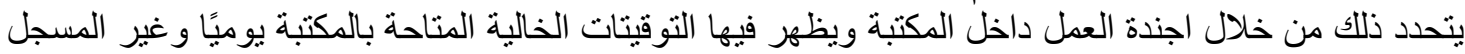

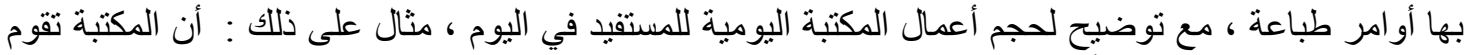

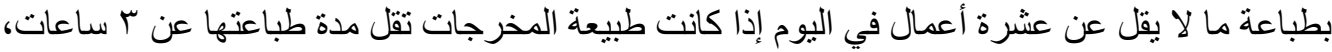

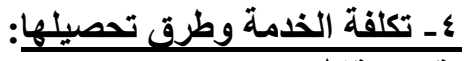

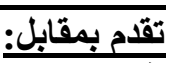

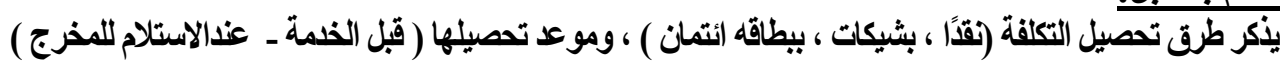


ويذكر هذاً البند في حالة طلب أكثر من أمر طباعة في اليوم الواحد في المكتبات التي تحدد مجانية الطباعة وفقًا

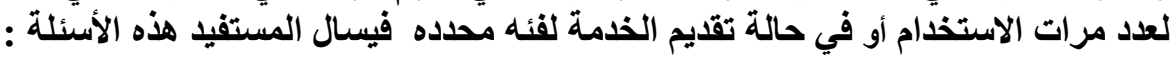

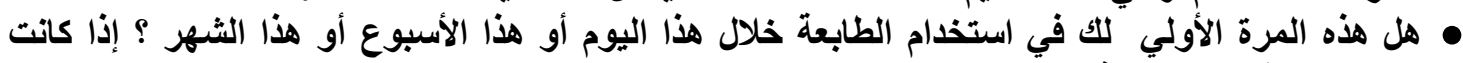

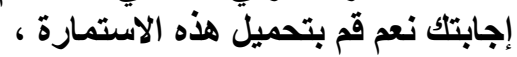
إذا كانت الخدمة تقدم لطملاب أو لفئة معينة مجانية دون غيرة هم ، يتم الإشارة إلى ضرورة تعبئة الإستمارة

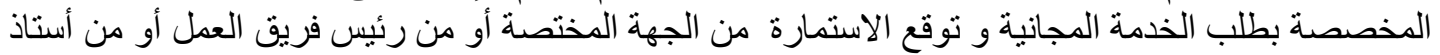

إذا كانت اجابتك بلا توجه لافع الرسوم.

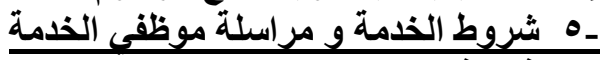

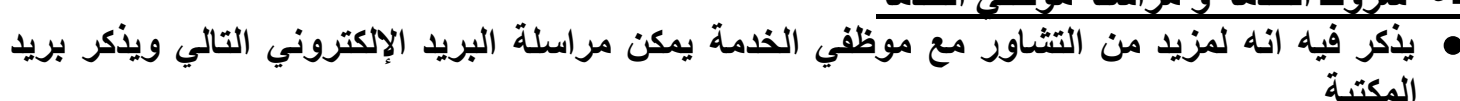

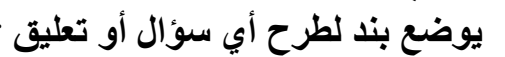

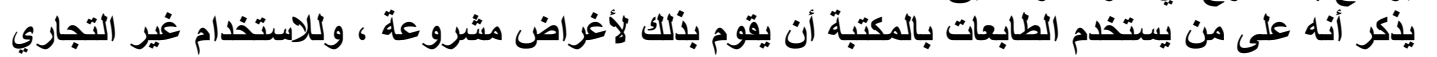

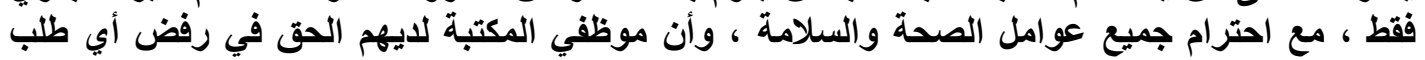

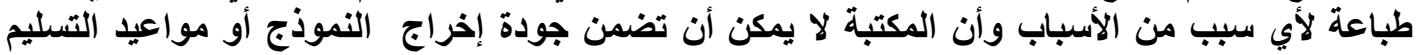

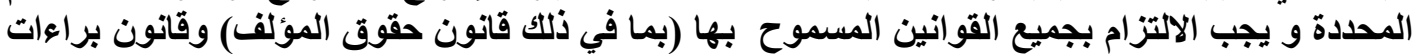

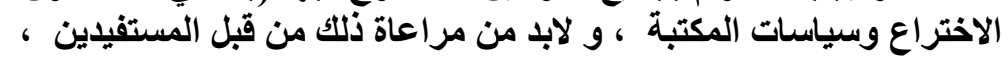

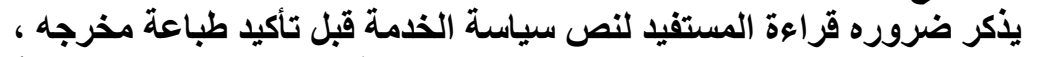

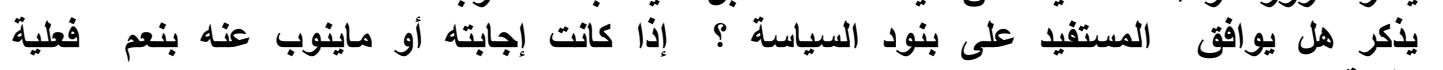

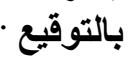
التوقيع

ملحق رقم () أسماء المكتبات في العالم التي تقدم خدمة الطباعة ثلاثية الأبعاد

\begin{tabular}{|c|c|c|c|}
\hline \multirow{3}{*}{ Australia } & 1- City of Adelaide Library Service & \multicolumn{2}{|c|}{ 2- Sunshine Coast Libraries } \\
\hline & 3- Lake macquarie city library & \multicolumn{2}{|c|}{ 4- University of Melbourne } \\
\hline & \multicolumn{3}{|l|}{ 5- Western australia public library } \\
\hline \multirow{7}{*}{ Canada } & 6- Abingdon Library & \multicolumn{2}{|c|}{ 7-The University of Waterloo } \\
\hline & 8- Brantford Public Library & \multicolumn{2}{|c|}{ 9-TheColchester-East Hants Public Library } \\
\hline & $\begin{array}{l}\text { 10- Carleton University - Canada's Capital } \\
\text { University }\end{array}$ & \multicolumn{2}{|c|}{$\begin{array}{l}\text { 11- university of prince Edward Robertson } \\
\text { Libraryisland }\end{array}$} \\
\hline & 12- Dalhousie University Libraries & \multicolumn{2}{|c|}{ 13- Windsor Public Library of Ontario } \\
\hline & 14- Halifax Public Libraries & \multicolumn{2}{|c|}{ 15- Edmonton Public Library } \\
\hline & 16-Nova Scotia Public Libraries & \multicolumn{2}{|c|}{ 17-Innisfil Public Library } \\
\hline & \multicolumn{3}{|l|}{ 18- ottawa public library } \\
\hline China & 19-Lee Wee Nam Library & Finland & 20- Helsinki city library \\
\hline France & \multicolumn{3}{|l|}{ 21- Mediatheque Louis Aragon demartigues } \\
\hline Germany & \multicolumn{3}{|l|}{ 22- Cologne Public Library } \\
\hline Greece & \multicolumn{3}{|c|}{ 23- David C Burrow Elementary School Media Centera } \\
\hline Norway & \multicolumn{3}{|c|}{ 24.Oslo public library } \\
\hline Singapore & \multicolumn{3}{|l|}{ 25- Serangoon public library } \\
\hline \multirow{2}{*}{ United Kingdom } & 26.Brighton Jubilee Library & \multicolumn{2}{|c|}{ 27.The University of the West of England } \\
\hline & 28.Gloucester County Library System & \multicolumn{2}{|c|}{ 29.Gateshead Library } \\
\hline United States & 30.Allen County Public Library & \multicolumn{2}{|c|}{ 31.Chattanooga public library } \\
\hline
\end{tabular}




\begin{tabular}{|c|c|c|}
\hline & 32.Alum rock branchlibrary & 33.Cleveland Public Library's \\
\hline & 34.American Universityin Washington, DC & 35.Columbia University libraries \\
\hline & 36.Ann arbor district library & 37.- Columbus Metropolitan Library \\
\hline & 38.Anythink Libraries The Studio & 39.Cornell university \\
\hline & 40.Arbutus public library & $\begin{array}{l}\text { 41.Creation Station - Caldwell College } \\
\text { Library }\end{array}$ \\
\hline & 42.Barrington Area Library's & 43.Danbury public library \\
\hline & 44.Boisepublic library & $\begin{array}{l}\text { 45.-DeLaMare Science \& Engineering } \\
\text { Library }\end{array}$ \\
\hline & 46.Boxford town library & 47.Denver Public Library \\
\hline & 48.- Brookfield public library & 49.Broward County Library \\
\hline & 50.Caldwell Public Library & 51. Livingston Parish Library \\
\hline & 52. Detroit Public Library- & 53.Louisville free public library \\
\hline & 54. dover public library & 55. Loveland public library \\
\hline & 56. Drake Memorial Library & 57. Madison Public Library \\
\hline & 58. Duxbury free library & 59. Manasquan High School Media \\
\hline & 60 . East baton rouge library & $\begin{array}{l}\text { 61.Martin Luther King Jr Memorial li- } \\
\text { brary }\end{array}$ \\
\hline & 62.East Brunswick Public Library & 63. Merrick library \\
\hline & 64. Fayetteville Free Library- & 65. Miami University Libraries \\
\hline & 66. Frisco Public Library's & 67.Middle Tennessee State University \\
\hline & 68.Glen Ellyn Public Library & 69.Missoula public library \\
\hline & 70.Gould academy - sanborn family library & 71.Morris library \\
\hline & 72. Great river regional library & 73.Mount Laurel Public Library \\
\hline \multirow{19}{*}{ United States } & 74. Gwinnett County Public Library & 75.Muncie public library \\
\hline & 76. Harvard university & 77.Nampa public library \\
\hline & 78. Hillsdale Public Library & 79. Nashville public library foundation \\
\hline & 80. Hoboken Public Library & 81.Nevada public library \\
\hline & 82. howard county library & 83.New Brunswick Public Library \\
\hline & 84. Idaho Libraries & 85.New Canaan Library \\
\hline & $\begin{array}{l}\text { 86.J Willard Marriott Library at the University } \\
\text { of Utah }\end{array}$ & 87.New York Public Library- \\
\hline & 88.Johnson County Public Library & 89.Northbrook Public Library \\
\hline & 90. keene public library & $\begin{array}{l}\text { 91.Las Vegas-Clark County Library Dis- } \\
\text { trict }\end{array}$ \\
\hline & 92.Lange library Miami valley school & 93.Skokie Public Library in Illinois \\
\hline & 94.Northern Onondaga Public Library- & 95. Somerset County Public Library \\
\hline & 96.Oak Park Public Library- & 97.South Butler Community Library \\
\hline & 98. Old Bridge Public Library & 99.St Louis Public Library \\
\hline & 100. Orlando public library & 101.St Paul Public Library \\
\hline & 102. Parsippany-Troy Hills Public Library & 103.Stanford University \\
\hline & 104. Patchogue-Medford Library & 105.State university of new Oswego \\
\hline & 106. Paul smith college & 107.Tacoma Public Library \\
\hline & $\begin{array}{l}\text { 108.Pendergrass Agriculture and Veterinary } \\
\text { Medicine Library }\end{array}$ & 109.The Bethlehem Public Library \\
\hline & 110.Pima County Public Library & 111. The central library in Charlottesville \\
\hline
\end{tabular}




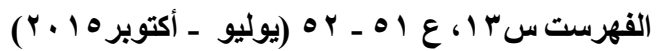

خدمة الطباعة ثلاثية الأبعاد في المكتبات حول العالم

\begin{tabular}{|c|c|}
\hline 112.Piscataway public library & 113.-The Great Falls Public Library \\
\hline 114.Plainfield Public Library & 115.The University of Mary Washington \\
\hline 116.Poughkeepsie Public Library District & 117.The University of Michigan- \\
\hline 118.rangeview library district & 119.The University of Victoria \\
\hline $\begin{array}{l}\text { 120.Reston regional library atFairfax County Public } \\
\text { Library }\end{array}$ & 121.Toronto Public Library \\
\hline 122.Robert hoag rawlings library & 123. Town of vail public library \\
\hline 124.Rochester Public Library & 125.Trumbull library \\
\hline 126.- Rutgers University Libraries & 127. University of California \\
\hline 128. Sacramento public library & 129. University of Florida \\
\hline 130.Saginaw library & 131.Schreiner University \\
\hline 132.Salinas Public Library- & 133.Seminole Community Library \\
\hline 134.San Francisco Public Library & 135.Free Library of Philadelphia MakerJawn \\
\hline 136. Valdosta State University- & 137.Hampton Library in Bridgehampton \\
\hline 138. Valley Library Oregon State University & 139.Lomira QuadGraphics Community Library \\
\hline 140.Warwick Public Library & 141.Matteson Public Library \\
\hline 142.Westport Public Library's upcoming & 143.Middletown Free Library \\
\hline 144.Delaware Libraries & 145.Multnomah County Library \\
\hline 146. Atlantic City Public Library & 147.North Carolina State University \\
\hline 148.Calcasieu parish public library & 149. Northeastern UniversityLibraries \\
\hline 150.Carnegie Library of Pittsburgh & 151.Northlake Public Library Districtl \\
\hline 152.Chicago Public Library & 153.Phoenix Public Library \\
\hline 154.Cranstonpublic Library & 155.Sauk City Public Library \\
\hline 156.District of Columbia Public Library system & 157.Sunnyvale Public Library \\
\hline 158.DuPont-Ball Library - at Stetson University & 159.The University of Alabama \\
\hline $\begin{array}{l}\text { 160.The Public Library of Cincinnati and Hamilton } \\
\text { County }\end{array}$ & 161.Urbana Free Library \\
\hline 162.University of Maryland & 163.Van Meter Public Library \\
\hline
\end{tabular}

